Pacific Northwest National Laboratory

Operated by Battelle for the U.S. Department of Energy

\section{0-D Area In Situ Redox \\ Treatability Test for Chromate- \\ Contaminated Groúndwater: \\ FY 1998 Year-End Report}

M. D. Williams

RECEIVED
APR 26999

J.E. Szecsody

J.S. Fruchter

C. R. Cole

Q. 51

March 1999

Prepared for the U.S.Department of Energy

under Contract DE-AC06-76RLO 1830 


\section{DISCLAIMER}

This report was prepared as an account of work sponsored by an agency of the United States Government. Neither the United States Government nor any agency. thereof, nor Battelle Memorial Institute, nor any of their employees, makes any warranty, express or implied, or assumes any legal liability or responsibility for the accuracy, completeness, or usefulness of any information, apparatus, product, or process disclosed, or represents that its use would not infringe privately owned rights. Reference herein to any specific commercial products process, or service by trade name, trademark, manufacturer; or otherwise does not necessarily constitute or imply its endorsement; recommendation, or favoring by the United States Government or any agency thereof, or Battelle Memorial Institute. The views and opinions of authors expressed herein do not necessarily state or reflect those of the United States Government or any agency thereof.

\section{PACIFIC NORTHWEST NATIONAL LABORATORY operated by \\ BATIELLE \\ for the \\ UNTTED STATES DEPARTMENT OF ENERGY} under Cóntract $D E-A C O$ C-76RLO 1830

Printed in the United States of America

A vailable to DOE and DOE contractors from the. Office of Scientific and Technical Information, 1.O. Box 62,0ak Ridge, TN 37831; prices available from (615) $576-8401$.

Available to the public from the National Technical Information Service, US. Department of Commerce, 5285 Port Royal Rd., Springfield, VA 22161 


\section{DISCLAIMER}

Portions of this document may be illegible in electronic image products. Images are produced from the best available original document. 


\title{
100-D Area In Situ Redox Treatability Test for Chromate-Contaminated Groundwater: FY 1998 Year-End Report
}

\author{
M. D. Williams \\ V.R. Vermeul \\ J. E. Szecsody \\ J. S. Fruchter \\ C. R. Cole
}

March 1999

Prepared for

the U.S. Department of Energy under Contract DE-AC06-76RLO 1830

Pacific Northwest National Laboratory

Richland, Washington 99352 
$-\ldots$ 


\section{Summary}

A treatability test was conducted for the In Situ Redox Manipulation (ISRM) technology at the U. S. Department of Energy's Hanford, Washington 100D Area. The target contaminant was dissolved chromate $[\mathrm{Cr}(\mathrm{VD})]$ in groundwater. The ISRM technology involves creating a permeable subsurface treatment zone to reduce mobile chromate in groundwater to an insoluble form. The ISRM permeable treatment zone is created by reducing ferric iron [Fe(III)] to ferrous iron [Fe(II)] within the aquifer sediments. This is accomplished by injecting aqueous sodium dithionite into the aquifer and withdrawing the reaction products.

The goal of the treatability test was to create a linear ISRM barrier by injecting sodium dithionite into five wells. Well installation and site characterization activities began in the spring of 1997. The first dithionite injection took place in September 1997. The results of this first injection were monitored through the spring of 1998; the remaining four dithionite injections were carried out in May through July of 1998.

These five injections created a reduced zone in the Hanford unconfined aquifer 150 feet in length (perpendicular to groundwater flow) by 50 feet wide. The reduced zone extended over the thickness of the unconfined zone, which is approximately 15 feet. Analysis of recent groundwater sampling events shows that the concentrations of chromate $[\mathrm{Cr}(\mathrm{VI})]$ in groundwater in the reduced zone have been decreased from starting concentrations of approximately $900 \mathrm{ppb}$ to below analytical detection limits $(<7 \mathrm{ppb})$. Chromate concentrations are also declining in some downgradient monitoring wells.

Laboratory analysis of iron in the soil indicates that the barrier should remain in place for approximately 20 to 25 years. These measurements will be confirmed by analysis of sediment cores in FY 1999. 


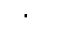




\section{Acknowledgments}

This work was prepared with the support of the following contributors:

Headquarters: $\quad$ Office of Science and Technology

Skip Chamberlain

Focus Area/Program: Subsurface Contaminants Focus Area

James Wright

Operations Office: Richland Operations Office

Science and Technology Programs Division

John P. Neath, Technical Program Officer

Contractor: $\quad$ Pacific Northwest National Laboratory

Environmental Science and Technology

Environmental Technology Division

Rod K. Quinn, Manager 



\section{Contents}

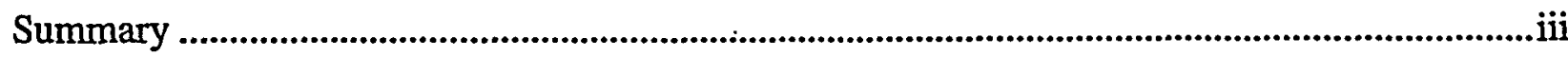

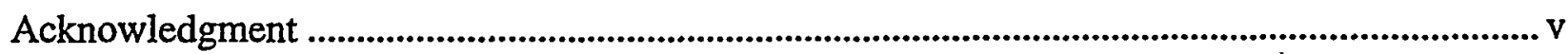

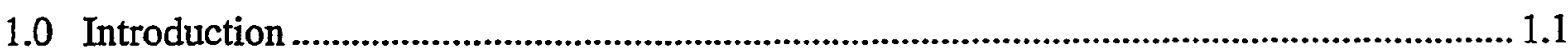

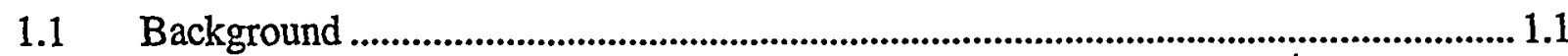

1.2 Technology Description .............................................................................................. 1.4

1.3 Test Summary ………....................................................................................................... 1.8

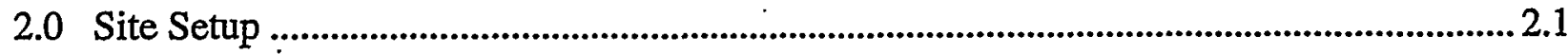

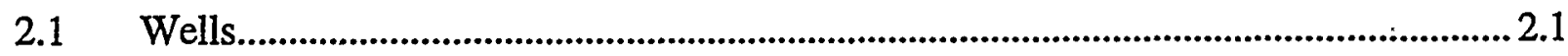

2.2. Columbia River Substrate Pore Water Sampling Tubes .................................................... 2.5

2.3 Tanks .............................................................................................................................. 2.5

$2.4 \quad$ Injection and Withdrawal Pumps ...................................................................................... 2.6

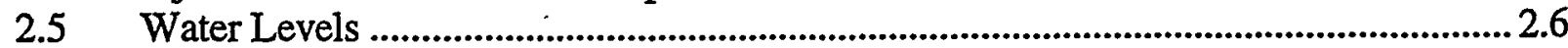

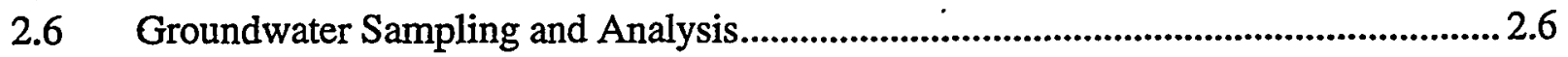

3.0 Site Characterization Results ............................................................................................... 3.1

3.1 Hydrogeologic Setting....................................................................................................

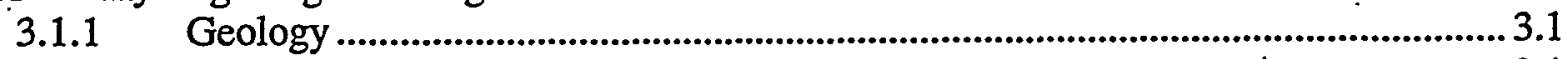

3.1.2 Physical Properties of Sediment Samples ............................................................... 3.1

$3.2 \quad$ Hydraulic Testing............................................................................................................. 3.2

3.3 Groundwater Flow Direction .......................................................................................... 3.2

3.4 Chinook Salmon Survey .............................................................................................. 3.3

3.5 Baseline Aqueous Geochemistry ....................................................................................... 3.3

3.6 Columbia River Substrate Pore Water Samplers ................................................................. 3.4

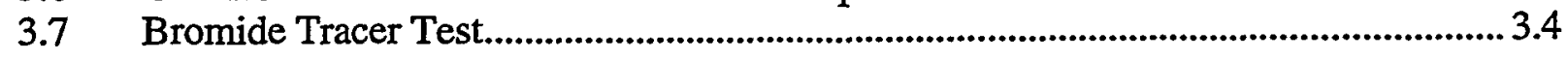

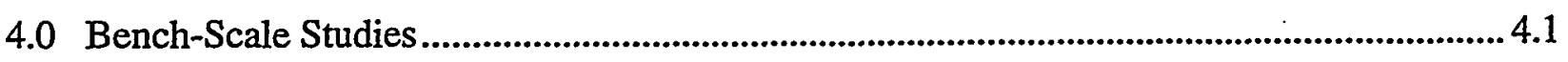

4.1 Iron Geochemistry During Reduction and Oxidation ....................................................... 4.1

4.2 Batch and Column Experimental Methods ......................................................................... 4.3

4.3 Sediment Reduction Results ........................................................................................ 4.4

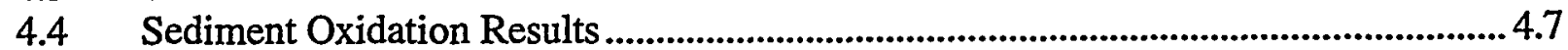

4.5 Mineralogical Changes During Dithionite Treatment........................................................ 4.7

4.6 Immobilization of Chromate ...................................................................................... 4.9

4.7 Trace Metals Mobilization ....................................................................................... 4.10

5.0 Emplacement Process................................................................................................. 5.1

5.1 Emplacement Strategy........................................................................................... 5.1

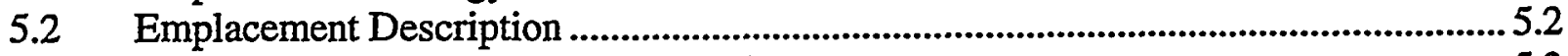

5.3 D4-7 Dithionite Injection/Withdrawal Test ...................................................................... 5.2

5.3.1 Injection Stage........................................................................................................ 5.2

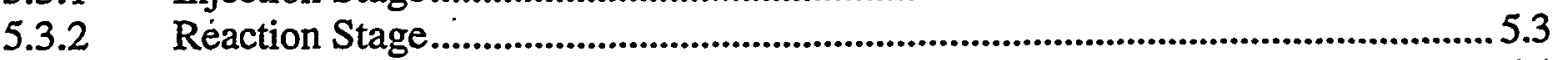

5.3.3 Withdrawal Stage ................................................................................................ 5.4

5.4 Additional Dithionite Injection/Withdrawal Tests ............................................................. 5.6

6.0 Preliminary Performance Results.................................................................................... 6.1 
6.1 Groundwater Quality

6.2 Columbia River Porewater Sampling Tubes ....................................................................... 6.4

6.3 Estimated Barrier Longevity ........................................................................................... 6.9

7.0 Planned FY 1999 Activities ......................................................................................... 7.1

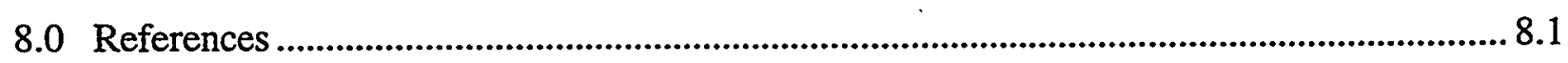

Appendix A: Well Summary Diagrams ................................................................................ A.1

Appendix B: Comparison of Pre- and Post-Injection Results........................................................

Appendix C: Columbia River Substrate Porewater Sampling Tube Results ..............................C.1

Appendix D: Bromide Tracer Test Breakthrough Curves ........................................................ D.1

Appendix E: D4-7 Dithionite Injection/Withdrawal Test Breakthrough Curves.........................E.1 


\section{Figures}

1.1 Location of the In Situ Redox Manipulation 100-H Area Proof-of-Principle Test ............... 1.2

1.2. 100-D Area $\mathrm{Cr}^{6+} \mathrm{Groundwater}$ Concentrations for 1997 ........................................................ 1.3

1.3 Geologic Cross-Section and $\mathrm{CR}^{+6}$ Concentrations on West Side of 100-D Area.................. 1.5

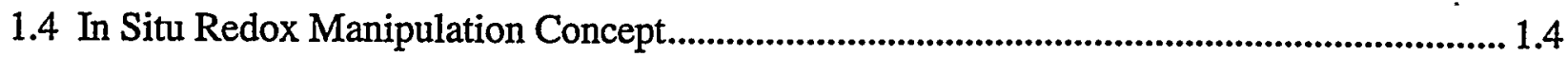

1.5 Conceptual Diagram of In Șitu Redox Manipulation Permeable Treatment Barrier............. 1.6

1.6 Emplacement Strategy and Well Diagram for 100-D Area ISRM Treatability Test.............. 1.7

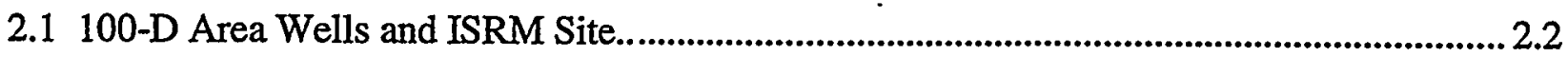

2.2 100-D Area ISRM Wells from Survey Locations................................................................ 2.3

2.3 Photographs of Setup and Equipment at 100-D Area ISRM Treatability Test Site............... 2.4

3.1 Groundwater Flow Directions and Magnitudes Measured at 100-D Area ISRM Site........... 3.4

3.2 Baseline Hexavalent Chromium Concentrations at 100-D Areas ISRM Site......................... 3.9

3.3 Cross-Section of Baseline Hexavalent Chromium at 100-D Area ISRM Site..................... 3.10

3.4 Baseline Dissolved Oxygen Concentrations at the 100-D Area ISRM Site ......................... 3.11

4.1 Reduction of 100-D Sediment by a Sodium Dithionite Treatment.......................................... 4.6

4.2 Oxidation of Dithionite-Reduced Sediment by Dissolved Oxygen in Water. ........................ 4.8

4.3 1-D Column Experiment Results Showing Reduction and Immobilization of $\mathrm{Cr}(\mathrm{VI})$ Species when Hanford Sediment is Reduced ..........................................................10

5.1 Extent of Injection Mound Formed during D4-7 Dithionite ................................................5.4

6.1 Post-Emplacement Hexavalent Chromium Concentrations at the 100-D Site........................ 6.5

6.2 Cross-Section of Post-Emplacement Hexavalent Chromium at 100-D Site........................... 6.6

6.3 Post-Emplacement Dissolved Oxygen Concentrations at 100-D Site .....................................6.7

\section{Tables}

3.1 Field Parameters and Major Anions from 9/29/97 Monitoring of ISRM Site. ......................3.6

3.2 Trace Metal Analysis from 9/29/97 Monitoring of ISRM Site.............................................3.7

3.3 Average Baseline Measurements at the 100-D Area ISRM Site ...........................................3.8

3.4 Bromide Tracer Test: Br Arrival Time Summary ............................................................ 3.8

4.1 Reaction Mass and Rates from Column Experiments......................................................... 4.5

5.1 Dithionite Injection/Withdrawal Summary ..................................................................5.3

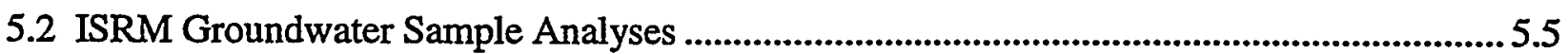

6.1 Field Parameters And Major Anions From 9/3/98 Monitoring of ISRM Site ........................ 6.2 
6.2 Trace Metal Analysis from 10/8/97 Monitoring of ISRM Site................................................. 6.3

6.3 Groundwater Measurement Summary Within the Treatment Zone......................................... 6.4

6.4 Groundwater Measurement Summary Downgradient of Treatment Zone............................. 6.4

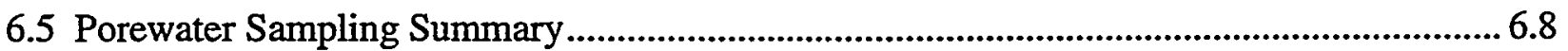




\subsection{Introduction}

This report describes the results of the site characterization, emplacement, and groundwater monitoring activities conducted for the In Situ Redox Manipulation (ISRM) Treatability Test for chromate contamination in the aquifer on the west side of 100-D Area (100-HR-3 Operable Unit) of the Hanford Site (see Figures 1.1 and 1.2). Fruchter et al. (1997) contains the Treatability Test Plan that describes the treatability test, Data Quality Objectives, permitting requirements, cultural and biological survey results, data gathering activities, and sampling/analysis plan. The objective of the 100-D Area ISRM Treatability Test is to develop performance and cost data at a pilot-scale for an assessment of this technology for treating chromate-contaminated groundwater at the Hanford Site. A smaller-scale proof-of-principle test for this technology was conducted at the 100-H Area during 1995 and described in Fruchter et al. $(1996,1998)$.

\subsection{Background}

The Hanford Site is in southeastern Washington (Figure 1.1). Hanford was established in 1943 to produce plutonium for nuclear weapons using reactors and chemical processing plants. The 100 Area of the Hanford Site is located along the Columbia River and includes nine deactivated U.S. Department of Energy (DOE) nuclear reactors used for plutonium production between 1943 and 1987. Operations at the Hanford Site are now focused on environmental restoration and waste management. In November 1989, the U.S. Environmental Protection Agency (EPA) designated the 100 Area of the Hanford Site a Superfund site and placed it on the National Priorities List because of the soil and groundwater contamination from past operation of the nuclear facilities. To organize cleanup efforts under Superfund, contaminated areas at the nine deactivated reactors were subdivided into areas called "operable units."

The 100-HR-3 Operable Unit is in the north-central part of the Hanford Site along a section of the Columbia River known as the "Hanford Reach." This operable unit includes the groundwater underlying the 100-D/DR and 100-H Reactor areas and the 600 Area in between. The 100-D/DR Area is the site of two deactivated reactors: the D Reactor, which operated from 1944 to 1967, and the DR Reactor, which operated from 1950 to 1965 . The H Reactor operated from 1949 to 1965.

During reactor operations, hexavalent chromium, or chromate, in the form of sodium dichromate $\left(\mathrm{Na}_{2} \mathrm{Cr}_{2} \mathrm{O}_{7}\right)$ was used as an anticorrosion agent in the reactor cooling water. Large volumes of reactor cooling water containing sodium dichromate and short-lived radionuclides were discharged to retaining basins for ultimate disposal in the Columbia River through outfall pipelines. Liquid wastes from other reactor operations (decontamination, water treatment, etc.) also contained significant quantities of hexavalent chromium. These wastes were discharged to the soil column at cribs, trenches, and french drains or leaked from storage facilities. Contaminant plumes in groundwater have resulted from these former waste disposal practices. Groundwater beneath the D/DR and $H$ Reactor areas is contaminated with hexavalent chromium and is flowing toward and entering into the Columbia River from the natural water-table gradient. 
100-D, DR

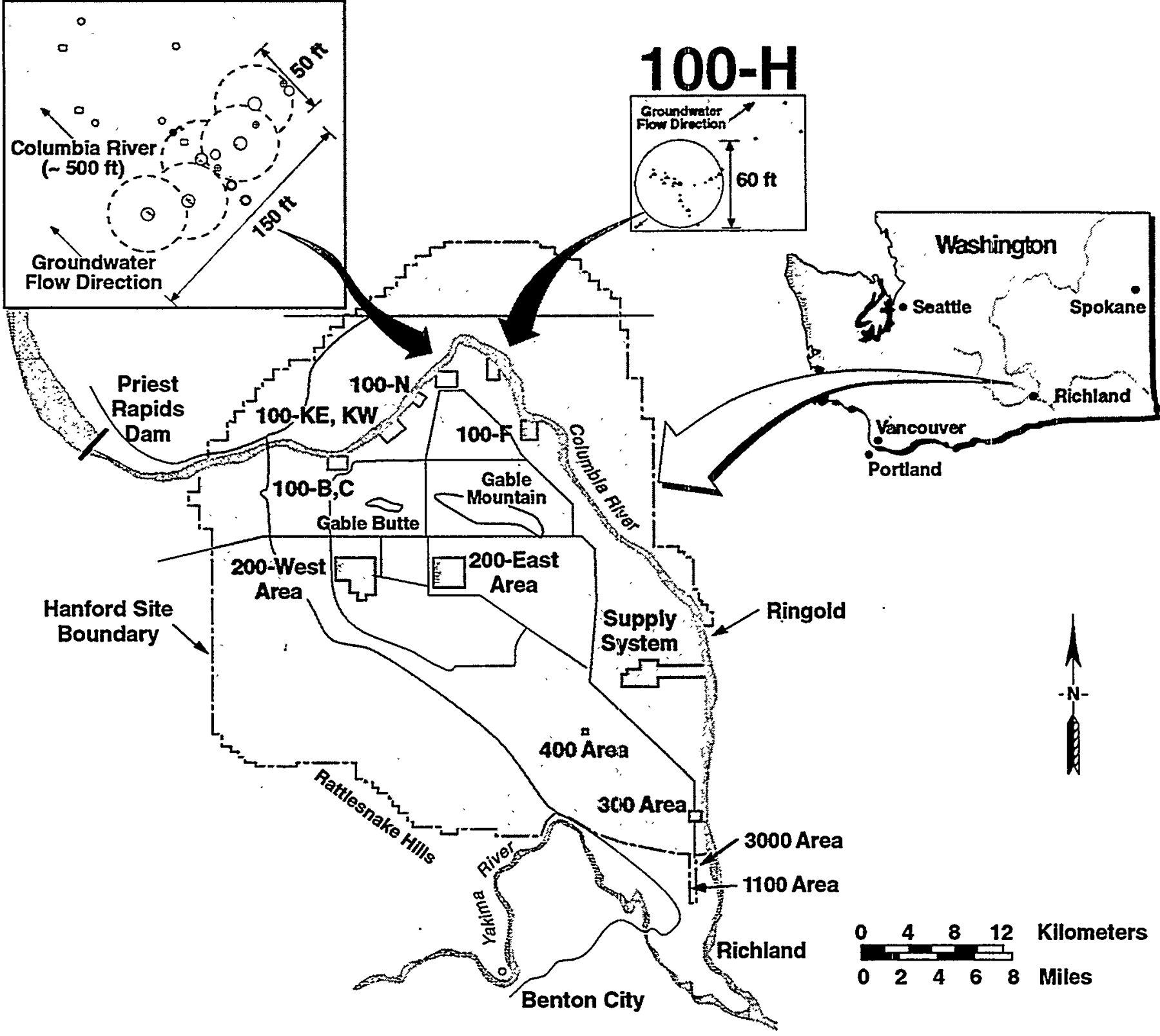

Figure 1.1. Location of the In Situ Redox Manipulation 100-H Area Proof-of-Principle Test Site and 100-D Area Treatability Test Site 


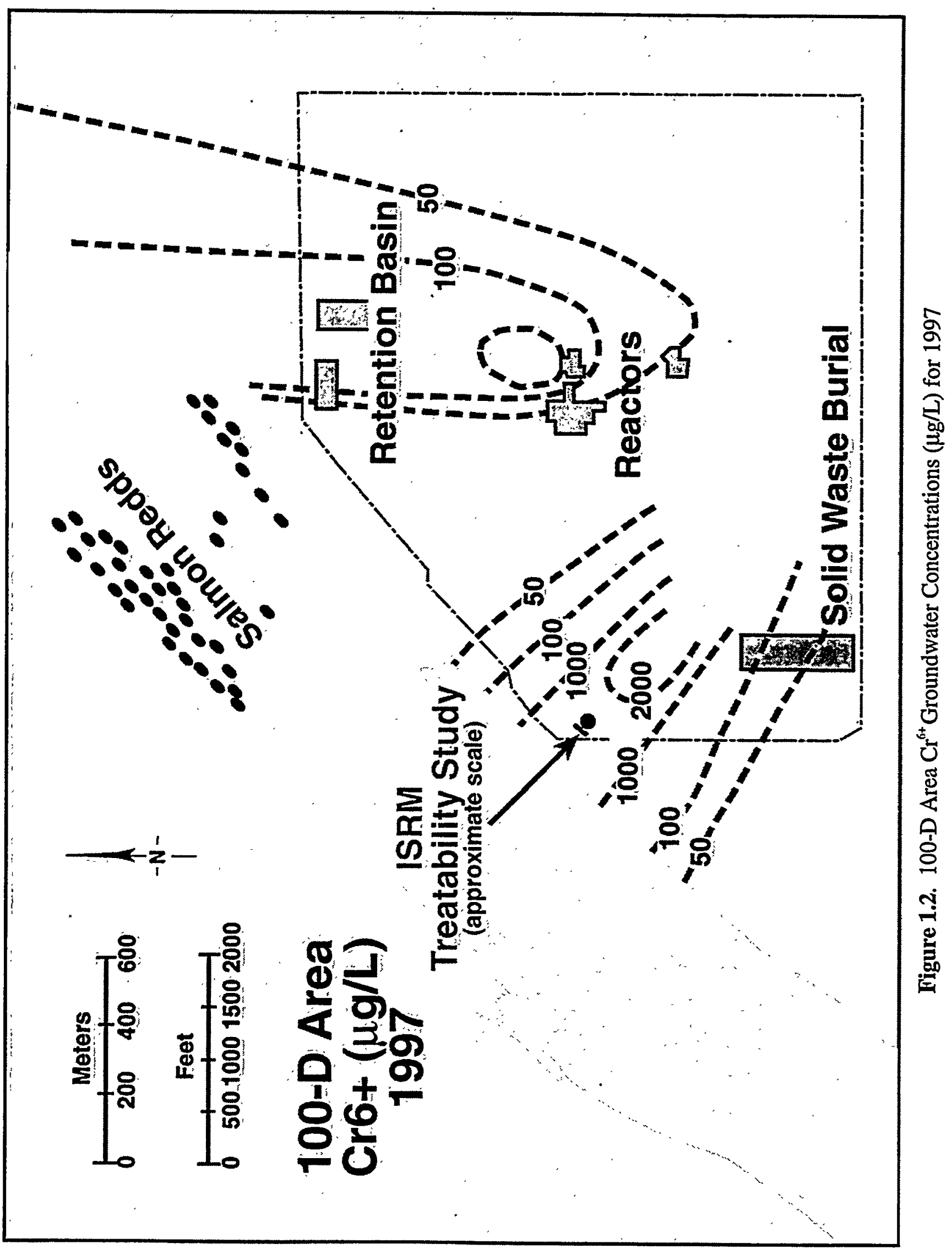


In addition to the reactor areas, high concentrations $(\sim 1,000 \mu \mathrm{g} / \mathrm{L})$ of hexavalent chromium were detected in the groundwater in the 100-HR-3 Operable Unit along the western edge of the 100D/DR Area at well 199-D4-1, which was drilled in the fall of 1996 (see Figures 1.2 and 1.3). This is the location of the ISRM Treatability Test described in this report (see Figure 1.2). Well 199-D4-1 was drilled following a characterization program that detected hexavalent chromium concentrations in excess of $600 \mu \mathrm{g} / \mathrm{L}$ in the pore waters of the Columbia River substrate along the 100-D/DR Area (Peterson et al. 1998; Hope and Peterson 1996; Connelly 1997a). The elevated hexavalent chromium concentrations detected in the pore waters of the river substrate pose a potential risk to aquatic organisms in the Columbia River. The 199-D4-1 well (which was drilled approximately $152 \mathrm{~m}(500 \mathrm{ft})$ inland from the highest concentrations measured in the river substrate pore water) helped identify groundwater as the source of the hexavalent chromium in the Columbia River substrate pore water (Connelly 1997a). Characterization activities, including four new wells drilled during the summer of 1997 (Weeks 1997; Connelly 1997b), are continuing to help define the areal extent and the original source of this groundwater plume.

The Proposed Plan for Interim Remedial Measure at the 100-HR-3 Operable Unit (DOE 1995) identified the preferred alternative for an interim remedial measure at the 100-HR-3 Operable Unit. The preferred alternative is to pump contaminated groundwater from the $100-\mathrm{HR}-3$ Operable Unit, treat it by ion exchange, and then dispose of it using upgradient injection wells to return it to the aquifer. The 100-D Area chromate "Hot Spot" near well D4-1 had not been identified at the time the interim remedial measure for the 100-HR-3 operable unit was prepared and was therefore not considered. The proposed plan also considered the possibility that alternative technologies could immobilize hexavalent chromium in the aquifer without pumping and treating. One of those technologies, ISRM, would immobilize hexavalent chromium by changing the soil and water chemistry in the aquifer and reducing the chromium to the less toxic and less mobile trivalent form. The ISRM technology promises to 1) prevent movement of hexavalent chromium to sensitive ecological receptors without creating the secondary waste associated with surface treatment technologies and 2) reduce the need for long term operation and maintenance required of pump-and-treat technologies. Thus ISRM could result in substantial cost savings over the pump-and-treat methods of groundwater plume remediation.

\subsection{Technology Description}

In Situ Redox Manipulation (ISRM) technology involves creating a permeable subsurface treatment zone to reduce mobile chromate in groundwater to an insoluble form. An unconfined aquifer is usually an oxidizing environment; therefore, most of the contaminants that are mobile in the aquifer are mobile under oxidizing conditions. If the redox potential of the aquifer can be made reducing, then a variety of contaminants could be treated (Figure 1.4a). Redox-sensitive contaminants migrating through this treatment zone would be destroyed (organic solvents) or immobilized (metals). A successful ISRM proof-of principle experiment conducted in the $100-\mathrm{H}$ Area in 1995 (Fruchter et al. 1996, 1998) demonstrated the ability to alter the redox potential of the unconfined aquifer at the Hanford Site and to remove chromate from the groundwater.

The ISRM permeable treatment zone is created by reducing the ferric iron (Fe3+) to ferrous iron $(\mathrm{Fe} 2+$ ) within the aquifer sediments. This is accomplished by injecting sodium dithionite $\left(\mathrm{Na}_{2} \mathrm{~S}_{2} \mathrm{O}_{4}\right)$ into the aquifer and withdrawing unreacted reagent and reaction products. The sodium dithionite serves as a reducing agent for iron, changing ferric iron to ferrous iron within the 


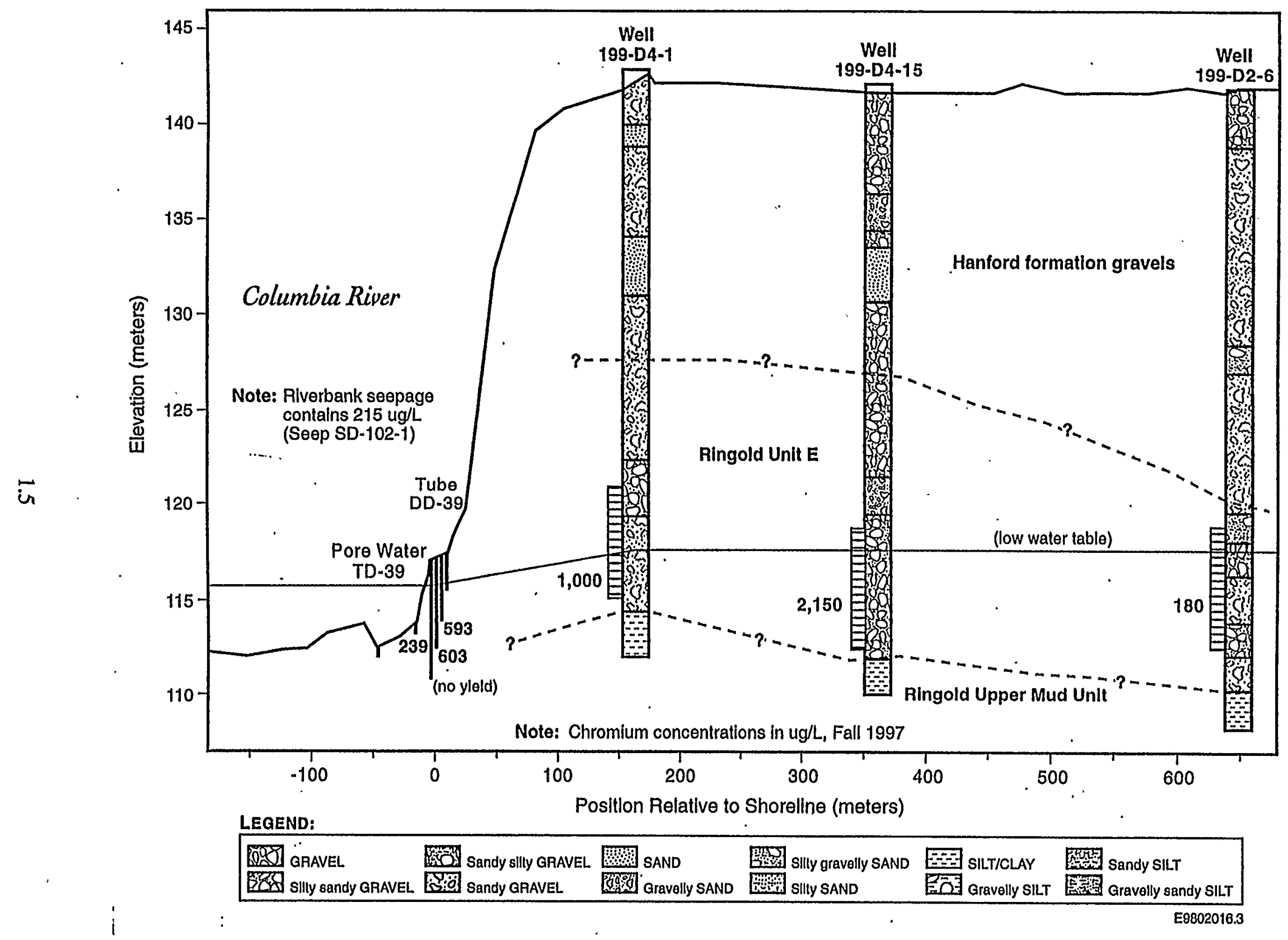

Figure 1.3. Geologic Cross-Section and Hexavalent Chromium Concentrations on the West Side of 100-D Area (Peterson et al. 1998). The ISRM Treatability Test Site is at Well 199-D4-1. 


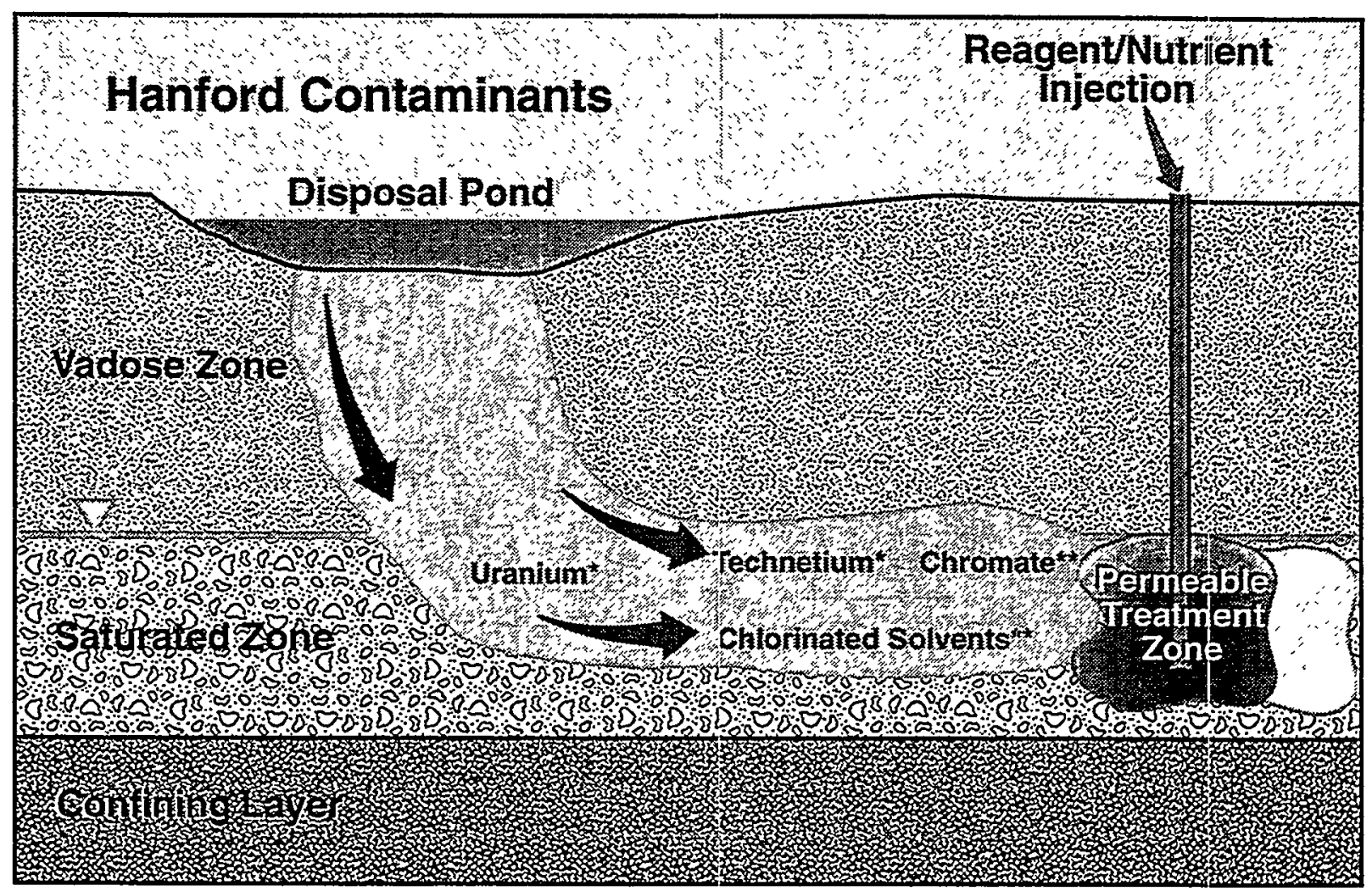

* Potential Candidate for Redox Treatment

a)

* Favorable Candidate for Redox Treatment

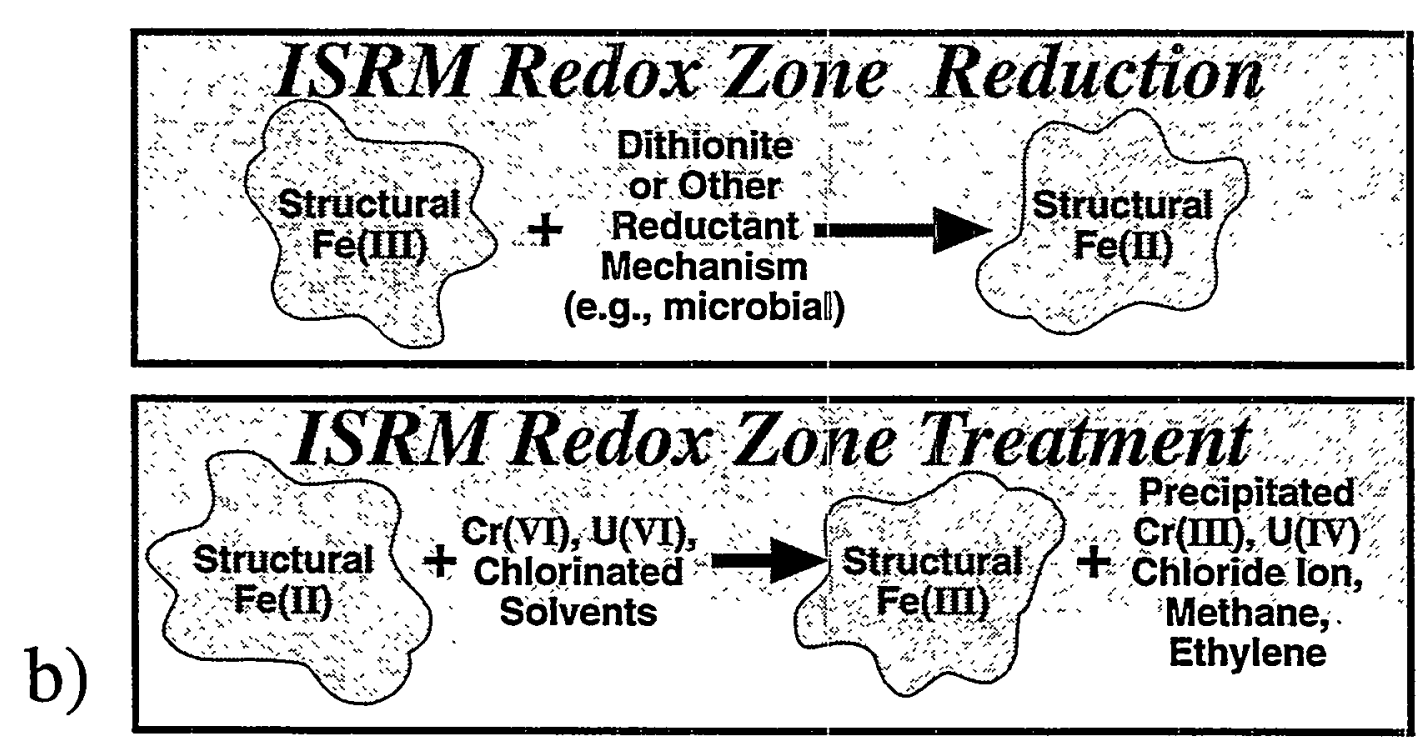

Figure 1.4. In Situ Redox Manipulation Concept 
unconfined aquifer sediments. Using standard wells to create the treatment zone allows treatment of contaminants too deep for conventional trench-and-fill technologies. Sodium dithionite is a strong reducing agent that has a number of desirable characteristics for this type of application, including instability in the natural environment ( days), with reaction and degradation products that ultimately oxidize to sulfate. Potassium carbonate/bicarbonate is added to the injection solution as a pH buffer to enhance the stability of dithionite during the reduction of available iron. Unreacted reagent and reaction products are pumped out of the aquifer through the same well used for injection, starting about two days after injection.

Chromate $\left(\mathrm{CrO}_{4}{ }^{2}\right)$, which is anionic in nature and soluble in groundwater, contains hexavalent chromium, $\mathrm{Cr}^{6+}$. The altered subsurface environment containing the reduced iron $\left(\mathrm{Fe}^{2+}\right)$ will act upon the $\mathrm{Cr}^{6+}$ species, reducing it to $\mathrm{Cr}^{3+}$, which will then precipitate from the groundwater as $\mathrm{Cr}(\mathrm{OH})_{3}$, which is immobile. Thus chromium is immobilized (see Figure 1.4b).

An ISRM permeable treatment zone is emplaced perpendicular to the groundwater flow to intercept the contaminant plume, as shown in Figure 1.5. This geometry is created by a series of overlapping injection/withdrawal wells. The design of the injection/ withdrawal wells for this Treatability Test is shown in Figure 1.6. The width of the permeable treatment zone (in the direction of groundwater flow) determines the longevity of the zone, based on the treatment capacity of the sediment (i.e., the amount of reducible iron in the sediment and the efficiency of the emplacement). The width of the permeable treatment zone multiplied by the pore volumes of treatment capacity of the reduced zone determines the upgradient distance of contaminated groundwater that can be treated. The treatment capacity is a function of the amount of reducible iron in the sediment, the efficiency of the reduction by the field emplacement (dithionite concentrations and time), and the oxidizing potential of the groundwater (e.g., dissolved oxygen and chromate concentrations). Groundwater velocities at the site determine the longevity of the treatment zone. Other dimensions of the permeable treatment zone (i.e., length and depth) are determined by the extent of contamination required to be treated.

An independent cost analysis was conducted to compare a hypothetical small-scale ISRM system with a pump-and-treat operation over 10 years of operation (Cummings 1997). This study concluded that the ISRM system resulted in an overall cost savings of $62 \%$ for this period. A longer-term remediation would result in further savings for the ISRM system over the pump and treat because, once installed, the ISRM system requires much less operation and maintenance, mostly just periodic monitoring and reporting.

\subsection{Test Summary}

Well installation for the 100-D Area ISRM Treatability Test started in the spring of 1997 . Well installation and site characterization activities continued through the summer of and were completed in November 1997. Characterization activities included sampling the sediment, testing the aquifer, establishing baseline aqueous geochemistry, and conducting a bromide tracer test. The first dithionite injection/withdrawal took place during September and October of 1997; ground water monitoring was conducted from the fall of 1997 to the spring of 1998. The remaining four dithionite injection/withdrawal tests were conducted from May to July 1998. 


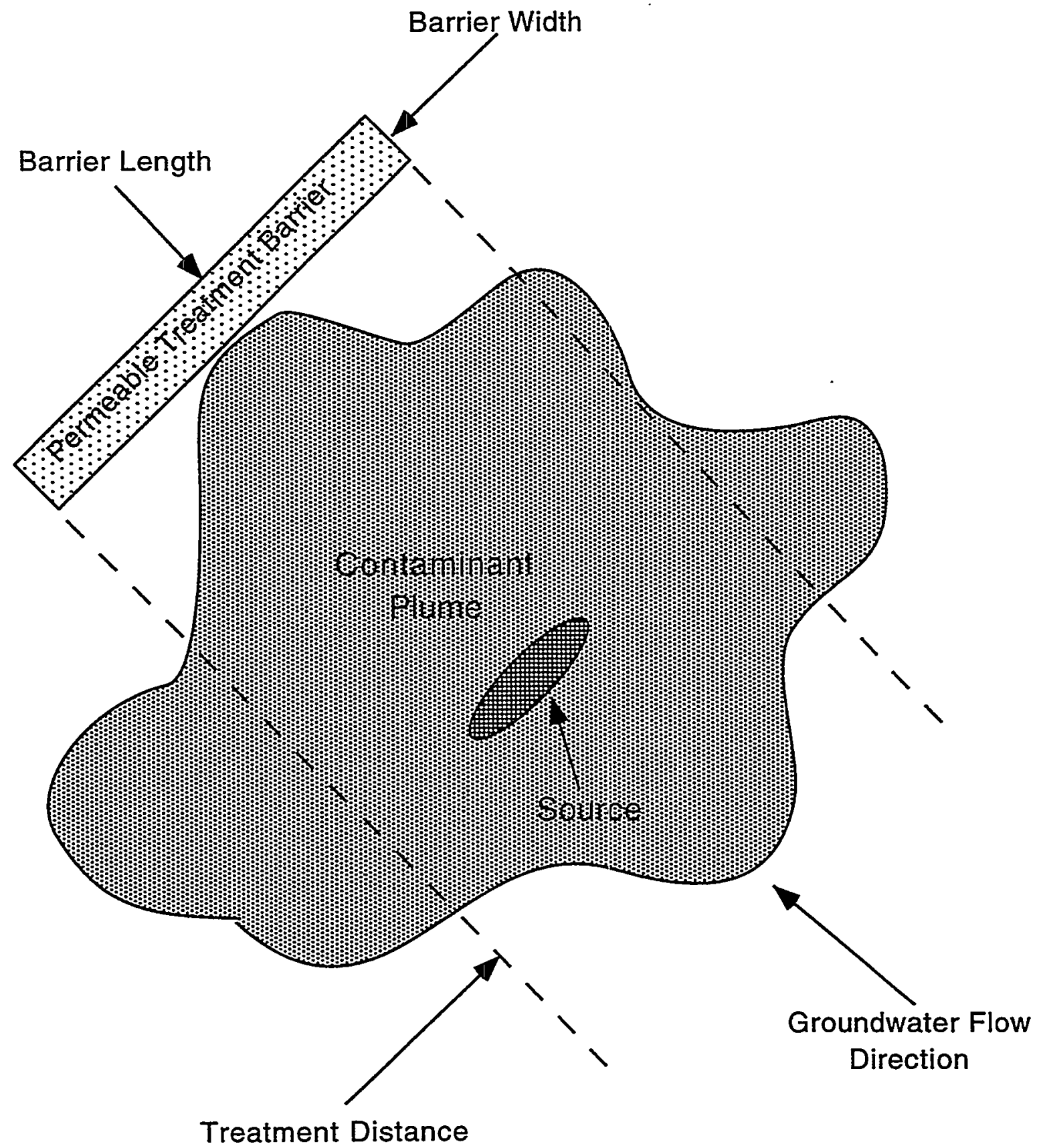

Figure 1.5. Conceptual Diagram of In Situ Redox Manipulation Permeable Treatment Barrier 


\section{0-D Area ISRM Site \\ $\bigcirc_{D 4-6}$}

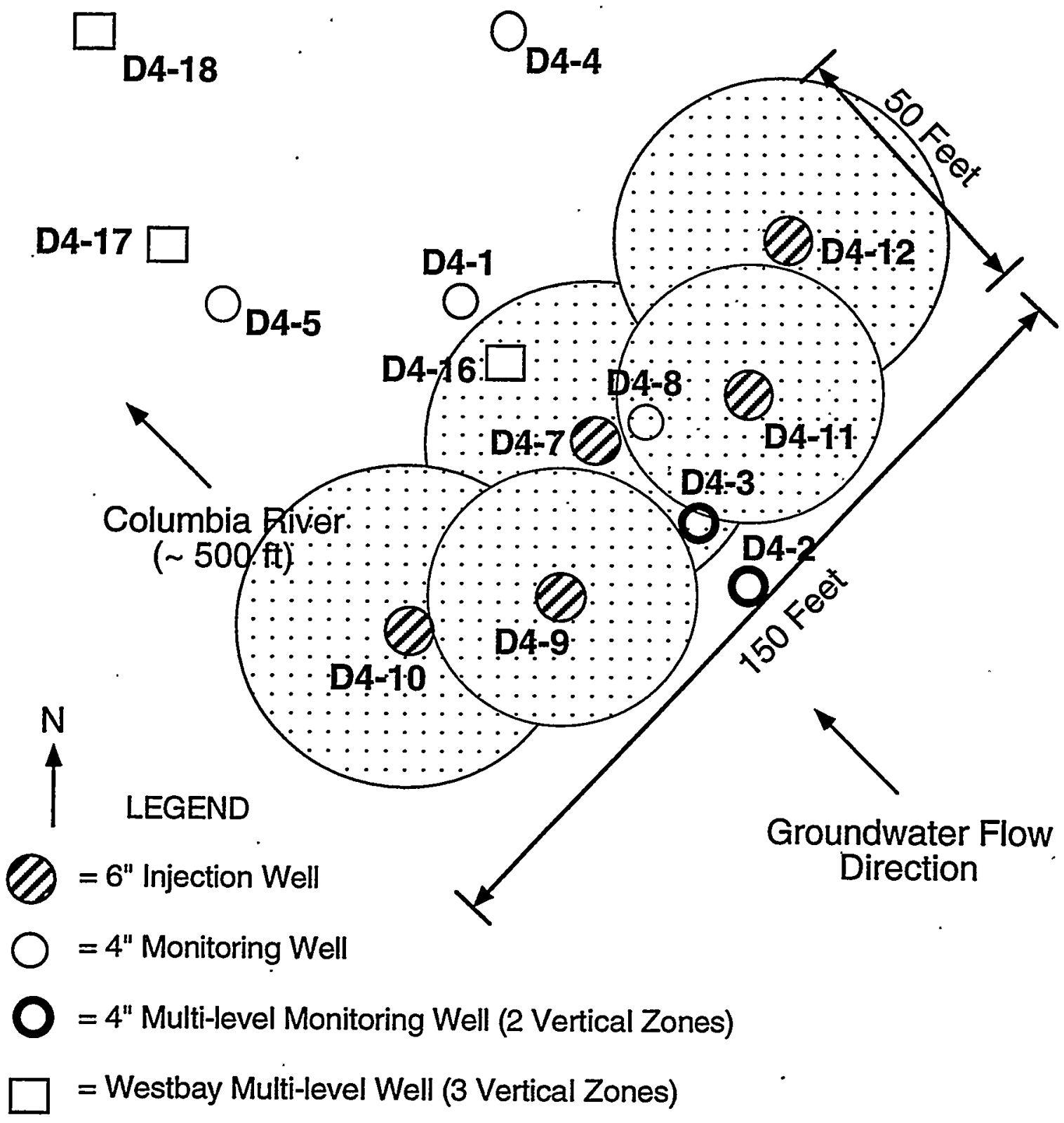

Figure 1.6. Emplacement Strategy and Well Diagram for the 100-D Area In Situ Redox Manipulation Treatability Test 
As shown in Figure 1.6, these dithionite injections and withdrawals created a reduced zone in the aquifer approximately $150 \mathrm{ft}$ long (perpendicular to groundwater flow), $50 \mathrm{ft}$ wide, and $\sim 15 \mathrm{ft}$ thick, extending over the thickness of the unconfined aquifer. Laboratory analysis of sediment collected from the aquifer during the initial drilling measured an average treatment capacity of the sediment of $171 \pm 46$ pore volumes of groundwater from the site. Using $1 \mathrm{ft} /$ day groundwater velocity (as measured at the site) and a $50 \mathrm{ft}$ width, this treatment capacity results in a predicted longevity of the 100-D Area ISRM permeable treatment zone of $23 \pm 6$ years.

Analysis of the most recent groundwater sampling event at the site (September 3, 1998) showed $\mathrm{Cr}^{6+}$ concentrations below detection limits $(0.007 \mathrm{mg} / \mathrm{L})$ within the treatment zone compared with average baseline concentrations of $0.91 \mathrm{mg} / \mathrm{L}$ within these wells. $\mathrm{Cr}^{6+}$ concentrations in the downgradient wells are significantly below baseline values (approximately 50\%), but sufficient time has not elapsed since the injection/withdrawal tests for the hydraulic gradient to return to normal and for the travel time to downgradient wells. Dissolved oxygen concentrations are also significantly lower within the treatment zone and downgradient wells than the baseline values. Sulfate, $\mathrm{Na}$, and $\mathrm{K}$ concentrations are elevated at the site from the dithionite residuals. Major trace metals involved in the redox process $(\mathrm{Fe}, \mathrm{Mn})$ are elevated above baseline values in the reduced zone due to dissolution of $\mathrm{Fe}$ and $\mathrm{Mn}$ oxides by the dithionite solution and the enhanced solubility of these naturally occurring oxides in the aquifer sediments under reducing conditions. Although these are elevated in the treatment zone, they are likely not mobilized downgradient from the zone due to their high retardation factors and re-precipitation once they contact oxidizing sediments outside the zone, as shown in column experiments for hundreds of pore volumes.

Groundwater monitoring at the site will continue on a monthly to bimonthly basis through FY 1999. Digging core holes for collecting sediment from the dithionite treated zone and installing an additional upgradient and downgradient wells are planned for FY 1999. The installation of additional wells to characterize the extent of the chromate plume and to expand the ISRM permeable treatment zone at 100-D Area has also been proposed for FY 1999. 


\subsection{Site Setup}

The specific location of the 100-D Area In Situ Redox Manipulation Treatability Test site is shown in Figure 2.1. This figure also shows the wells and Columbia River substrate pore water sampling tubes (northwest of the site along the river shoreline) used for emplacement and performance monitoring of the test. An expanded view of the wells at the site, based on survey data, is shown in Figure 2.2. Figure 2.3 shows a composite photograph of the ISRM site with the wells, field trailers, mixing and storage tanks, and analytical equipment. The setup, facilities, and equipment for the test are described in the sections that follow.

\subsection{Wells}

As shown in Figure 1.6, four types of wells were installed at the 100-D Area ISRM site as part of the Treatability Test: injection/withdrawal wells, monitoring wells, multi-level monitoring wells, and Westbay monitoring wells. All these types of wells were installed using the reverse air rotary method (ODEX). Completion summaries for these wells are listed in Appendix A. A description of these different types of wells used in the treatability study is listed below.

The five injection/withdrawal wells installed at the site (D4-7, D4-9, D4-10, D4-11, D4-12) were used for the ISRM permeable barrier emplacement and groundwater monitoring. The injection/ withdrawal wells consist of 6-in.-diameter schedule $40 \mathrm{PVC}$ with 20-slot continuous wire wrap screens. These wells are screened across the average saturated thickness of the aquifer ( $15 \mathrm{ft})$. They are spaced $28 \mathrm{ft}$ apart with a primary row of three injection/withdrawal wells (D4-10, D4-7, and D4-12) spaced $50 \mathrm{ft}$ apart and a row of two overlapping injection/withdrawal wells (D4-9 and D4-11) to fill the interstices and for monitoring during the primary emplacement. Reagent volumes were smaller for the overlapping wells than for the primary wells.

The four standard monitoring wells (D4-4, D4-5, D4-6, D4-8) installed at the site were used for baseline and performance monitoring of the permeable treatment zone. One well, D4-8, was also used to help determine dithionite concentrations at various distances during emplacement. Monitoring wells were constructed of 4-in.-diameter schedule 40 PVC with 20-slot continuous wire wrap screens. Screen lengths of $20 \mathrm{ft}$ were used for these wells to match the sampling interval of surrounding monitoring wells used for the Hanford Sitewide Groundwater Monitoring Program. Except for D4-8, these wells are located downgradient from the permeable treatment zone to determine the extent of the treatment zone's effectiveness and to assess effects of the technology on groundwater quality (e.g., chromate, dissolved oxygen, and trace metals).

In addition to the standard monitoring wells, two multilevel monitoring wells (D4-2 and D4-3) were installed on the upgradient side of the permeable treatment zone. Each of these wells has two 4.5-ft screen intervals at the top and bottom of the aquifer separated by a 5 - $\mathrm{ft}$ section of casing and an inflatable packer. The purpose of these wells was to identify vertical differences in chromate concentrations at the site, determine vertical hydraulic conductivity and anisotropy, and monitor tracer/dithionite concentrations during injection/withdrawal tests to determine arrival times between the upper and lower portions of the aquifer. 


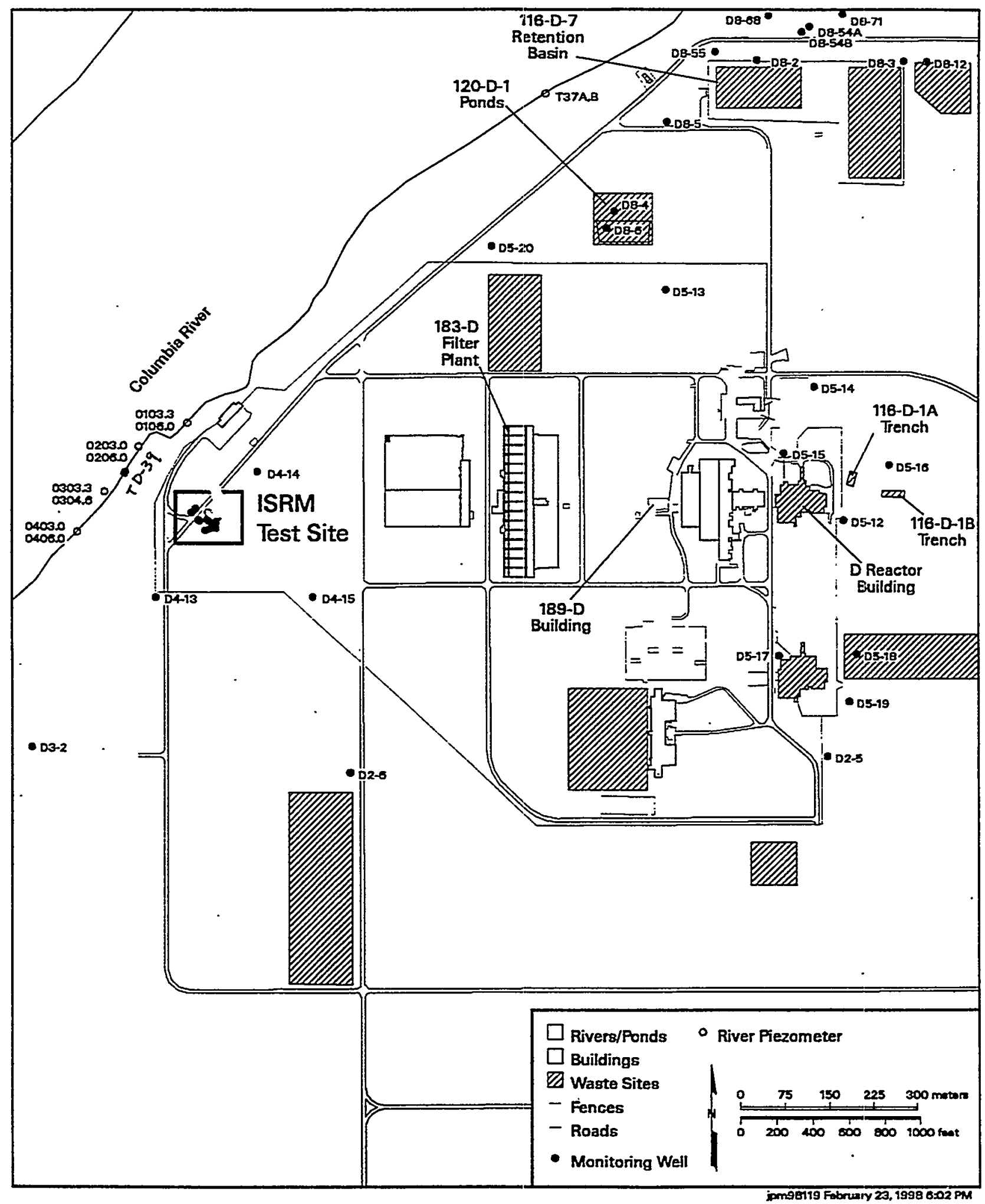

Figure 2.1. 100-D Area Wells and ISRM Site. The Columbia River Substrate Porewater Sampling Tubes are NW of the Site (0103.3 to 0403.0). 


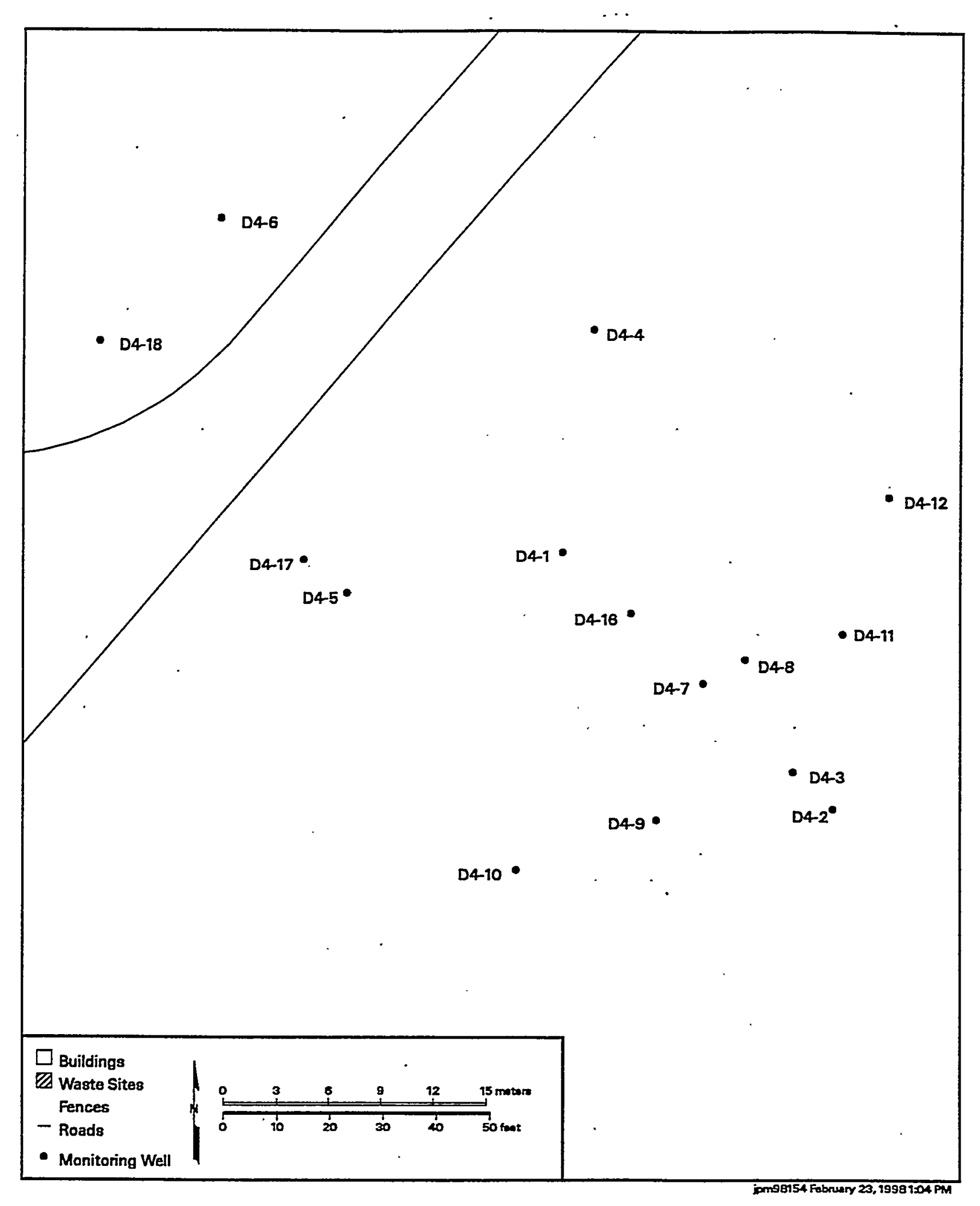

Figure 2.2. 100-D Area ISRM Wells from Survey Locations 


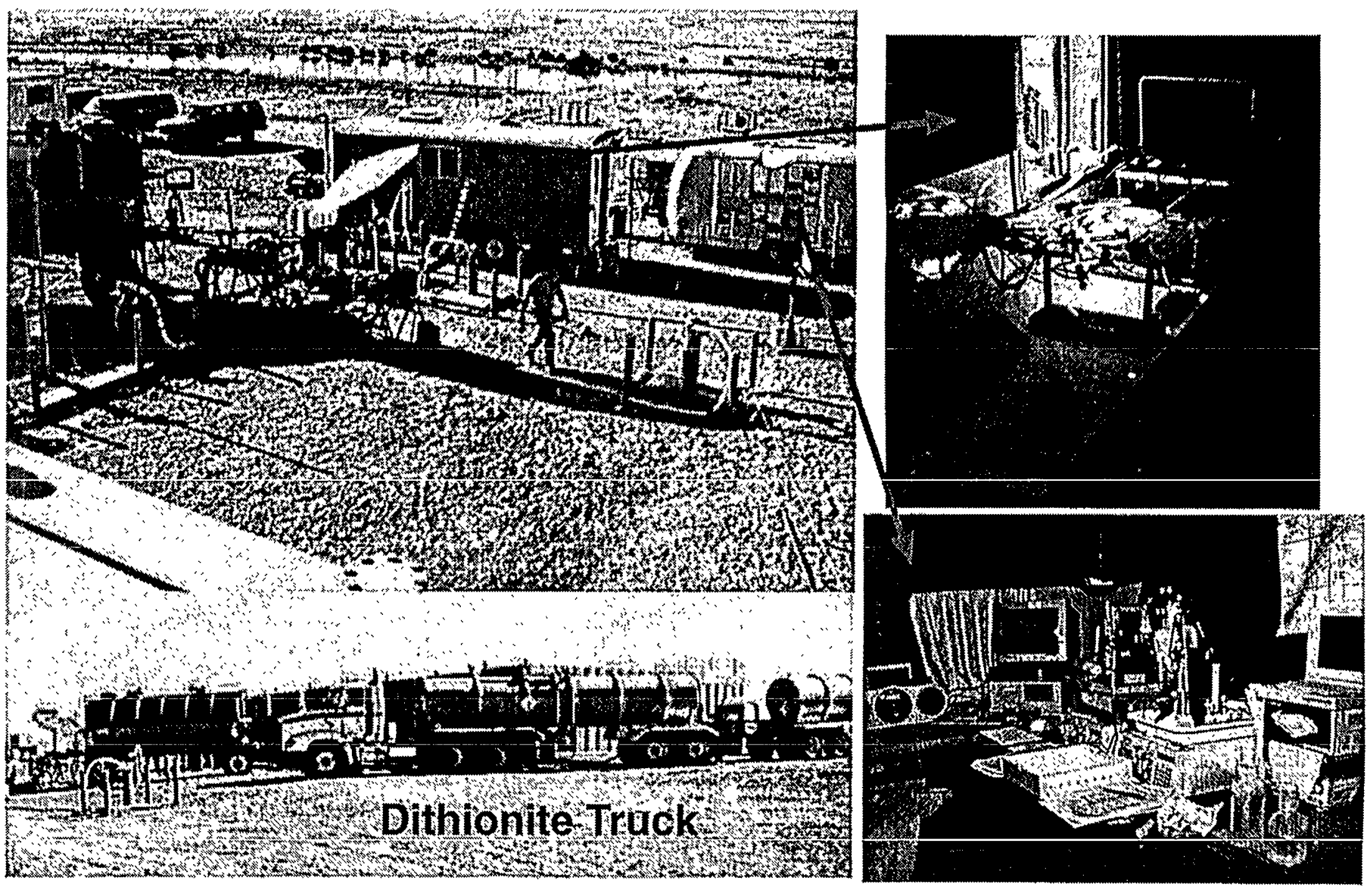

Figure 2.3. Photographs of Site Setup and Equipment at the 100-D Area In Situ Redox Treatability Test Site 
The fourth type of well installed at the site was the Westbay multilevel monitoring wells (D4-16, D4-17, and D4-18). The Westbay wells permitted three discrete vertical sampling intervals. One of these wells (D4-16) is located within the treatment zone and was used for monitoring dithionite concentrations during injection/withdrawal tests. The remaining two Westbay wells are located on the downgradient side of the treatment zone to help identify vertical differences in chromate concentration and dissolved oxygen.

\subsection{Columbia River Substrate Pore Water Sampling Tubes}

A series of sampling tubes was installed in the substrate of the Columbia River (see Figure 2.1) to monitor the groundwater entering the river and determine any impact from the test on the water quality. Four pairs of sampling tubes were installed about $300 \mathrm{ft}$ apart in the river. Each pair includes a shallow ( $\sim 3-\mathrm{ft}$ depth) and a deep ( $-6-\mathrm{ft}$ depth) monitoring interval. In addition to the sampling tubes installed for the ISRM test, an existing set of multilevel sampling tubes (TD39 - located between 0203.0 and 0303.3) is monitored as part of this test. Details on the installation of these sampling tubes are described in Peterson et al. (1998).

A portable peristaltic pump is used to collect water samples from these sampling tubes. Electrical conductivity, $\mathrm{pH}$, and dissolved oxygen are measured in the field using electrodes during purging of the tubes. Water samples are collected for chromate and anion analysis once the electrode values are stabilized and recorded (purge time varied from five to 15 minutes based on length of hose).

\subsection{Tanks}

Ten 20,000 gallon frac tanks were used to hold groundwater for dilution of concentrated tracer solutions for tracer tests and reagent for the treatment zone emplacement. The groundwater in these tanks was also used for a "fresh-water push" at the end of the injection stages for the tracer and dithionite injection/withdrawal tests (for details, see Section 3). These tanks were also used to store withdrawal water from the dithionite injection/withdrawal tests prior to disposal.

In the first dithionite injection/withdrawal test, all the withdrawn water was stored in the frac tanks. Following analysis, the withdrawn water was trucked to the 200-Area Effluent Treatment Facility (ETF) for disposal. On subsequent dithionite injection/ withdrawals, the first injection volume withdrawn $(-40,000 \mathrm{gal})$ was stored in frac tanks and disposed of in the 200-Area purge water modutanks. The remaining withdrawal volume from these tests (up to 160,000 gal) was purged to the ground through a 500-ft-long drip irrigation system (2-gph emitters spaced $1 \mathrm{ft}$ apart) to the west of the ISRM site upgradient of Well D4-13 (see Figure 2.1 for well location). The irrigation system was designed for a 15-gpm application rate.

A 4,000 gallon mixing tank was also used at the site for preparing the bromide tracer solution for the tracer test and for storing the concentrated dithionite solution prior to injection during the first two injection/withdrawal tests. On subsequent injection/ withdrawal tests, the dithionite injection pump was connected directly to the tanker truck, which stayed at the site for the duration of the injection ( 10 hours). 


\subsection{Injection and Withdrawal Pumps}

Two pumps were used for the bromide tracer test and the dithionite injection/withdrawal test. A 0.75-hp stainless steel Grundfos centrifugal pump was used to inject the concentrated solution, and a 3-hp Monarch centrifugal pump (standard irrigation pump) was used to pump groundwater stored in Frac tanks for dilution. Mixing and dilution occurred within the injection line. Iomega turbine flow meters were installed to measure flow from each pump. These flow meters were continually logged with a Campbell Scientific CR10 datalogger that also permitted real-time monitoring for adjusting flow rates during the injections to obtain the desired concentrations. This mixing strategy also permitted time-varying concentrations during the dithionite injection, which was used in later tests.

For the withdrawal, a submersible pump was used in the injection/withdrawal well. The manifold for the outflow from the withdrawal pump also was connected to 50-micron filters prior . to discharging the water to the frac tanks or the irrigation system for purging to the ground.

\subsection{Water Levels}

Water levels were measured using a high accuracy, NIST traceable, non-stretch, metal taped water-level meter marked in 0.01 -ft gradations. Pressure transducers (10 and $20 \mathrm{psi}, 0.1 \%$ of full-scale accuracy) were installed in most of the wells to monitor pressure response during hydraulic and dithionite/tracer injection tests and for measuring the response of the water table to changes in the Columbia River stage. Transducer readings were validated periodically with water-level measurements during all phases of testing to check for transducer drift.

Water-level measurements were collected over as short a time period as possible. Initial measurements were rechecked throughout the measurement period to quantify any water-level changes due to external stress (e.g., river stage fluctuation, barometric pressure change).

\subsection{Groundwater Sampling and Analysis}

Dedicated Grundfos Rediflow sampling pumps were installed in most of the wells at the site (the exceptions were D4-6, which is located across a road from the site, and the Westbay wells). The hoses from these sampling pumps were connected clirectly to a sampling manifold located inside the mobile laboratory. Individual pumps can be selected and sampled from within the field trailer.

The main method for groundwater sample collection and measurement of the field parameters ( $\mathrm{pH}$, temperature, electrical conductivity, and dissolved oxygen) is through the sampling manifold in the field trailer. A series of flow-through probes is connected to the discharge line of the sampling manifold. Purge times were determined by calculating wellbore volumes and by the stabilization of the readings from the flow-through probes. Flowrates were approximately $2 \mathrm{gpm}$ during sampling with sample times varying from three to five minutes. In addition to field measurements, archive samples are collected for analysis of hexavalent chromium anions, major anions, trace metals, and dithionite. Groundwater samples were collected for trace metal analysis, filtered ( 0.45 micron), and $12 \mathrm{~mL}$ preserved with $2 \mathrm{~mL}$ of ultrapure nitric acid. 
Water samples were also collected for duplicate field parameter analysis on a separate verification station. This verification station was the only method used for the samples collected from the Westbay wells due to the limited sample volume $(500 \mathrm{~mL})$. Initially, the probes used for the verification station were the same as those in the flow-through manifold. This was changed in May 1998, when the probes in the verification station were changed to micro-flow-through probes using a syringe pump. This permitted the sample to be collected and run directly in a $10 \mathrm{~mL}$ disposable syringe, thus limiting the contact with the atmospheric oxygen for the sample.

Hexavalent chromium concentrations were measured in the mobile field.laboratory at the site using a Hach DR-2000 spectrophotometer and Accuvac Chromaver 3 ampules. The detection limit of this method is $0.007 \mathrm{mg} / \mathrm{L}$, and the method is EPA approved. Samples are filtered using a 0.45 -micron filter prior to hexavalent chromium analysis.

Dithionite measurements are also made in the field trailer during the dithionite injection/ withdrawal tests. Due to the instability of dithionite and its reactivity with oxygen, these analyses must be conducted immediately following sample collection. An automated system was developed using syringe pumps for sample dilution and a high-performance liquid chromatograph (HPLC). The dilution water was sparged with nitrogen gas to be completely free of dissolved oxygen because of the high dilution factors required for this method (500 to 700 times). 


\subsection{Site Characterization Results}

\subsection{Hydrogeologic Setting}

The general hydrogeologic setting of the 100-HR-3 Operable Unit (encompassing the 100-D and 100-H Areas) is described in Lindsey and Jaeger (1993). Characterization activities of the uppermost unconfined aquifer performed while drilling the wells at the ISRM site conform to the generalized setting for the 100-D Areas and were similar to the cross-section shown in Figure 1.4. Specifically, the unconfined aquifer at the ISRM test site is within a gravel unit of the Ringold Formation. The bottom of the unconfined aquifer is composed of a Ringold mud unit (overbank deposits and paleosols). Deviations in the elevation of the confining unit bounding the bottom of the unconfined aquifer were less than two feet during the drilling of the 15 wells at the site. The unconfined aquifer thickness at the test site is $15 \mathrm{ft}$ during normal stage of the Columbia River. The groundwater flow direction is roughly toward the Columbia River (NW or WNW) during normal river stage.

The ISRM site is approximately $500 \mathrm{ft}$ from the Columbia River, and the water table elevation at the site is strongly influenced by the river. Numerical modeling of these effects are shown for the $100 \mathrm{~N}$-Area (with a similar hydrogeology and located upriver from the 100-D Area) in Connelly et al. (1997a). For example, hourly water-level elevation measurements (via automated datalogging of pressure transducers installed in the wells) respond to daily, weekly, and seasonal fluctuations in the river stage (although the amplitude is dampened). In addition, the aquifer response form record flooding during the winter of 1997 increased the aquifer thickness from $15 \mathrm{ft}$ to about $20 \mathrm{ft}$. Early water table measurements made at the site show the groundwater flow reversed direction by 180 degrees, flowing away from the river. Water table elevations decreased throughout the summer of 1997, dropping by $5 \mathrm{ft}$ by the fall. The uppermost zone of the Westbay wells (with three vertical sampling intervals, as described below) installed at the site have dried up occasionally during daily low river stage.

\subsubsection{Geology}

The geology of the site, determined from wellsite geologist logs, was relatively consistent across the site and similar to that shown for well D4-1 in Figure 1.3. The depth to the water table was approximately $80 \mathrm{ft}$ during the initial stage of well drilling. Above the water table were sand, sandy gravel, and gravelly sand units. The Hanford/Ringold formation contact ranged from 50 to $57 \mathrm{ft}$ bgs (below ground surface). The unconfined aquifer was in the Ringold Formation and is predominantly sandy gravel and silty sandy gravel. A sandy layer was also detected in most of the wells slightly above the water table. The bottom of the unconfined aquifer was bounded by a Ringold silt/clay layer at 96 to $98 \mathrm{ft}$ bgs. The thickness of this silt/clay unit was not determined because drilling was stopped at about a $5 \mathrm{ft}$ penetration into this unit.

\subsubsection{Physical Properties of Sediment Samples}

Physical property measurements (porosity, bulk density, and particle size distribution by sieve analysis) were made on 15 split tube samples collected during drilling. The results are shown in 
Appendix C. Particle size ranged from 65 to $85 \%$ gravel, 14 to $31 \%$ sand, and less than $6 \%$ fines (silt/clay). Porosity ranged from 5 to $23 \%$ with a mean of $14 \%$. Bulk density ranged from 2.1 to 2.4 with a mean of $2.3 \mathrm{~g} / \mathrm{cm}^{3}$.

Analysis of the sediment samples also showed a layer of cemented mud ripup clasts in three of the wells (D4-3, D4-4, and D4-5) at a depth interval of 84 to $85 \mathrm{ft}$. The ripup clast zone was not observed by well-site geologists during drilling.

\subsection{Hydraulic Testing}

Pre- and post- dithionite injection hydraulic tests were conducted to obtain the baseline hydraulic properties required to design the ISRM treatability test and to determine whether the technology caused any significant changes in the formations' hydraulic properties that could alter the groundwater flow direction (e.g., a decrease in hydraulic conductivity associated with formation plugging within the treatment zone). Two constant-rate discharge tests were conducted at the ISRM Treatability Test Site, one prior to the dithionite injections to characterize baseline conditions and one following the dithionite injection in D4-7 to assess impacts of the technology on aquifer hydraulic properties within the treatment zone; the assessment incorporated the analysis of test response data from the injection well and seven surrounding observation wells. A discussion of test results and analysis plots is contained in Appendix B.

Analysis of stress and observation well response data from the pre-injection constant-rate discharge test (baseline conditions) indicates, on average, a hydraulic conductivity of $54 \mathrm{ft} / \mathrm{d}$, vertical anisotropy of 0.01 , and storativity of 0.004 . Composite analysis suggests that horizontal anisotropic conditions likely exist in the aquifer, and analysis of multilevel observation well response data indicates the presence of a vertically heterogeneous or multilayered system. Both of these findings are consistent with tracer arrival data from the tracer injection test that indicates preferential flow paths between some of the monitoring wells and significantly larger groundwater velocities in the upper part of the aquifer than in the lower part.

Comparison of the pre- and post-injection test responses indicates there are discernable effects associated with the emplacement of the ISRM treatment zone, including formation of a significant skin, or zone, of reduced permeability immediately surrounding the injection well (D4-7) and a slight increase in hydraulic conductivity for aquifer materials within the treatment zone. The observed post-injection response is consistent with a conceptual model in which permeability of the aquifer is enhanced by chemical and dissolution reactions during injection of the reagent, while a zone of reduced permeability is generated around the injection well by deposition during the withdrawal phase. The extent and severity of the zone of permeability reduction surrounding the injection well cannot be determined uniquely by comparing pre- and

post-injection test responses, but it is most likely limited to the region of the sand-pack/formation interface.

\subsection{Groundwater Flow Direction}

Since field activities at the ISRM Treatability Test Site were initiated in the fall of 1997, water levels in site monitoring wells have been routinely monitored to determine the hydraulic gradient, groundwater flow direction, and the variability in these parameters over the time scale 
of the treatability test. Water-level measurements, along with horizontal and vertical survey data for each well site location, were used to estimate the local gradient and flow direction.

The estimated groundwater flow velocities shown in Figure 3.1 are based on measured hydraulic gradients, an average hydraulic conductivity of $54 \mathrm{ft} /$ day obtained from hydraulic tests conducted in site monitoring wells, and an average sediment porosity of 0.14 obtained from the analysis of sediment core collected during installation of monitoring wells. As indicated, groundwater typically flows to the west-northwest at approximately $1 \mathrm{ft} /$ day. The deviation from this typical flow direction during the first two monitoring events (8/21/97 and 9/8/97) is most likely associated with recovery from historically high Columbia River flows during the spring and summer of 1997. Water levels in the wells dropped approximately $5 \mathrm{ft}$ from the time of well installation (spring/summer of 1997) to the fall of 1997, resulting in a change of aquifer thickness from 20 to $15 \mathrm{ft}$.

\subsection{Chinook Salmon Survey}

Previous salmon surveys based on air-photo analysis indicated there were no fall Chinook salmon redds in the river in a downgradient direction (NW or WNW) of the ISRM site (Hope and Peterson 1996; Luttrell et al. 1995). Hope and Peterson (1996) concluded, based on river substrate characterization conducted along the 100-D and 100-H sections of the Columbia River conducted by divers, that that the stretch of river downgradient from the site (upstream of $D$ Island in the vicinity of the "100-D/DR hot spot") was unsuitable for salmon spawning or egg incubation because of the substrate embeddedness (Hope and Peterson 1996).

A more detailed salmon survey was conducted as part of the ISRM Treatability Test of the section of the river downgradient from the ISRM site (Mueller and Geist 1998). No fall Chinook salmon redds were discovered in the area during either the aerial or underwater video surveys. The study also concluded that "less than 1\% of the study area adjacent to the ISRM experiment would be considered suitable for fall Chinook salmon spawning" (Mueller and Geist 1998, p. 11) based on detailed measurements along 11 transects of dominant and subdominant substrate, depth, and velocity.

\subsection{Baseline Aqueous Geochemistry}

Groundwater samples were collected and analyzed from all the wells at the ISRM site prior to the D4-7 dithionite injection/withdrawal test (September 29, 1997) to establish the baseline aqueous geochemistry of the site. Field parameters $(\mathrm{pH}, \mathrm{DO}$, electrical conductivity, hexavalent chromium) were measured on all samples collected, and a complete set of analyses was run on two sampling rounds (major anions and trace metals). The results from the latest complete baseline sampling round are listed in Tables 3.1 and 3.2. The values for Westbay wells D4-17 and D4-18 were not included because these wells were not completed in time for the baseline sampling. Table 3.3 lists the range and average field parameters measured at the site from the 


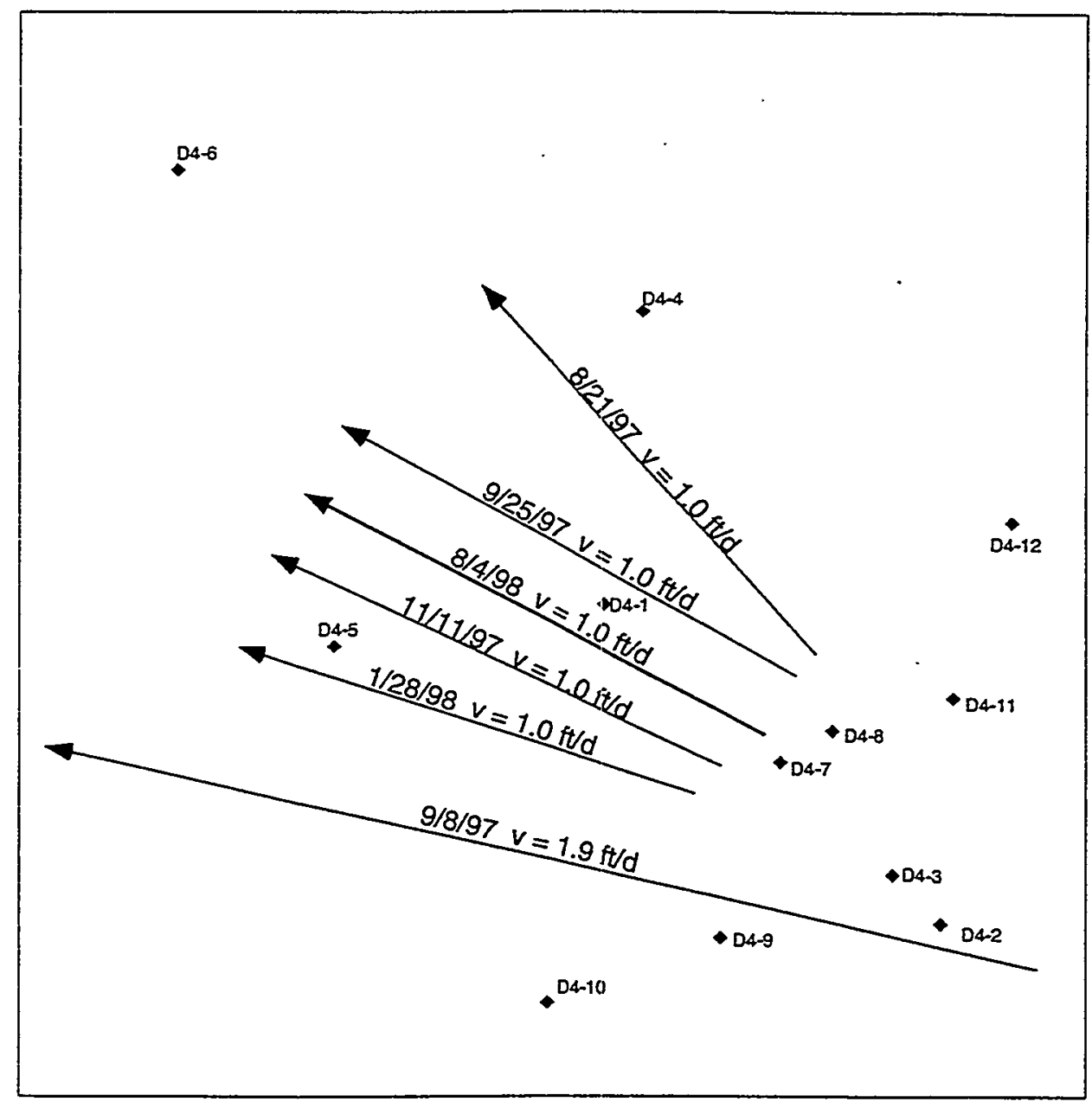

Figure 3.1. Groundwater Flow Directions and Magnitudes Measured at the 100-D Area ISRM Site

latest baseline analysis. Plan view and cross-section diagrams of this baseline hexavalent chromium data are shown in Figures 3.2 and 3.3. Figure 3.4 shows a plan view diagram for baseline sampling of measured dissolved oxygen concentrations.

\subsection{Columbia River Substrate Pore Water Samplers}

The Columbia River substrate pore water sampling tubes were not installed until November and December 1997 (see Figure 2.1), which was after the D4-7 dithionite injection/withdrawal test. Therefore, none of the monitoring results for these pore water samplers can be considered as baseline values. These data are discussed in Section 6, and a complete listing of monitoring data is contained in Appendix C.

\subsection{Bromide Tracer Test}

A bromide tracer test was conducted on August 27, 1997, at the 100-D Area site. The objectives of this tracer test were as follows: 
1) Determine volumes and rates required for the dithionite injection/withdrawal tests

2) Establish breakthrough curves and arrival times for wells at different radial distances and orientations to assess the effect of horizontal and vertical heterogeneities at the site on groundwater flow

3) Test dual-injection pump setup and operation for metering/diluting concentrated solutions

4) Test sampling equipment and establish sampling interval requirements for dithionite tests

The test injected 40,000 gallons of $100 \mathrm{mg} / \mathrm{L} \mathrm{Br}$ (from $\mathrm{KBr}$ salts) into well $\mathrm{D} 4-7$ at 60 gallons permitted. Twenty-thousand gallons of groundwater were injected following the tracer solution at the same injection rate to increase the radius of influence of the tracer. The groundwater solution also provided additional information on arrival times.

Approximately 30,000 gallons of groundwater were withdrawn from the aquifer one month after the test to provide dilution water for the D4-7 dithionite injection/withdrawal test.

The results of this test showed that volumes lower than the preliminary estimates could be used for the dithionite injection/withdrawal tests. The total volume of 60,000 gallons used for the tracer test was reduced to 38,000 gallons for the first dithionite injection/ withdrawal test in well D4-7 (as discussed in the Section 4).

The results of the tracer test showed significant differences in arrival times between the upper and lower portions of the aquifer (see summary in Table 3.4). These results are listed in Appendix D. Arrival times in the upper portion of the aquifer, as measured in wells D4-2 Upper, D4-2 Upper and D4-16 zone 1, were significantly faster than in the lower screens of these wells. These differences are due to greater permeability and/or lower porosity of the upper portion of the aquifer. The wells that responded rapidly to the initial arrival of bromide solution also had similar drops in concentration when the injection solution was switched from the tracer solution to groundwater.

The breakthrough curves for the adjacent injection/withdrawal wells to D4-7 (D4-9 and D4-11) were slightly different. These wells are the same radial distance from D4-7 and are screened similarly. 
Table 3.1. Field Parameters and Major Anions from 9/29/97 Monitoring of ISRM Site. Sampling was conducted before the D4-7 Dithionite Injection.

\begin{tabular}{|c|c|c|c|c|c|c|c|c|c|c|c|c|}
\hline Well-ID & $\begin{array}{l}\text { FIELD } \\
\text { Cond } \\
\mu S / \mathrm{cm}\end{array}$ & $\begin{array}{l}\text { Sampled a } \\
\text { Cond } \\
\text { Temp. }\end{array}$ & $\begin{array}{l}\text { and Analys } \\
\text { Do } \\
\mathrm{mg} / \mathrm{L}\end{array}$ & $\begin{array}{l}\text { ed 9/29/97 } \\
\text { DO } \\
\text { Temp. }\end{array}$ & $\mathrm{pH}$ & $\begin{array}{c}(9 / 24 / 97) \\
\text { Cr6t } \\
\mathrm{mg} / \mathrm{l}\end{array}$ & $\begin{array}{l}\text { IC } \\
\mathrm{mg} / \mathrm{L}\end{array}$ & $\begin{array}{cl}\mathrm{Cl} \\
\therefore \mathrm{g} / \mathrm{L} \\
\end{array}$ & $\begin{array}{l}\mathrm{NO3} \\
\mathrm{mg} / \mathrm{L}\end{array}$ & $\begin{array}{c}\mathrm{PO4} \\
\mathrm{mg} / \mathrm{L}\end{array}$ & $\begin{array}{c}\mathrm{SO4} \\
\mathrm{mg} / \mathrm{L} \\
\end{array}$ & $\begin{array}{c}\text { Br- } \\
\mathrm{mg} / \mathrm{L}\end{array}$ \\
\hline D4-2 up & 455 & \begin{tabular}{|l|}
19.1 \\
\end{tabular} & 10.41 & \begin{tabular}{|r|}
19.0 \\
\end{tabular} & 7.71 & \begin{tabular}{|l|}
1.11 \\
\end{tabular} & \begin{tabular}{|r|}
0.5 \\
\end{tabular} & 23.8 & \begin{tabular}{|r|}
72.0 \\
\end{tabular} & \begin{tabular}{|r|}
6.1 \\
\end{tabular} & \begin{tabular}{|l|}
112.1 \\
\end{tabular} & $\mathrm{u}$ \\
\hline D4-2 low & 534 & 17.7 & 10.77 & 17.7 & 7.82 & 1.15 & 0.6 & 22.0 & 45.4 & 1.9 & 84.9 & $\mathrm{u}$ \\
\hline D4-3 up & 646 & 17.5 & 10.84 & 17.4 & 7.82 & 1.08 & & & & & & \\
\hline D4-3 low & 526 & 17.5 & 11.54 & 17.2 & 8.22 & 1.04 & $\mathrm{u}$ & 18.1 & 62.8 & u) & 124.9 & $\mathrm{u}$ \\
\hline D4-7 & 637 & 18.0 & 11.01 & 18.1 & 7.64 & 1.14 & $\underline{u}$ & 21.9 & 80.4 & $u$ & 141.5 & $\mathrm{u}$ \\
\hline D4-8 & 633 & 17.9 & 11.09 & 18.1 & 7.68 & 1.09 & $u$ & 21.1 & 79.2 & 0.8 & 139.7 & $\underline{u}$ \\
\hline D4-9 & 637 & 17.8 & 10.85 & 17.8 & 7.71 & 1.12 & $\mathrm{u}$ & 20.1 & 81.6 & $u$ & 139.4 & $\underline{u}$ \\
\hline $\mathrm{D} 4-11$ & 641 & 17.6 & 9.51 & 17.6 & 7.60 & 1.08 & $\mathrm{u}$ & 19.3 & 78.1 & $u$ & 141.4 & $\mathrm{u}$ \\
\hline D4-16(1) & 704 & 19.1 & 5.18 & 19.1 & 7.44 & 0.59 & 0.7 & 24.8 & 55.1 & 2.1 & 105.3 & 5.4 \\
\hline D4-16 (2) & 641 & 19.0 & 5.59 & 19.0 & 7.53 & 1.01 & 0.24 & 23.6 & 65.2 & 1.5 & 105.9 & 12.4 \\
\hline D4-16 (3) & 636 & 18.9 & 2.22 & 18.9 & 7.60 & 0.89 & 0.23 & 24.5 & 40 & 0.7 & 101.4 & 11.7 \\
\hline D4-i & 442 & 18.9 & 9.60 & 18.3 & 7.69 & 1.01 & 0.02 & 20.9 & 58.5 & 2.5 & 96.7 & $u$ \\
\hline D4-12 & 592 & 17.8 & 11.01 & 17.8 & 7.69 & 1.12 & 0.7 & 18.3 & 70.2 & u & 133.4 & $u$ \\
\hline D4-10 & 665 & 18.2 & 10.32 & 18.2 & 7.65 & 0.96 & $u$ & 20.6 & 83.0 & u. & 132.6 & $\mathrm{u}$ \\
\hline D4-4 & 622 & 18.3 & 10.03 & 18.4 & 7.59 & 0.74 & $\mathrm{u}$ & 17.4 & 73.7 & $u$ & 144.1 & $u$ \\
\hline D4-5 & 637 & 18.2 & 9.51 & 18.2 & 7.71 & $0.82^{\star}$ & 0.85 & 24.8 & 65.8 & 0.7 & 96.8 & 8.4 \\
\hline D4-6 & 594 & 18.2 & 10.71 & 18.0 & 7.68 & 0.92 & $\mathrm{u}$ & 17.2 & 70.1 & $u$ & 124.2 &. $\mathrm{u}$ \\
\hline \multicolumn{13}{|l|}{ D4-17(1) } \\
\hline \multicolumn{13}{|l|}{ D4-17(2) } \\
\hline \multicolumn{13}{|l|}{ D4-17(3) } \\
\hline \multicolumn{13}{|l|}{ D4-18(1) } \\
\hline \multicolumn{13}{|l|}{ D4-18(2) } \\
\hline D4-18 (3) & & & & & & & & & & & & \\
\hline
\end{tabular}

Notes: Cr6+ Data from 9/24/97 except for D4-5 which was from 9/17/97 


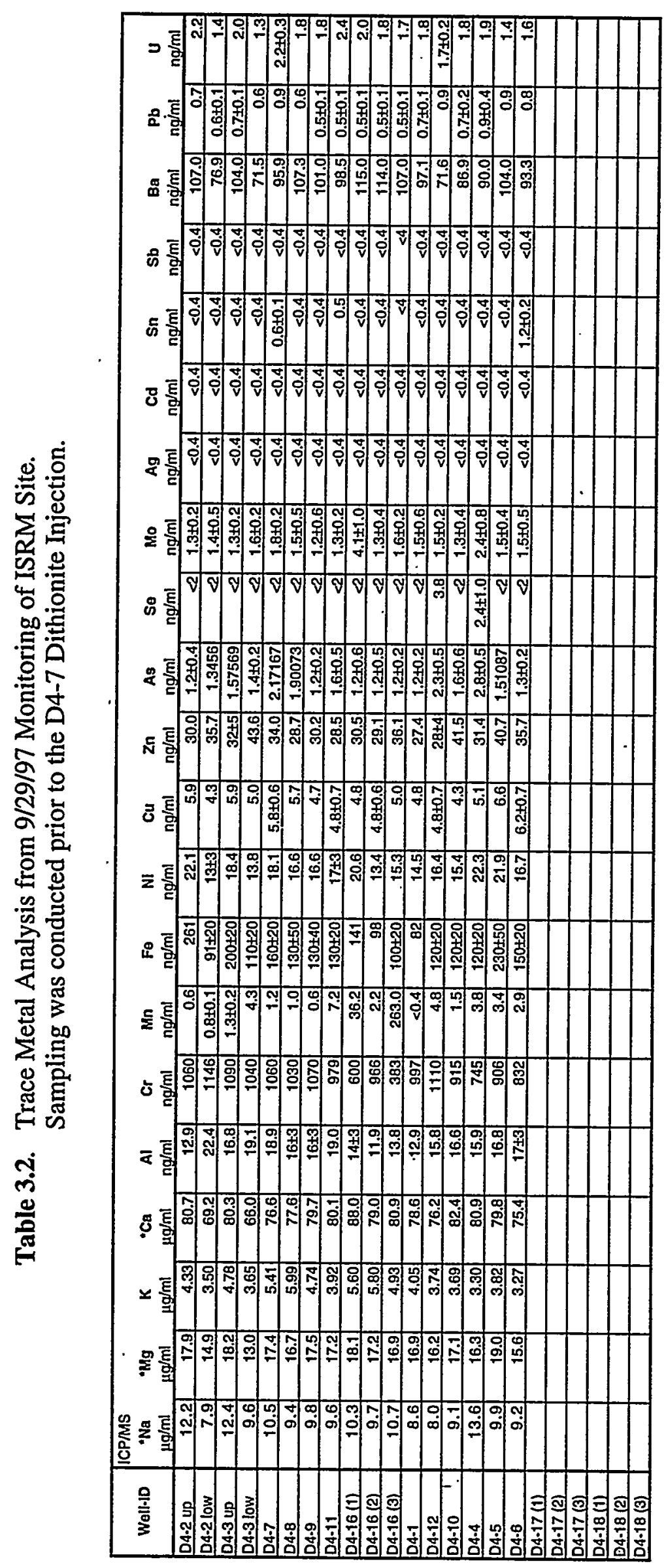


Table 3.3. Average Baseline Measurements at the 100-D Area ISRM Site (9-29-97)

\begin{tabular}{|l|c|c|c|}
\hline \multicolumn{1}{|c|}{ Parameter } & Units & Range & Average \\
\hline $\mathrm{pH}$ & & $7.44-8.22$ & 7.69 \\
\hline Electrical Conductivity & $\mu \mathrm{S} / \mathrm{cm}$ & $442-704$ & 602 \\
\hline Dissolved Oxygen & $\mathrm{mg} / \mathrm{L}$ & $2.22-11.54$ & 9.42 \\
\hline Sulfate & $\mathrm{mg} / \mathrm{L}$ & $84.9-144.1$ & 120 \\
\hline Hexavalent Chromium & $\mathrm{mg} / \mathrm{L}$ & $0.588-1.15$ & 1.00 \\
\hline
\end{tabular}

Table 3.4. Bromide Tracer Test: $\mathrm{Br}^{-}$Arrival Time Summary

\begin{tabular}{|c|c|c|c|c|c|}
\hline \multirow[b]{2}{*}{ Well } & \multirow[b]{2}{*}{$\begin{array}{l}\text { Screen } \\
\text { (ft bgs) }\end{array}$} & \multirow[b]{2}{*}{$\begin{array}{c}\text { Radial } \\
\text { Distance } \\
\text { (ft) }\end{array}$} & \multicolumn{2}{|c|}{ Arrival Time } & \multirow[b]{2}{*}{$\begin{array}{c}\text { Maximum } \\
\text { Conc. } \\
(\%)\end{array}$} \\
\hline & & & $\begin{array}{l}\mathbf{5 0 \%} \\
(\mathrm{min})\end{array}$ & $\begin{array}{r}100 \% \\
(\mathrm{~min})\end{array}$ & \\
\hline D4-7 & $81-96$ & 0 & 0 & 0 & 100 \\
\hline D4-8 & $75.6-95.6$ & 9.1 & 92 & 216 & 100 \\
\hline D4-16 (1) & $80-82.5$ & 20 & 160 & 414 & 100 \\
\hline $\mathrm{D} 4-16(2)$ & $86.5-89$ & 20 & 475 & - & 91 \\
\hline D4-16(3) & $93-95.5$ & 20 & 435 & - & 91 \\
\hline D4-3 (u) & $83.5-88.5$ & 24 & 47 & 300 & 100 \\
\hline D4-3 (1) & $93.5-98.5$ & 24 & 916 & - & 50 \\
\hline$\overline{\mathrm{D} 4-2(\mathrm{u})}$ & $83.6-88.6$ & 34.3 & 62 & 452 & 100 \\
\hline D4-2(1) & $93.6-99$ & 34.3 & - & - & 27 \\
\hline D4-9 & $82-97$ & 28.5 & 86 & 424 & 100 \\
\hline D4-11 & $91.2-96.2$ & 28.5 & 164 & 592 & 100 \\
\hline D4-1 & $74.6-94.7$ & 36.3 & - & - & 45 \\
\hline
\end{tabular}




\section{0-D Area ISRM Site $\mathrm{Cr}^{6+}(\mathrm{mg} / \mathrm{L})$ \\ 0.92 9-24-97 \\ 0.74 \\ 0}

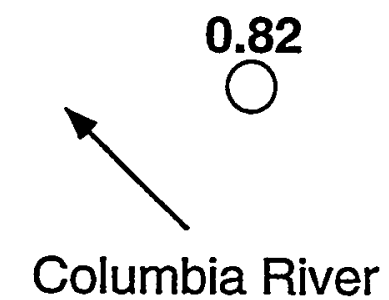

$(\sim 500 \mathrm{ft})$

$\mathrm{N}$

LEGEND

$\bigotimes=6^{\prime \prime}$. Injection Well

$\mathrm{O}=4^{\prime \prime}$ Monitoring Well

$\mathrm{O}=4^{\mathrm{u}}$ Multi-level Monitoring Well

$\square=$ Westbay Multi-level Well

1.01

0.96
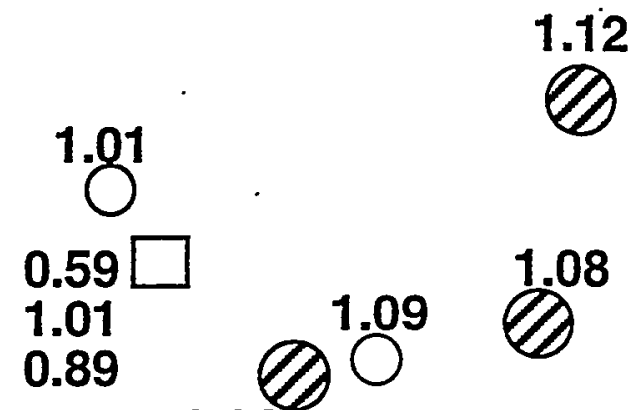

1.12

1.14

1.08

$0^{1.04}$

$1.11 \mathrm{O}$

1.15

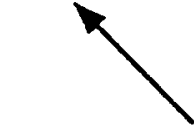

Groundwater Flow

Direction

Figure 3.2. Baseline Hexavalent Chromium Concentrations at the 100-D Areas ISRM Site 


\section{0-D Area In Situ Redox Manipulation}

Cr6+ (mg/L) 9/24/97

SW - NE TRANSECT (Cross Gradient)

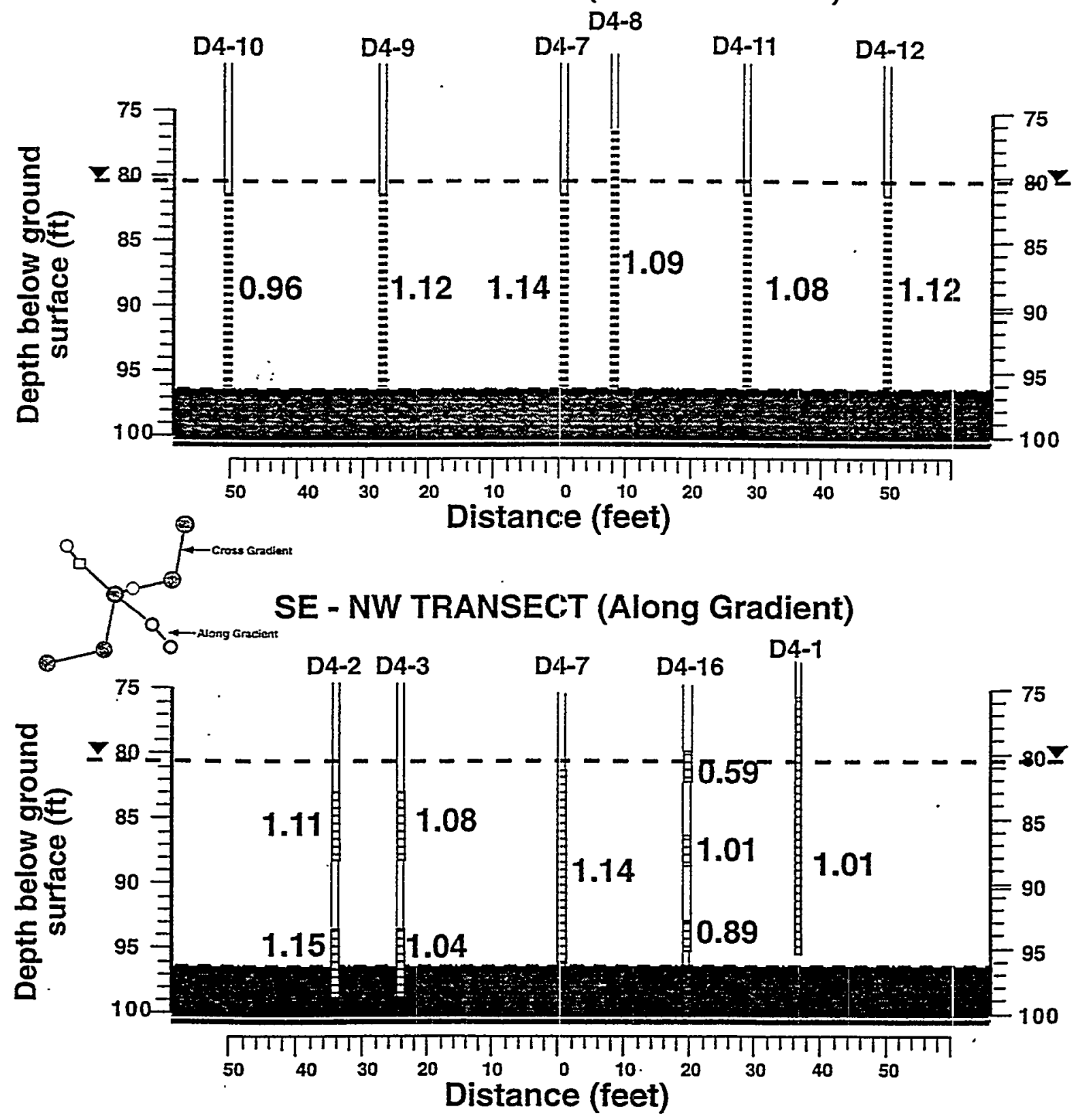

Figure 3.3. Cross-Section of Baseline Hexavalent Chromium at the 100-D Area ISRM Site 


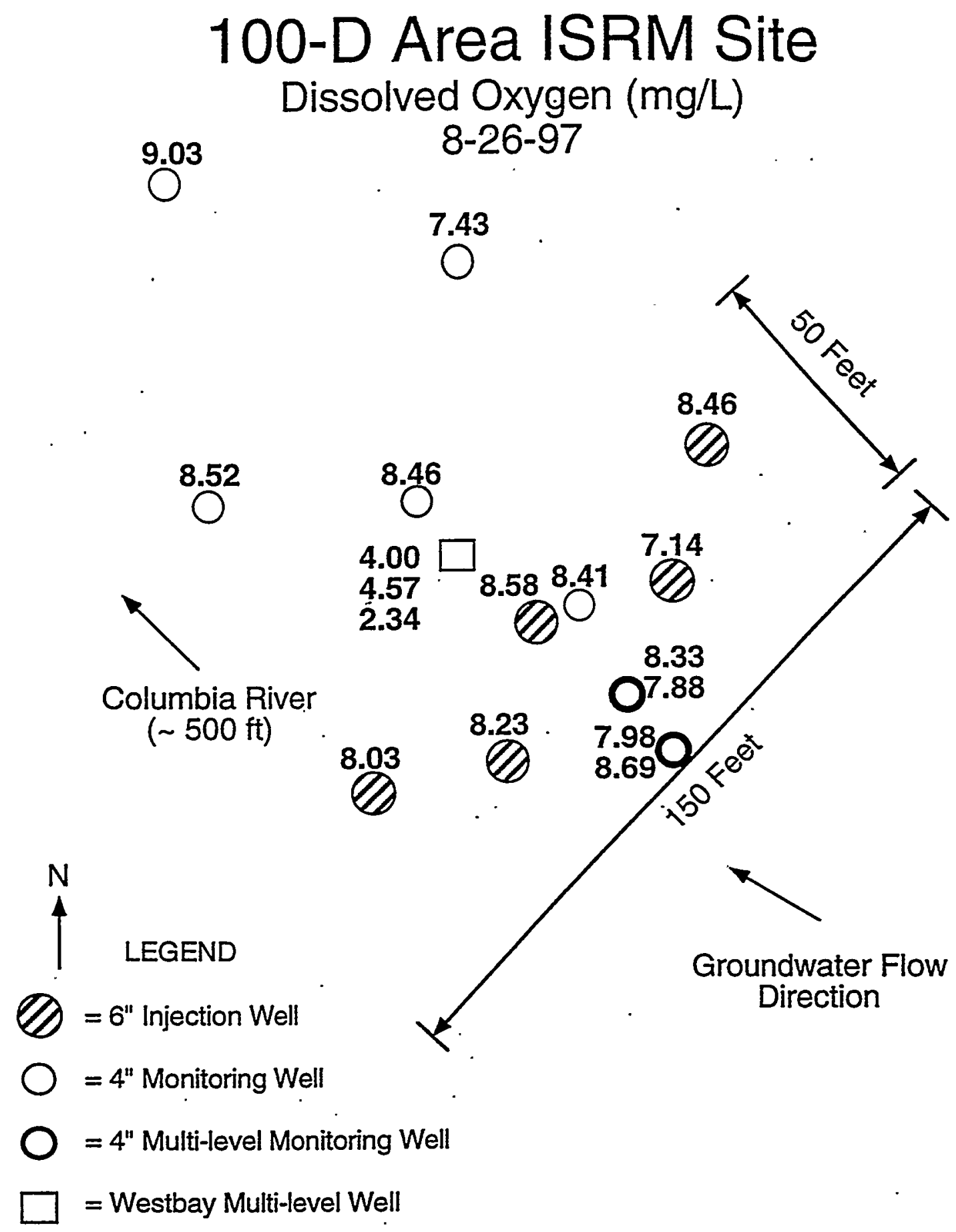

Figure 3.4. Baseline Dissolved Oxygen Concentrations at the 100-D Area ISRM Site 


\subsection{Bench-Scale Studies}

Bench-scale studies were conducted to characterize the aquifer sediments at the site and to quantify geochemical redox reactions that occur when dithionite is injected into these sediments. Results of these experiments were used aid in the design of the 100-D dithionite injection/ withdrawal experiments and for predicting long-term performance. The main objectives of this study were to determine the mass of reducible iron in the 100-D ISRM site sediments and the rate of this reduction and subsequent sediment oxidation. The sediment reduction rate controls the amount of time required for the dithionite solution to fully react with sediments, so it affects the reductant injection rate and lag time after injection and before the solution is extracted from the aquifer sediments. Column experiments were conducted in which reduced sediment was oxidized with oxygen-saturated water to provide an additional measure of 1 ) the mass of reduced iron and 2) the oxidation rate of the sediment. Laboratory experiments that were used to meet these objectives included 1) sediment reduction in batch (static) systems, 2) sediment reduction in 1-D columns, and 3) sediment oxidation in 1-D columns. Multiple reaction modeling of the static systems and reactive transport modeling of the dynamic systems was conducted to quantify the reactant masses and reaction rates.

A secondary objective of the bench-scale studies was to develop an understanding of the changes that occur in iron phases during reduction and oxidation. This information is used to predict how efficiently the sediment can be re-reduced and whether the mobility of iron or other metals becomes an important issue during the redox life cycle. Experimental techniques used to meet these objectives included chemical analysis of iron mineral and amorphous phases in untreated, reduced, and reduced/oxidized sediment and chemical analysis of liquid effluent for metals during reduction and oxidation column experiments.

\subsection{Iron Geochemistry During Reduction and Oxidation}

The proposed remediation technology used in this study introduces a reductant (sodium dithionite buffered at high $\mathrm{pH}$ ) into the contaminated sediment (typically 24 to 60 hours) for a short time to reduce Fe(III) oxides present to aqueous or surface-bound Fe(II). The reduced Fe(II) . appears to be present in several different phases: adsorbed $\mathrm{Fe}(\mathrm{II})$, structural $\mathrm{Fe}(\mathrm{II})$, and $\mathrm{Fe}$ (II)carbonate (siderite). The reaction that theoretically describes a single phase of iron that is reduced by sodium dithionite

$$
\mathrm{S}_{2} \mathrm{O}_{4}^{-2}+2 \mathrm{Fe}^{3+} \Leftrightarrow 2 \mathrm{Fe}^{2+}+\mathrm{SO}_{3}^{-2}+2 \mathrm{H}^{+}
$$

indicates that the forward rate is a function of the dithionite concentration and the square of the

reducible iron concentration. Experimental evidence indicates that a small fraction of the reducible iron sites was additionally affected by diffusion (i.e., slow physical access to surface sites) (described in Section 4.3). Based on this result, a diffusion step was added for a fraction of the iron sites

$$
\mathrm{S}_{2} \mathrm{O}_{4}^{-2}+2 \mathrm{Fe}^{3+} \Longleftrightarrow 2 \mathrm{Fe}^{2+}+\mathrm{SO}_{3}{ }^{-2}+2 \mathrm{H}^{+}
$$


where the total number of oxidized or reduced iron sites is the sum of sites in reactions 1 and 2. In cases where the mass of iron is far in excess of the dithionite, this reaction can be reduced to a first-order reaction that assumes that $\mathrm{Fe}^{3+}$ remains constant:

$$
\mathrm{S}_{2} \mathrm{O}_{4}{ }^{-2} \Longleftrightarrow 2 \mathrm{Fe}^{2+}+\mathrm{SO}_{3}^{-2}
$$

Another reaction occurs in the system that describes the disproportionation of dithionite in contact with sediment:

$$
2 \mathrm{~S}_{2} \mathrm{O}_{4}{ }^{-2}+\mathrm{H}_{2} \mathrm{O} \Leftrightarrow \mathrm{S}_{2} \mathrm{O}_{3}^{-2}+2 \mathrm{HSO}_{3}^{-}
$$

The oxidation of the adsorbed and structural $\mathrm{Fe}(\mathrm{I})$ in the sediments of the permeable redox barrier occurs naturally by the inflow of dissolved oxygen through the barrier but can additionally be oxidized by contaminants that may be present, such as chromate. The theoretical oxidation of reduced iron in pure mineral phases is relatively well described with the following reactions. $\mathrm{Fe}(\mathrm{III})$ species that are known to exist in the dithionite-reduced Hanford 100-D sediments include adsorbed $\mathrm{Fe}(\mathrm{II})$ and siderite $\left[\mathrm{Fe}(\mathrm{II}) \mathrm{CO}_{3}\right]$. Theoretically, a single mole of electrons is consumed as a mole of these species is oxidized:

$$
\begin{aligned}
& \mathrm{Fe}^{3+}+e^{-} \Leftrightarrow \mathrm{Fe}^{2+} \\
& \mathrm{Fe}(\mathrm{OH})_{3}(\mathrm{~s})+3 \mathrm{H}^{+}+e^{-} \Leftrightarrow \mathrm{Fe}^{2+}+3 \mathrm{H}_{2} \mathrm{O} \\
& \mathrm{Fe}(\mathrm{OH})_{3}(\mathrm{~s})+2 \mathrm{H}^{+} \mathrm{HCO}^{3-}+e^{-} \Longleftrightarrow \mathrm{FeCO}_{3}(\mathrm{~s})+3 \mathrm{H}_{2} \mathrm{O}
\end{aligned}
$$

The use of dissolved oxygen as an oxidant is generally divided into two electron sequences, which, combined,

$$
\mathrm{O}_{2}+4 \mathrm{H}^{+}+4 e^{-} \Leftrightarrow \mathrm{H}_{2} \mathrm{O}
$$

indicate 4 moles of electrons are available per mole of $\mathrm{O}_{2}$ consumed. The rate of this reaction (8) has generally been observed to be first order. Experimental evidence indicates that the oxygenation of $\mathrm{Fe}(\mathrm{II})$ in solutions $(\mathrm{pH}>5)$ is generally found to be first order with respect to $\mathrm{Fe}(\mathrm{II})$ and $\mathrm{O}_{2}$ concentration and second order with respect to $\mathrm{OH}$. Therefore, approximately 4 moles of $\mathrm{Fe}$ (II) are oxidized per mole of $\mathrm{O}_{2}$ consumed (reactions 8-10) and the rate increases 10-fold for a unit increase in $\mathrm{pH}$. At oxygen-saturated conditions $\left(8.2 \mathrm{ppm} \mathrm{O}_{2}\right), 1.02 \mathrm{mmol} \mathrm{L}^{-1}$ $\mathrm{Fe}(\mathrm{II})$ is consumed.

The oxidation of reduced iron in the natural sediment appears to be more complex than a single oxidation reaction and is likely controlled by both chemical and physical processes. The combination of reactions 5 and 8 yields

$$
4 \mathrm{Fe}^{2+}+\mathrm{O}_{2}+4 \mathrm{H}^{+} \Leftrightarrow 4 \mathrm{Fe}^{3+}+\mathrm{H}_{2} \mathrm{O}
$$


which describes the oxidation of the main reduced iron species that appears to be present in the reduced sediments [adsorbed $\mathrm{Fe}(\mathrm{II})$ ]. Experimental evidence during iron oxidation experiments indicates that a second type of reduced iron species is present (siderite) in minor concentrations. In addition, a minor fraction of reduced iron sites (presumed to be siderite) appears to be more slowly oxidized, so a second oxidation reaction

$$
4 \mathrm{Fe}^{2+}+\mathrm{O}_{2}+4 \mathrm{H}^{+} \Leftrightarrow 4 \mathrm{Fe}^{3+}+\mathrm{H}_{2} \mathrm{O}
$$

was considered in reaction models used. Both of these reactions (9 and 10) show that 4 moles of $\mathrm{Fe}(\mathrm{II})$ is consumed per mole of oxygen consumed.

This redox treatment technology has previously been applied (at Hanford) to a groundwater site containing chromium contamination. In that case, $\mathrm{Cr}(\mathrm{VI})$ is reduced to $\mathrm{Cr}(\mathrm{III})$ by $\mathrm{Fe}(\mathrm{II})$ oxidation. In general, contaminants such as chromate or TCE are present in low concentrations such that iron oxidation (i.e., remediation barrier destruction) is dominated by dissolved oxygen in water. However, if chromate or TCE are present at high concentration, their impact on iron oxidation needs to be considered. For chromate:

$$
\mathrm{HCrO} 4-+7 \mathrm{H}++3 \mathrm{e}-\Leftrightarrow \mathrm{Cr} 3++4 \mathrm{H} 2 \mathrm{O}
$$

3 moles of electrons are consumed per mole of chromate reduced. The reduction of one mole of chromate oxidizes three moles of Fe(II) [reactions 5 and 11], or $41 \mathrm{mg} \mathrm{L}^{-1}$ chromate is needed to oxidize the equivalent mass of $\mathrm{Fe}(\mathrm{II})$ as water saturated with dissolved oxygen $\left[1.05 \mathrm{mmol} \mathrm{L}^{-1}\right.$ $\mathrm{Fe}(\mathrm{II})]$. Because the highest chromate concentration found in the Hanford 100D area unconfined aquifer is $2 \mathrm{ppm}$, its influence on iron oxidation is not significant.

\subsection{Batch and Column Experimental Methods}

A series of batch and column experiments was conducted to determine the mass and rate of reduction of iron in sediment by the reduction solution (sodium dithionite $\mathrm{pH}$-buffered to 11.0). Batch sediment reduction experiments consisted of a series of septa-top vials in which $6.0 \mathrm{~g}$ of sediment was mixed with $10 \mathrm{~mL}$ of dithionite solution for a specified time (minutes to tens of hours), then the solution was filtered and analyzed for dithionite remaining in solution. The dithionite solution contained $0.06 \mathrm{~mol} \mathrm{~L}^{-1}$ sodium dithionite $\left(\mathrm{Na}_{2} \mathrm{~S}_{2} \mathrm{O}_{4}\right), 0.24 \mathrm{~mol} \mathrm{~L}^{-1} \mathrm{~K}_{2} \mathrm{CO}_{3}$, and $0.024 \mathrm{~mol} \mathrm{~L}^{-1} \mathrm{KHCO}_{3}$. These batch experiments were conducted in an anaerobic chamber to prevent the dithionite from reacting with oxygen. The dithionite concentration was measured by UV absorption at $315 \mathrm{~nm}$. Two reactions were studied, the reduction of iron in the sediment, which has a half-life of $\sim 5$ hours, and a disproportionation reaction, which has a half-life of 27 hours. Based on the rate of these reactions, batch reduction experiments were completed within 60 hours.

Sediment reduction studies were also conducted in 1-D columns. These experiments consisted of injecting the dithionite solution at a steady rate into a sediment column and measuring the concentration of dithionite over time in the effluent for 48 to 120 hours. The flux rate was chosen to achieve specific residence times of the dithionite solution in the column ( 2 to 14 hours) relative to the reaction rates. The dithionite concentration in the effluent was measured once per hour using an automated fluid system and data logging equipment. 
The rate at which the dithionite-reduced sediment was oxidized was studied in 1-D columns. These experiments consisted of injecting oxygen-saturated $\left(8.2 \mathrm{mg} \mathrm{L}^{-1}\right.$ or $\left.256 \mu \mathrm{mol} \mathrm{L} \mathrm{L}^{-1}\right)$ synthetic groundwater at a steady rate into a reduced sediment column and measuring the concentration of dissolved oxygen over time in the effluent for 100 to 400 hours. The flux rate was chosen to achieve specific residence times of the dissolved oxygen in the column relative to the oxidation rate(s) of the sediment.

\subsection{Sediment Reduction Results}

The mass of reducible iron was calculated from measurements of dithionite breakthrough in column experiments using eight different sediments from four wells in the 100-D area (column experiments D6-D17, Table 4.1). In each experiment, the mass of dithionite presumed to reduce iron was calculated from the total dithionite mass loss in the experiment minus the loss due to disproportionation (reaction 4). Sediments used in experiments showed an average of $31.8 \pm 5.6$ $\mu \mathrm{mol} / \mathrm{g}$ for the sediments tested, which were all the $<4 \mathrm{~mm}$ sieved fraction of the entire field sediment. With the assumption that the $>4 \mathrm{~mm}$ fraction of the sediment has no reactive surfaces, the 100-D sediments averaged $11.0 \pm 3.0 \mu \mathrm{mol} / \mathrm{g}$ of reducible iron. Column experiments in which sediment was subsequently oxidized with dissolved oxygen in water (column experiments D18-D31, Table 4.1) indicated that 47 to $81 \%$ of the reduced iron was oxidized.

Using the average values for physical properties at the 100-D Area (porosity and bulk density), the $31.8 \pm 5.6 \mu \mathrm{mol}$ reducible Fe per gram of soil has a treatment capacity of $171 \pm 46$ pore volumes of groundwater ( $8 \mathrm{mg} / \mathrm{L}$ dissolved oxygen and $1 \mathrm{mg} / \mathrm{L}$ hexavalent chromium). Assuming this average was attained for a $50 \mathrm{ft}$ width at the 100-D Area site, the predicted longevity of the 100-D Area ISRM permeable treatment zone is $23 \pm 6$ years (using a $1 \mathrm{ft} / \mathrm{d}$ groundwater velocity). Sediment samples collected from the treatment zone from core holes are required to measure the reductive capacity achieved during emplacement and are planned for FY 1999.

The rate of iron reduction by the dithionite solution was determined from batch and column experimental data and subsequent modeling. The reduction rate of surface iron by sodium dithionite in batch systems (Figure 4.1a) has shown that the third-order reaction (reaction 1) for the reduction of iron is needed to describe the data. The dynamic nature of the reduction was not fully described using the first-order approach (reaction 3). The rate of iron reduction in this batch experiment was 4.5 hours.

Reduction of iron in sediment during transport is shown by a 1-D column experiment (Figure 4.1b), in which the initial fast breakthrough of dithionite is followed by a slow approach to equilibrium. Reactions (1) and (4) were needed to fit these data (i.e., a simpler approach, reactions 3 and 4, could not fit the data). In addition to the two chemical reactions, an additional slow physical approach to equilibrium was needed. In a column experiment of the breakthrough of dissolved oxygen in a nonreduced sediment (not shown), the slow approach to equilibrium (relative to a tracer) indicated that a fraction of the sites were slower to be accessed. Based on this result, a diffusion step was added for a fraction of the iron sites (reaction 2), where the total number of oxidized or reduced iron sites is the sum of sites in reactions 1 and 2. The reduction rate for the major fraction of the reducible iron sites averaged 5.5 hours in column experiments (from Table 4.1). 
Table 4.1. Reaction Mass and Rates from Column Experiments

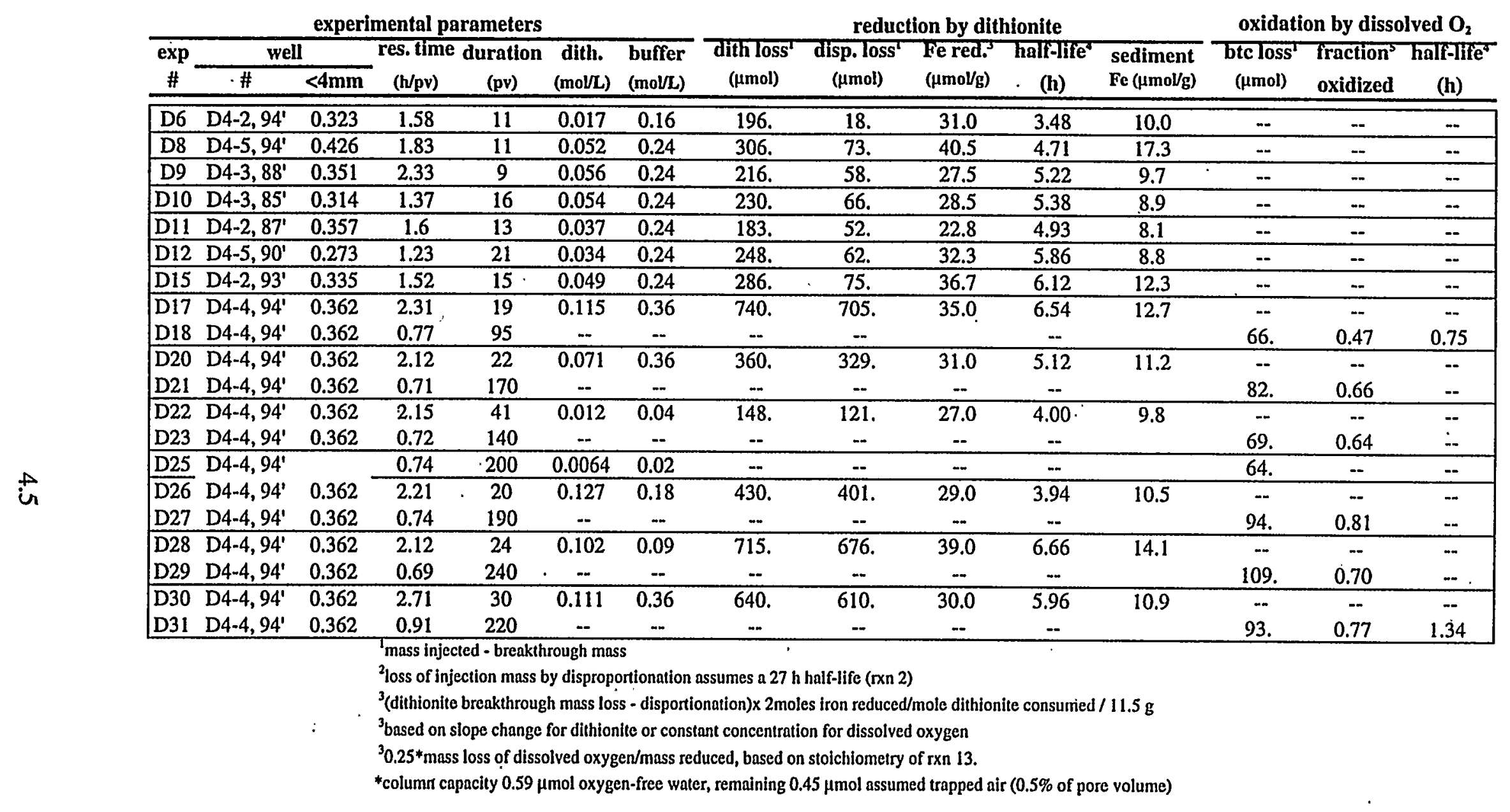


a)

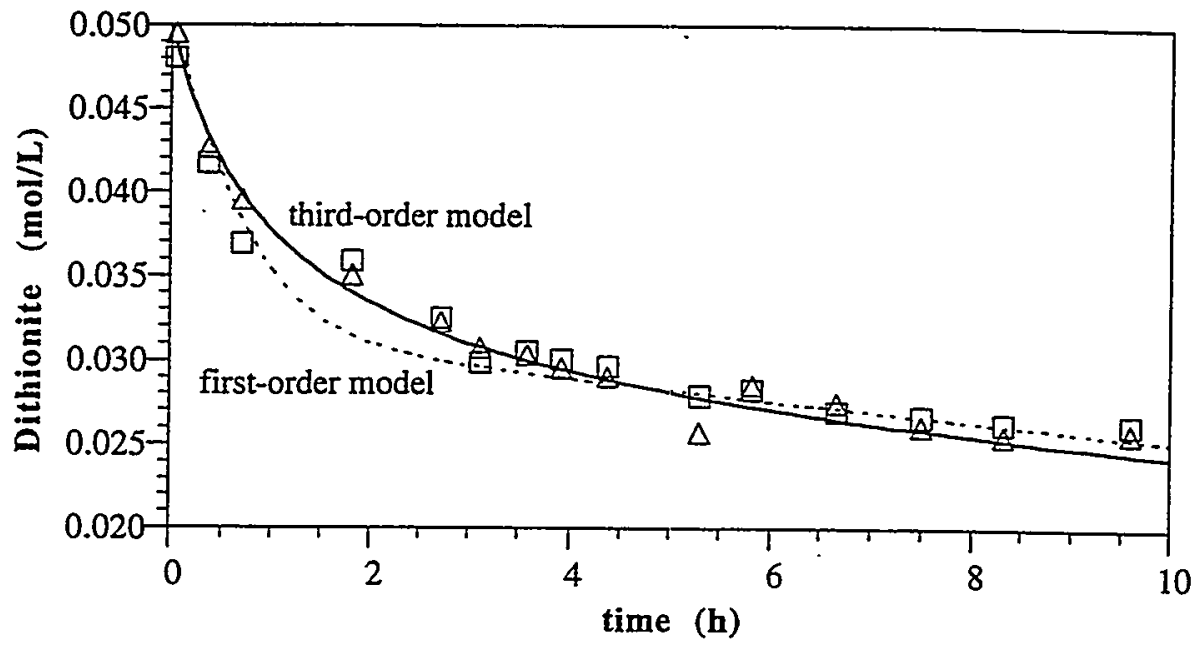

b)

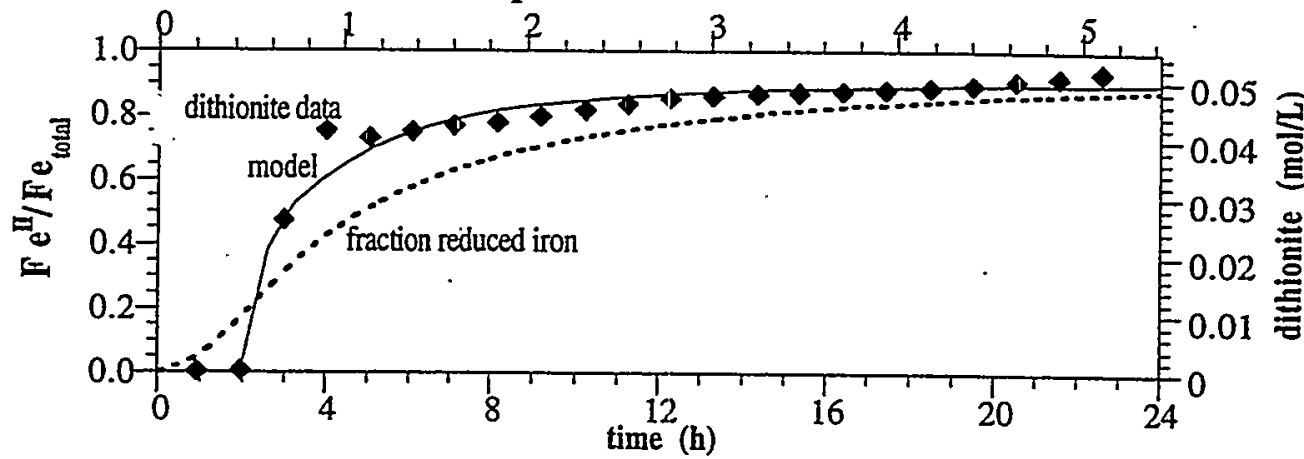

Figure 4.1. Reduction of 100-D Sediment by a Sodium Dithionite Treatment in a) batch systems with model fits with reaction 1 (solid line) and model 3 (dashed line); both fits included the desproportionation reaction 4; b) 1-D columns with a model fit using reaction 1 (iron reduction) and reaction 4

Sediment samples from well D4-4 were extensively studied in a series of experiments in which the dithionite concentration and $\mathrm{pH}$ buffer concentration were varied. Experiments varying dithionite concentration showed that considerably more time is required to reduce sediment using low dithionite concentrations, so high dithionite concentrations $(0.03$ to $0.1 \mathrm{~mol} / \mathrm{L})$ were recommended for the field injections. In other column experiments, the $\mathrm{pH}$ buffer concentration was varied from one to four times the dithionite concentration. Theoretically, two moles of $\mathrm{H}^{+}$ions are released per mole of iron reduced (reaction 1), so $\mathrm{pH}$ could be maintained with the $\mathrm{pH}$ buffer concentration twice the dithionite concentration. Earlier laboratory and field experiments showed the importance of maintaining a high $\mathrm{pH}$ in the injection solution because the disproportionation of dithionite (reaction 3 ) is considerably faster at lower $\mathrm{pH}$. Column experiments with a $\mathrm{pH}$ buffer concentration of four times the dithionite concentration showed less than a $0.3 \mathrm{pH}$ unit decrease during dithionite injection. With the $\mathrm{pH}$ buffer at twice the dithionite concentration, a $1.5 \mathrm{pH}$ unit decrease was observed, and when the $\mathrm{pH}$ buffer concentration was the same as the dithionite concentration, the $\mathrm{pH}$ dropped from 11.0 to 3.8. These results indicated that the field-scale dithionite injection would most efficiently reduce the sediment when the $\mathrm{pH}$ buffer was four times the dithionite concentration. 


\subsection{Sediment Oxidation Results}

Oxidation column experiments were used to determine sediment oxidation rates and predict the longevity of the redox barrier in the field. These experiments showed that a large fraction of reduced sites are oxidized within 100 to 250 pore volumes (of dissolved oxygen), but a small fraction of sites were oxidized more slowly. This concept is illustrated by three oxidation column experiments at differing pore water velocities (Figures 4.2a-c) in which the slowest velocity (Figure 4.2a) shows dissolved oxygen remaining low for 370 pore volumes, after which oxygen saturation is quickly achieved. This equilibrium breakthrough curve shape is caused by the oxidation reaction rate being considerably faster than the residence time in the column (60 hours); therefore, dissolved oxygen had time to fully react with reduced iron. At a velocity in which dissolved oxygen only partially reacts with reduced iron (Figure $4.2 b$, residence time 1.9 hours), dissolved oxygen breakthrough rises after 100 pore volumes, then slowly approaches oxygen saturation. At a higher velocity (Figure 4.2c, residence time 0.2 hour), partial oxygen breakthrough occurs almost immediately followed by the slow approach to oxygen saturation over hundreds of pore volumes. A rough approximation of the sediment oxidation rate half-life is 0.25 hour, based on the dissolved oxygen plateau in Figure 4.2c (10-60 pore volumes).

The oxidation of reduced iron in the natural sediment appears to be more complex than a single oxidation reaction, and is likely controlled by both chemical and physical processes. A reactive transport model used to simulate the oxidation of the sediment with reaction (1) could not fit the dissolved oxygen breakthrough data shown in Figure 4.2c, which contains multiple slope changes. However, with the addition of a second type of reduced iron (reaction 2) then dynamic breakthrough curve shape can generally be fit using both reactions (line shown in Figure 4.2c). This simulation had $20 \%$ of the reduced iron is modeled with reaction 2 with a considerably slower rate. The breakthrough curve shape is not well fit initially ( 0 to 20 pore volumes), and a more complex approach for reaction 1 is needed. Breakthrough curve tailing in a column experiment of purely dissolved oxygen in a nonreduced sediment (not shown) for 5-6 pore volumes indicates diffusional limitations accessing a fraction of the pore volume. This physical tailing for dissolved oxygen could explain the tailing observed for dissolved oxygen for the fast oxidation reaction (Figure $4.2 \mathrm{c}, 10-40$ pore volumes). Measurement of the column effluent Eh (Figure 4.2d, same experiment as Figure 4.2b) also provides an indication of the complexity of the oxidation of the sediment.

\subsection{Mineralogical Changes During Dithionite Treatment}

Iron extractions were conducted on unreduced, reduced, and reduced/oxidized sediments to specifically determine the changes in iron phases that occur during reduction and subsequent oxidation of the sediment. The total extractable $\mathrm{Fe}(\mathrm{II})$ and $\mathrm{Fe}(\mathrm{III})$ in the $<4 \mathrm{~mm}$ fraction of Hanford 100-D sediments was $76 \pm 25 \mu \mathrm{mol} / \mathrm{g}$, of which 70 to $80 \%$ was Fe(III) oxides. The amorphous Fe(III) phases ranged from 30 to $60 \%$ of the total $\mathrm{Fe}$ (III) oxides. Extractions conducted on reduced sediments showed a measurable decrease in the amorphous $\mathrm{Fe}(\mathrm{III})$ phases, a large increase in the adsorbed $\mathrm{Fe}(\mathrm{II})$, and a small increase in $\mathrm{Fe}(\mathrm{II}) \mathrm{CO}_{3}$. ICP-MS analysis of the redox reactive fraction of sediment showed that iron species accounted for $97 \%$ of the reactivity and $\mathrm{Mn}$ species the remaining 3\%. Oxidation of the sediment in a column (600 pore volumes of 


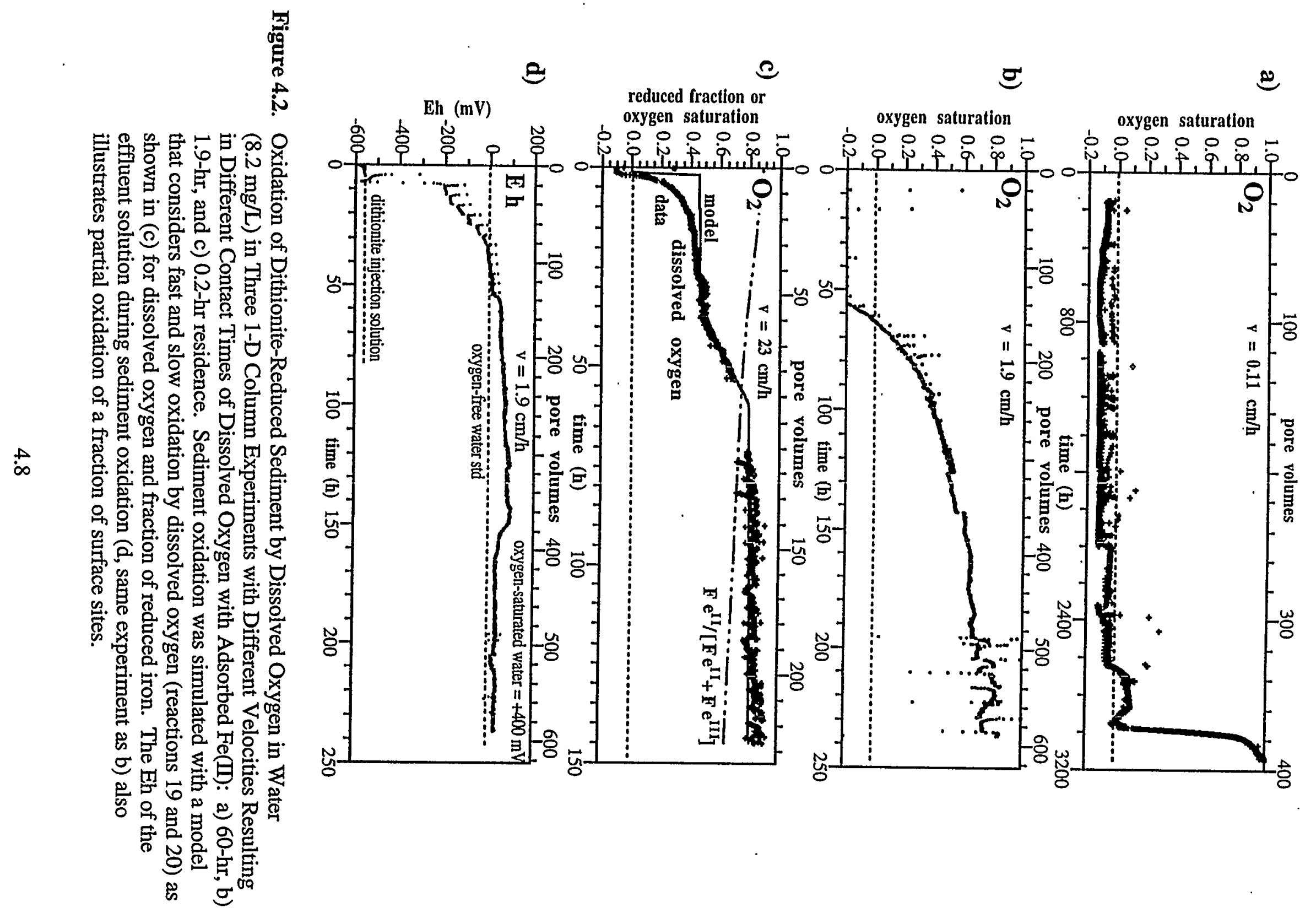


oxygen-saturated water) resulted in a loss of all the adsorbed $\mathrm{Fe}(\mathrm{II})$, little change in $\mathrm{Fe}(\mathrm{II}) \mathrm{CO}_{3}$, and an increase in both amorphous and crystalline Fe(III) oxides. Therefore, the dithionite treatment appears to mainly dissolve amorphous $\mathrm{Fe}(\mathrm{Im})$ oxides and create mainly adsorbed $\mathrm{Fe}(\mathrm{II})$. The dithionite treatment appears to reduce only a fraction of the available $\mathrm{Fe}(\mathrm{III})$ oxides. The Fe(II) is highly adsorbed, as $<0.1 \%$ was measured in the effluent from several column experiments after 300 pore volumes. Iron extractions indicated up to a $10 \%$ loss of total iron in the sediment after 600 pore volumes of water were injected through the sediment. These results indicate that a reduced sediment barrier can be re-reduced with only a small loss in iron capacity. Sediment from the 100-H area was, in fact, reduced/oxidized twice and had a $6 \%$ loss in reduced iron in the second reduction.

\subsection{Immobilization of Chromate}

An oxidation column experiment was conducted to test the immobility of chromate because the emplacement of the redox barrier in the 100-D area of the Hanford Site is to prevent chromate present in the shallow aquifer from reaching the Columbia River. Chromium is a redox-sensitive contaminant that will be immobilized at the redox barrier as a result of precipitation reactions when $\mathrm{Cr}(\mathrm{VI})$ is reduced to the less soluble $\mathrm{Cr}(\mathrm{III})$. Although the reduction of chromate oxidizes $\mathrm{Fe}(\mathrm{II})$, because most chromate contamination is $<5 \mathrm{ppm}$, dissolved oxygen is mainly responsible for oxidizing the $\mathrm{Fe}(\mathrm{II})$. Chromate would need to be present at a concentration of $120 \mathrm{mg} / \mathrm{L}$ to have an equivalent ability to oxidize the redox barrier as dissolved oxygen. Therefore, while chromate oxidation of the reduced sediment and the subsequent effect on uranium transport was not considered likely, because chromate is a stronger oxidant than dissolved oxygen, it may have some impact on the barrier oxidation rate even if present at a low concentration. Chromate transport behavior was also studied because of the relative difference in mobility compared with uranium species. $\mathrm{Cr}$ (III) is not readily oxidized to $\mathrm{Cr}(\mathrm{VI})$ when the redox barrier is ultimately oxidized. To test this difference in behavior, a long-term column experiment was conducted in which $\mathrm{Cr}(\mathrm{VI})$ was injected through reduced sediment and the remobilization behavior monitored once the sediment was oxidized.

The column experiment was conducted by injecting near-oxygen-saturated water (average of 6.0 $\mathrm{mg} \mathrm{L}^{-1}$ ) and $2.3 \mathrm{mg} \mathrm{L}^{-1} \mathrm{Cr}$ (as chromate) into a reduced Hanford 100-H sediment until oxidized. This 4,000hour (6-month) experiment was conducted with Hanford formation sediment that was treated with the reductant in a method similar to that used at the field scale (sodium dithionite injected for 12 hours, then a 48-hour no-flow interval). This experiment confirmed the expected behavior of $\mathrm{Cr}$ (III) species. Chromate was generally immobilized in the reduced sediment until the sediment was oxidized (at $\sim 800$ pore volumes), after which time the chromate effluent was equivalent to the influent concentration. The mass of injected chromate $\left(\mathrm{CrO}_{4}{ }^{2}\right)(42.7 \mathrm{mg})$ was not recovered even after 4,000 hours or 1500 pore volumes of oxic water is flushed through the sediment (effluent was $20.7 \mathrm{mg}$ or $48 \%$ ) (Figure 4.3). This was expected due to the slow dissolution rate for solid $\mathrm{Cr}(\mathrm{OH})_{3}$ in oxic water. 


\subsection{Trace Metals Mobilization}

During laboratory-scale column experiments, effluent samples were taken during Fort Lewis sediment reduction (about 10 pore volumes), and during Ft Lewis sediment oxidation (550 pore volumes) to assess the potential migration of trace metals (22 metals including $\mathrm{Ni}, \mathrm{Cu}, \mathrm{As}, \mathrm{Cd}$, $\mathrm{Sn}, \mathrm{Sb}, \mathrm{Ba}, \mathrm{Cr}$ ). Some metals are elevated in aqueous concentration during sediment reduction because of increased solubility in the reducing environment, but all trace metals dropped to preinjection levels within 5 pore volumes of injection of oxygen-saturated water, which is the basis of the withdrawal of 3-5 pore volumes of the amount of water injected during a dithionite injection in field scale injections. The concentrations of the major metals injected $(\mathrm{K}+$ from the $>0.2 \mathrm{~mol} / \mathrm{L} \mathrm{K} 2 \mathrm{CO} 3$ and $\mathrm{Na}+$ from the sodium dithionite) took considerably greater number of pore volumes to asymtotically approach pre-injection levels. A more complete summary of this trace metal migration during reduction and oxidation will be reported in a subsequent report.

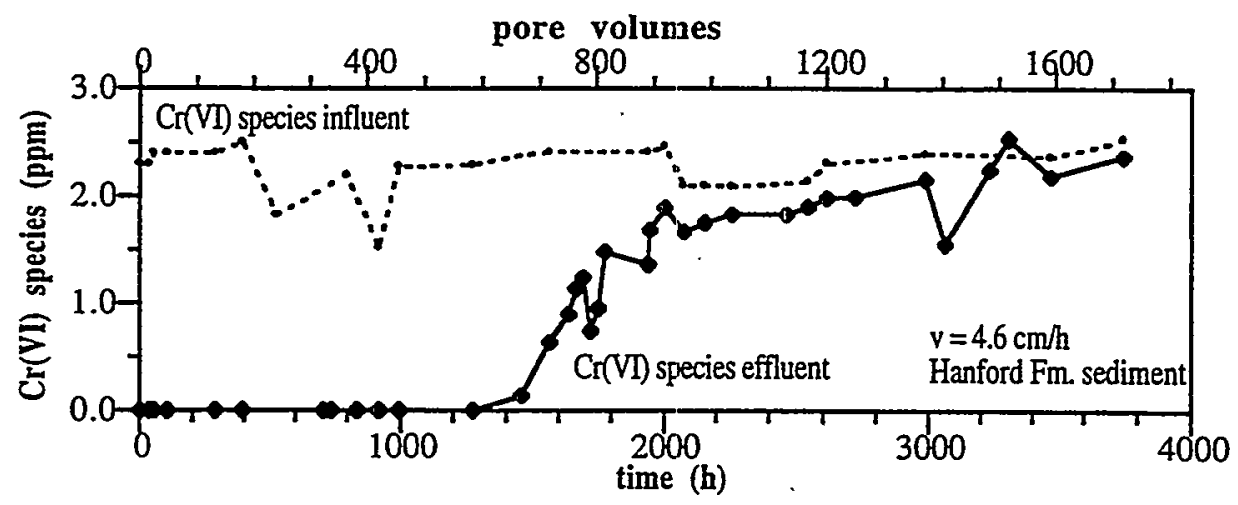

Figure 4.3. 1-D Column Experiment Results Showing the Reduction and Immobilization of $\mathrm{Cr}$ (VI) Species When Hanford Sediment is Reduced (first 800 pore volumes), and Lack of Dissolution of the Immobilized $\mathrm{Cr}$ (III0 Species in Oxic Sediments for a Subsequent 1000 Pore Volumes 


\subsection{Emplacement Process}

\subsection{Emplacement Strategy}

The ISRM emplacement process uses an injection/withdrawal, or "push/pull," method to create the permeable treatment zone. The emplacement process is conducted in three stages, injection, reaction, and withdrawal. In the injection stage, the reagent (sodium dithionite with a potassium carbonate/bicarbonate $\mathrm{pH}$ buffer to enhance dithionite stability) is injected into the injection/ withdrawal well. Dithionite concentrations and other parameters are measured on the injection stream and in the monitoring wells at nearby radial distances. The duration of the injection stage is about 10 hours. When the injection is complete, a reaction stage follows, providing time for the dithionite and iron reactions to proceed. The duration of the reaction stage is about one to two days. In the final stage (withdrawal), unreacted reagent and reaction products are extracted from the aquifer by pumping from the same well used for the injection. The duration of the withdrawal stage is about one week. Pumping rates used in the withdrawal stage are less than the injection rate (15-20 gpm for withdrawal; $~ 60$ gpm for injection) because of excessive drawdown in the well. The withdrawal stage is also longer because up to five "injection volumes" are withdrawn to recover a majority of the reaction products (i.e., minimize residual chemicals in the aquifer). Dithionite concentrations and other water quality parameters are monitored in the nearby wells and in the extraction stream during both the reaction and withdrawal stages.

This push-pull emplacement process creates a roughly cylindrical zone of reduced iron ( $\mathrm{Fe}^{2+}$ ) centered around the injection/withdrawal well. The actual shape depends on the spatial distribution of hydraulic properties (permeability and porosity) within the aquifer (heterogeneities). The exact shape is not fully characterized due to the limited number of monitoring wells installed. To create a long barrier to intercept a contaminated groundwater plume, a series of overlapping injection wells is used to coalesce these cylindrical zones of reduced iron (see Figures 1.5 and 1.6).

For the 100-D Area ISRM treatability test, five injection/withdrawal wells were used to create a treatment zone $150 \mathrm{ft}$ long, $50 \mathrm{ft}$ wide, and $15 \mathrm{ft}$ thick (the entire thickness of the unconfined aquifer). The three main injection/withdrawal wells (D4-10, D4-7, and D4-12) are spaced $50 \mathrm{ft}$ apart. The two overlapping injection/withdrawal wells (D4-9 and D4-11) are offset from the line of main injection/withdrawal wells and are spaced $28 \mathrm{ft}$ radially from the adjacent main injection/withdrawal wells.

This overlapping well design serves two main purposes; it not only reduces the risk of gaps in the permeable treatment zone but also provides for monitoring the extent of dithionite concentrations in the main injection/withdrawal wells. The 50-ft radial spacing of the main dithionite injection/withdrawal wells is too large to adequately monitor dithionite concentrations in adjacent wells for establishing the extent of the reduced zone created around an injection/ withdrawal well. Practical limitations of the push-pull method based on the volumes required, length of time, and the instability/decay of dithionite limit the radial influence around a single injection/withdrawal well. In addition, increasing the radius of influence for a dithionite injection increased not only the well spacing but also the barrier width, which may result in 
significant overdesign and waste for a given application. The other benefits of the push-pull approach are that it provides the maximum percentage of recovery of injected solute, enhanced reagent penetration of low permeability zones due to changing hydraulic gradients during the injection/reaction/withdrawal stages, and ease of operation. Alternative emplacement approaches that do not have these radial geometry limitations are horizontal wells or simultaneous operation of injection/ withdrawal wells (e.g., dipoles).

\subsection{Emplacement Description}

A concentrated sodium dithionite, potassium carbonate, and potassium bicarbonate solution is delivered to the ISRM site in a 4,000- to 7,000-gallon tanker truck (see Figure 4.2-3). The solution is chilled with nitrogen or argon gas filling the headspace of the tank to minimize contact with atmospheric oxygen. The dry chemicals are dissolved in water and loaded into the tanker truck at a chemical plant in Kalama, Washington. Once loaded, the reagent is trucked directly to the 100-D Area ISRM site for immediate injection. Two frac tanks (20,000 gallons each) at the site are prefilled with groundwater pumped from wells at the site for diluting the solution to the concentration required for injection. Two injection pumps and two flow meters are used for in-line mixing of the concentrated reagent with groundwater during the injection. As mentioned, a 4,000-gallon tank was used in the first two dithionite/injection withdrawal tests to offload the concentrated mixture from the tanker truck prior to injection. The remaining injections were conducted with one injection pump connected directly to the tanker truck.

A summary of the dithionite injection/withdrawal tests is given in Table 5.1. The results of the first test (D4-7) were used to refine the design for subsequent tests. For this purpose, the D4-7 test contained the greatest number of monitoring wells at sufficient radial distances for monitoring the emplacement. Two-hundred groundwater samples were collected during the D4-7 injection; a total of 500 were collected over the entire injection/reaction/withdrawal stages of the D4-7 test. These groundwater samples were measured, for electrical conductivity, $\mathrm{pH}$, temperature, dissolved oxygen, and dithionite in the mobile laboratories at the site. Archive samples were also collected for all these samples later analysis of anions and/or trace metals, if needed.

The D4-7 dithionite injection/withdrawal is described in the following section. Details on the modifications of subsequent tests based on these results are also described.

\subsection{Dithionite Injection/Withdrawal Test}

\subsubsection{Injection Stage}

The injection stage of the D4-7 dithionite injection/withdrawal test was started on September 29, 1997. The chemical reagent was injected into the aquifer at a rate of $60 \mathrm{gpm}$ for 10.4 hours, yielding a total injection volume of 37,300 gallons. Constant concentrations were maintained during the injection stage as follows: $0.09 \mathrm{M}$ sodium dithionite, $0.36 \mathrm{M}$ potassium carbonate, and $0.036 \mathrm{M}$ potassium bicarbonate. 
Table 5.1. Dithionite Injection/Withdrawal Summary

\begin{tabular}{|c|c|c|c|c|}
\hline $\begin{array}{c}\text { Injection } \\
\text { Well }\end{array}$ & Dates & $\begin{array}{c}\text { Volume } \\
\text { Injected } \\
\text { (gal) }\end{array}$ & $\begin{array}{c}\text { Dithionite } \\
\text { Concentration }^{(2)} \text {. } \\
(\mathrm{m})\end{array}$ & $\begin{array}{c}\text { Volume Withdrawn } \\
\text { (gallons) }\end{array}$ \\
\hline $\mathrm{D} 4-7$ & $9 / 29 / 97$ to $10 / 8 / 97$ & 37,300 reagent & $0.09 \mathrm{~m}$ for $10.4 \mathrm{hr}$ & $\begin{array}{l}154,500 \text { ( } 4.1 \text { injection } \\
\text { volumes). Disposed at ETF. }\end{array}$ \\
\hline D4-12 & $5 / 4 / 98$ to $5 / 13 / 98$ & $\begin{array}{l}29,500 \text { reagent } \\
6,500 \text { groundwater }\end{array}$ & $\begin{array}{l}0.1 \mathrm{~m} \text { for } 1.1 \mathrm{hr} \\
0.07 \mathrm{~m} \text { for } 6.5 \mathrm{hr}\end{array}$ & $\begin{array}{l}182,000 \text { ( } 5.0 \text { injection } \\
\text { volumes). } 36,000 \text { gallons to } \\
\text { purge water modutanks, } \\
\text { remainder purged to ground. }\end{array}$ \\
\hline D4-10 & $5 / 19 / 98$ to $6 / 5 / 98$ & $\begin{array}{l}29,500 \text { reagent } \\
8,400 \text { groundwater }\end{array}$ & $\begin{array}{l}0.1 \mathrm{~m} \text { for } 1.5 \mathrm{hr} \\
0.065 \mathrm{~m} \text { for } 6.5 \mathrm{hr}\end{array}$ & $\begin{array}{l}192,500 \text { (5.1 injection } \\
\text { volumes). } 38,000 \text { gallons to } \\
\text { purge water modutanks, } \\
\text { remainder purged to ground. } \\
\text { Note: pump failure during } \\
\text { withdrawal. }\end{array}$ \\
\hline D4-11 & $7 / 13 / 98$ to $7 / 23 / 98$ & 20,000 reagent & $0.06 \mathrm{~m}$ for $5 \mathrm{hr}$ & $\begin{array}{l}100,000 \text { ( } 5 \text { injection volumes) } \\
20,000 \text { gallons to purge water } \\
\text { modutanks, remainder purged } \\
\text { to ground. }\end{array}$ \\
\hline D4-9 & $7 / 13 / 98$ to $7 / 23 / 98$ & 20,000 reagent & $0.06 \mathrm{~m}$ for $5 \mathrm{hr}$ & $\begin{array}{l}100,000 \text { (5 injection volumes) } \\
20,000 \text { gallons to Pprge water } \\
\text { modutanks, remainder purged } \\
\text { to ground. }\end{array}$ \\
\hline
\end{tabular}

Breakthrough curves at the monitoring wells for dithionite concentrations and electrical conductivity (whose behavior was similar to the conservative bromide tracer) are provided in Appendix E. Arrival times in the monitoring wells were similar to the results measured in the bromide tracer test with well screened in the upper portion of the aquifer having significantly earlier breakthrough and much higher concentrations relative to wells screened in the lower portion of the aquifer.

In response to the 60-gpm injection rate, a significant injection mound formed in the unconfined aquifer where the water table elevation is raised above its pre-injection level, as shown in Figure 5.1. The extent of the injection mound is a function of the hydraulic properties of the aquifer, the injection rate, and the injection duration. The volume of water in the injection mound was approximately one-third of the total injection volume.

\subsubsection{Reaction Stage}

The reaction stage lasted 35 hours, between the end of the injection stage and the start of the withdrawal stage. Dithionite concentrations are monitored during the reaction stage and are useful to indicate the presence of reducible $\mathrm{Fe}(\mathrm{m})$ in the sediment. Because the rate of the dithionite/Fe(III) redox reaction is relatively fast ( $\sim 5-\mathrm{hr}$ half-life), high concentrations of dithionite that are still detected in wells after a significant number of half-lives have elapsed 


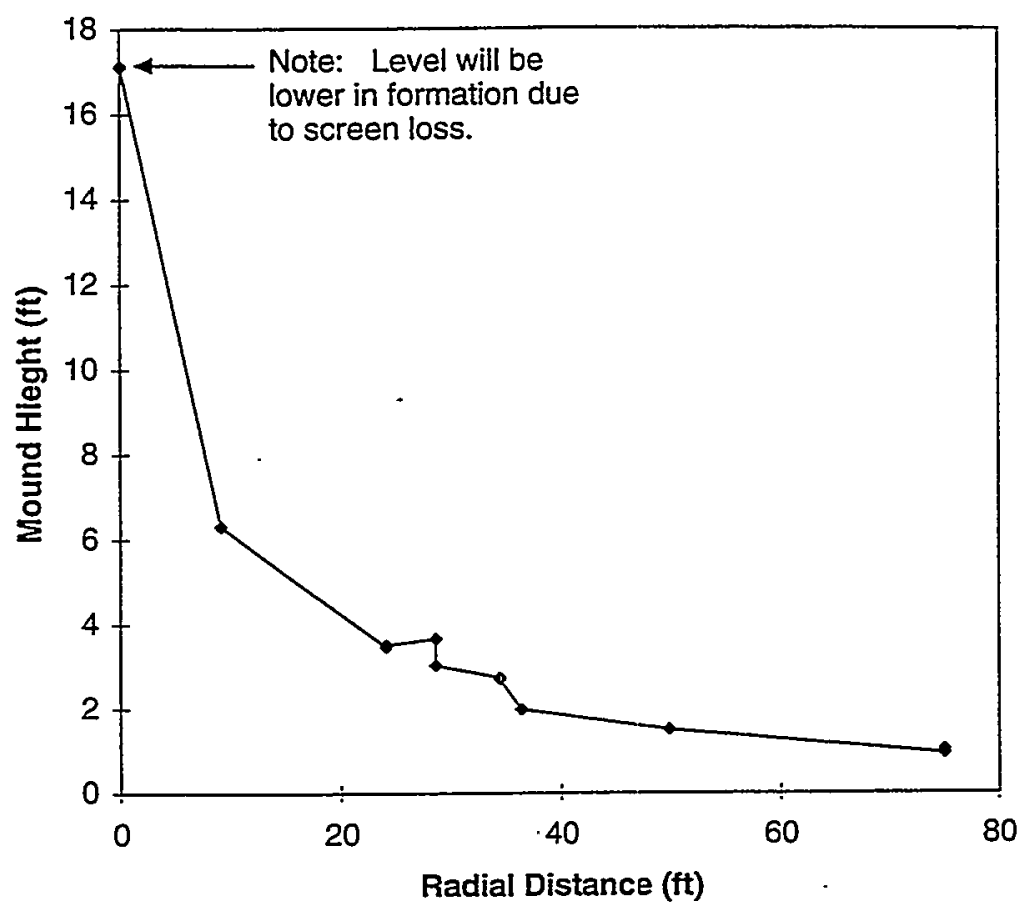

Figure 5.1. Extent of Injection Mound Formed during D4-7 Dithionite

indicate that all the available $\mathrm{Fe}$ (III) up to the radial distance of the well has been reduced to $\mathrm{Fe}(\mathrm{II})$. The duration of the reaction stage was approximately seven half-lives; therefore, injection/withdrawal test dithionite concentrations would be lowered to less than $1 \%$ of the concentrations at the beginning of the reaction stage if reducible Fe(III) were still present.

The higher concentrations injected into the upper portion of the aquifer, along with the density of the sodium dithionite solution $(\sim 1.06 \mathrm{~g} / \mathrm{mL})$, caused the reagent plume to sink during the reaction stage. This was evident in the measurements from the multilevel monitoring wells (see D4-2 and D4-3 results in Appendix E). Once the injection pump was turned off at the end of the injection stage, fluid density gradients caused the higher-concentration solutions in the upper portion of the aquifer to sink rapidly to the lower portion of the aquifer. This effect helped to increase the amount of dithionite reaching the lower portion of the aquifer and create a more uniform treatment zone.

\subsubsection{Withdrawal Stage}

The duration of the withdrawal stage for the D4-7 dithionite test was eight days at an extraction rate of $20 \mathrm{gpm}$. The total volume of water withdrawn was 154,500 gallons, representing 4.1 injection-volumes. The water was stored in frac tanks at the site. Samples were collected from the tanks and analyzed to ensure suitability for disposal at the ETF in the 200 Areas of the Hanford Site. Results of these analyses are given in Table 5.2. The water was approved for disposal at the ETF and trucked to the facility for treatment and disposal.

A mass balance for the injection/withdrawal test was calculated to estimate the percent recovery of the injected chemicals from the withdrawal stage. The estimate was based on the total mass of sulfur species (sulfate, sulfite, and thiosulfate) measured in both the injection and withdrawal 
Table 5.2. ISRM Groundwater Sample Analyses

\begin{tabular}{|c|c|c|c|c|c|c|c|c|c|c|c|c|c|c|c|}
\hline Sample ID & $\mathrm{pH}$ & $\begin{array}{c}\text { Density } \\
\text { (g/ml) }\end{array}$ & $\begin{array}{l}\text { TDS } \\
(\mathrm{g} / \mathrm{L})\end{array}$ & $\begin{array}{c}\text { TSS } \\
(\mathrm{mg} / \mathrm{L})\end{array}$ & $\begin{array}{c}\text { Total C } \\
(\mathrm{mg} / \mathrm{L})\end{array}$ & $\begin{array}{c}\text { TOC } \\
(\mathrm{mg} / \mathrm{L})\end{array}$ & $\begin{array}{c}\mathrm{F}^{-1} \\
(\mathrm{mg} / \mathrm{L})\end{array}$ & $\begin{array}{c}\mathrm{Cl}^{-1} \\
(\mathrm{mg} / \mathrm{L})\end{array}$ & $\begin{array}{l}\mathrm{NO}_{2}^{-1} \\
(\mathrm{mg} / \mathrm{L})\end{array}$ & $\begin{array}{l}\mathrm{NO}_{3}{ }^{-1} \\
(\mathrm{mg} / \mathrm{L})\end{array}$ & $\begin{array}{c}\mathrm{PO}_{4}^{-3} \\
(\mathrm{mg} / \mathrm{L})\end{array}$ & $\begin{array}{c}\mathrm{SO}_{4}^{-2} \\
(\mathrm{mg} / \mathrm{L})\end{array}$ & $\begin{array}{c}\mathrm{Br} r^{-1} \\
(\mathrm{mg} / \mathrm{L})\end{array}$ & $\begin{array}{c}\mathrm{SO}_{3}{ }^{2-} \\
(\mathrm{mg} / \mathrm{L})\end{array}$ & 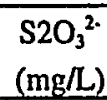 \\
\hline DT-1 & 9.45 & 1.0137 & 10.1 & 4 & 829 & 21 & 1.05 & 32 & $<2$ & 61 & $<3$ & 870 & 5.7 & 1780 & 9.8 \\
\hline DT-2 & 9.45 & 1.0159 & 14.9 & $<2$ & 1300 & 30 & 1.4 & 23 & $<2$ & 60 & $<3$ & 1470 & 6.9 & 2530 & 13 \\
\hline DT-3 & 9.13 & 1.0167 & 2.5 & (3) & 202 & 3.5 & 0.53 & 26 & $<2$ & 63 & $<3$ & 40 & 4.4 & 330 & 1.9 \\
\hline DT-4 & 9.45 & 1.0130 & 9.5 & (3) & $800^{\circ}$ & 24 & 1.06 & 25 & $<2$ & 63 & $<3$ & 850 & 5.7 & 1680 & 9.5 \\
\hline DT-5 & 9.45 & 1.0130 & 9.6 & 6 & 793 & 19 & 1.06 & 24 & $<2$ & 62 & $<3$ & 840 & 5.8 & 1650 & 9.4 \\
\hline DT-6 & 9.44 & 1.0130 & 9.4 & 5 & 788 & 21 & 1.04 & 24 & $<2$ & 62 & $<3$ & 1010 & 5.8 & 1610 & 8.9 \\
\hline DT-7 & 9.42 & 1.0135 & 9.1 & $<3$ & 756 & 20 & 1.03 & 24 & $<2$ & 61 & $<3$ & 1070 & .6 .0 & 1580 & 6.8 \\
\hline DT-8 & 9.45 & 1.0131 & 9.5 & $<3$ & 774 & 20 & 1.00 & 25 & $<2$ & 63 & $<3$ & 890 & 6.0 & 1690 & 8.9 \\
\hline VWA* & 9.40 & 1.0139 & 8.96 & $<4$ & 746 & 19.14 & 1.00 & 26 & $<2$ & 62 & $<3$ & 841 & 5.7 & 1546 & 8.2 \\
\hline
\end{tabular}

in

\begin{tabular}{|c|c|c|c|c|c|c|c|c|c|c|c|c|c|c|c|c|c|c|c|}
\hline Sample ID & $\begin{array}{c}\text { As } \\
(\mathrm{mg} / \mathrm{L})\end{array}$ & $\begin{array}{c}\mathrm{Ba} \\
(\mathrm{mg} / \mathrm{L})\end{array}$ & $\begin{array}{c}\mathrm{Ca} \\
(\mathrm{mg} / \mathrm{L})\end{array}$ & $\begin{array}{c}\mathrm{Cd} \\
(\mathrm{mg} / \mathrm{L}) \\
\end{array}$ & $\begin{array}{c}\mathrm{Cr} \\
(\mathrm{mg} / \mathrm{L})\end{array}$ & $\begin{array}{c}\mathrm{Cu} \\
(\mathrm{mg} / \mathrm{L})\end{array}$ & $\begin{array}{c}\mathrm{Fe} \\
(\mathrm{mg} / \mathrm{L})\end{array}$ & $\begin{array}{c}\mathrm{K} \\
(\mathrm{mg} / \mathrm{L}) \\
\end{array}$ & $\begin{array}{c}\mathrm{Mg} \\
(\mathrm{mg} / \mathrm{L})\end{array}$ & $\begin{array}{c}\mathrm{Mn} \\
(\mathrm{mg} / \mathrm{L})\end{array}$ & $\begin{array}{c}\mathrm{Na} \\
(\mathrm{mg} / \mathrm{L})\end{array}$ & $\begin{array}{c}\mathrm{Ni} \\
(\mathrm{mg} / \mathrm{L})\end{array}$ & $\begin{array}{c}P \\
(\mathrm{mg} / \mathrm{L}) \\
\end{array}$ & $\begin{array}{c}\mathrm{Pb} / \mathrm{L} \\
(\mathrm{mg} / \mathrm{L})\end{array}$ & $\begin{array}{c}S^{(2)} \\
(\mathrm{mg} / \mathrm{L}) \\
\end{array}$ & $\begin{array}{c}\mathrm{S}^{(\mathrm{b})} \\
(\mathrm{mg} / \mathrm{L})\end{array}$ & $\begin{array}{c}\mathrm{Se} \\
(\mathrm{mg} / \mathrm{L})\end{array}$ & $\begin{array}{c}\mathrm{Si} \\
(\mathrm{mg} / \mathrm{L})\end{array}$ & $\begin{array}{c}\mathrm{Zn} \\
(\mathrm{mg} / \mathrm{L})\end{array}$ \\
\hline DT-1 & $<0.3$ & 0.16 & 18 & $<0.1$ & 0.11 & $<0.2$ & 3.3 & 3200 & 38 & 0.12 . & 840 & 0.07 & 0.7 & $<.3$ & 960 & 1030 & $<.3$ & 3.4 & $<.03$ \\
\hline DT-2 & $<0.3$ & 0.57 & 16 & $<0.1$ & 0.16 & $<0.2$ & 3.9 & 4700 & 51 & 0.11 & 1200 & 0.08 & 1.2 & $<.3$ & 1400 & & $<.3$ & 3.4 & $<.03$ \\
\hline DT-3 & $<0.3$ & 0.08 & 19 & $<0.1$ & 0.04 & $<0.05$ & 0.11 & 1780 & 20 & 0.12 & 220 & 0.05 & 1.3 & $<.06$ & 280 & & $<.06$ & 3.7 & $<.006$ \\
\hline DT-4 & $<0.3$ & 0.17 & 18 & $<0.1$ & $<0.1$ & $<0.2$ & 2.5 & 3200 & 38 & 0.11 & 780 & 0.07 & 0.9 & $<.3$ & 900 & & $<.3$ & 3.4 & $<.03$ \\
\hline DT-5 & $<0.3$ & 0.19 & 18 & $<0.1$ & $<0.1$ & $<0.2$ & 2.5 & 2700 & 38 & 0.11 & 660 & 0.07 & 1 & $<.3$ & 930 & 960 & $<.3$ & 3.3 & $<.03$ \\
\hline DT-6 & $<0.3$ & 0.18 & 18 & $<0.1$ & $<0.1$ & $<0.2$ & 2.4 & 2700 & 39 & 0.11 & 670 & 0.06 & 0.9 & $<.3$ & 980 & & $<.3$ & 3.1 & $<.03$ \\
\hline DT-7 & $<0.3$ & 0.18 & 19 & $<0.1$ & $<0.1$ & $<0.2$ & 2.2 & 2900 & $\cdot 40$ & 0.11 & 770 & 0.06 & 0.8 & $<.3$ & 910 & & $<.3$ & 3.1 & $<.03$ \\
\hline DT-8 & $<0.3$ & 0.19 & 19 & $<0.1$ & $<0.1$ & $<0.2$ & 2.5 & $\begin{array}{r}3200 \\
\end{array}$ & 40 & 0.11 & 770 & 0.06 & 0.8 & $<.3$ & 950 & & $<3$ & 3.1 & $<.03$ \\
\hline VWA* & $<0.3$ & 0.19 & 18.26 & $<0.1$ & 0.10 & $<0.18$ & 2.3 & 2939 & 37.15 & 0.11 & 708 & 0.06 & 0.9 & $<.0 .27$ & 882 & 995 & $<0.27$ & 3.3 & $<0.03$ \\
\hline
\end{tabular}

* Volume Weighted Average

(a) $\mathrm{S}$ analysis was performed on unpreserved samples treated with $\mathrm{NH}_{4} \mathrm{OH}+\mathrm{H}_{2} \mathrm{O}_{2}$

(b) $\mathrm{S}$ analysis was performed on glycerine preserved samples treated with $\mathrm{NH}_{4} \mathrm{OH}+\mathrm{H}_{2} \mathrm{O}_{2}$ 
stages from samples collected periodically throughout those stages. The mass balance calculations resulted in an estimate from 62 to $65 \%$, which was significantly less than the $89 \%$ recovery obtained from the 100-H Area ISRM test in 1995 (Fruchter et al. 1997). Although the recovery from the D4-7 test was less than the 100-H Area test, the residual chemicals in the aquifer at the end of the tests were similar. Potential factors influencing the lower recovery at the 100-D Area ISRM site are

1) greater extent of the injection mound due to the lower hydraulic conductivity of the aquifer, causing reagent to be trapped in the vadose zone and difficult to recover

2) lower groundwater velocities in the lower portion of the aquifer inhibit the recovery of the reagent that sunk into the lower portion of the aquifer during the reaction stage due to density effects.

The design of the subsequent dithionite injection/withdrawal tests was modified to help improve the reagent recovery during the withdrawal stage (as discussed in the following section).

\subsection{Additional Dithionite Injection/Withdrawal Tests}

The modifications to the remaining four dithionite injection/withdrawal tests for completion of the emplacement of the permeable treatment zone involved smaller amounts of chemical used for injection, decreasing reagent concentrations during the injection stage, and withdrawal water disposal.

Analysis of the D4-7 test results, based on the concentrations of dithionite measured in the monitoring wells during the test, indicated that lower concentrations of dithionite could be used based on the amount of available Fe(III) in the aquifer sediments. The mass of chemicals used for the remaining two main dithionite/injection withdrawal tests (D4-12 and D4-10) were each 50\% of the mass used in the D4-7 test. Lower dithionite concentrations and volumes were also used for the two overlapping injection/withdrawal wells due to the smaller radius of influence of these wells. The mass of chemicals used for each of these overlapping wells was $60 \%$ of the mass used for the D4-12 and D4-10 tests (or 30\% of the D4-7 Test). The reductions in concentrations resulted in lower costs and minimized waste. The lower injection concentrations should also result in lower concentrations of residual chemicals in the aquifer.

Dithionite concentrations for the D4-12 and D4-10 tests were decreased during the injection because the greatest concentrations are needed at the front of the plume where dispersion effects, reaction time, and amount of $\mathrm{Fe}(\mathrm{III})$ along the pathline is the greatest. Table 5.1 shows the stepped concentrations used for these tests. Toward the end of the injection stage of these tests the reagent injection was ended, and groundwater containing no reagent was injected into the aquifer. This fresh-water push was used to help flush out reagent in the injection mound and enhance recovery during the withdrawal stage because most of the available Fe(III) surrounding the injection/withdrawal well was reduced during the earlier portion of the injection stage (and no additional reagent would be required). The estimated recovery during the withdrawal stage of the D4-12 injection was $72 \%+/-10 \%$.

The final modification to the injection/withdrawal tests involved disposing of the withdrawal water from the tests. For the remaining four dithionite injection/withdrawal tests, only the first 
injection-volume of withdrawn water required shipping, treatment, and disposal. The purge water modutanks were used for disposal of this water instead of the ETF. The remaining portion of the withdrawal water was purged to the ground to the west of the site, upgradient from well D4-13, through a 500-ft-long drip irrigation system. Vadose zone modeling analysis of the irrigation system showed that the sulfate concentrations in the aquifer below the surface discharge would be below $250 \mathrm{mg} / \mathrm{L}$. The groundwater sampling of the D4-13 well was increased to a quarterly interval to assess/verify the impacts of the purge water on the water quality. 


\subsection{Preliminary Performance Results}

\subsection{Groundwater Quality}

Groundwater monitoring was conducted at the site on a monthly to bimonthly basis during FY 1998. Results from the most recent sampling event (September 3, 1998) are shown in Tables 6.1 and 6.2. Average values and ranges of selected parameters for this sampling event are given for wells within the treatment zone in Table 6.3 and for the downgradient wells in Table 6.4. Hexavalent chromium results are shown in plan and cross-section views in Figures 6.1 and 6.2. Dissolved oxygen concentrations are shown in Figure 6.3. These analyses are discussed below and compared,with baseline data collected prior to any dithionite injection/withdrawal tests (see Section 3).

Concentrations of $\mathrm{Cr}^{6+}$ measured in the wells influenced by dithionite during the emplacement process were all below the detection limits of the field analysis equipment (Hach DR-2000) of $0.007 \mathrm{mg} / \mathrm{L}$ (see Figures 6.1 and 6.2). Average baseline $\mathrm{Cr}^{6+}$ concentrations measured for all the wells in the last baseline round of sampling (September 1997) were $1.0 \mathrm{mg} / \mathrm{L}$ (compare Tables 6.3 and 3.3).

Although concentrations of chromate and dissolved oxygen are significantly different from baseline values in the downgradient wells, the current results from the downgradient wells are still preliminary and cannot be used to assess the final performance of the ISRM technology. Sufficient time has not elapsed since the last emplacement (mid-July) for the site hydrology to return to ambient conditions from the injections and pumping. Once the natural conditions return, an additional time is required ( $\mathrm{a}$ few months) for groundwater to travel through the barrier to reach all the downgradient wells. In addition, based on groundwater flow directions from water tables measurements during the previous year, well D4-4 is on the eastern downgradient edge (or outside) of the treatment zone and may not be useful for assessing the downgradient effects of the treatment zone.

Differences between baseline groundwater parameters within the treatment zone, in addition to the hexavalent chromium concentrations discussed above, include dissolved oxygen, $\mathrm{pH}$, electrical conductivity, sulfate, and $\mathrm{Mn}$. Dissolved oxygen reacts with the $\mathrm{Fe}(\mathrm{II})$ within the treatment zone. The oxidizing capacity of dissolved oxygen is greater than the hexavalent chromium and mainly determines the longevity of the treatment zone. The $\mathrm{pH}$ within the treatment zone is above baseline values as shown in Tables 3.3 and 6.3. The pH is elevated within the treatment zone from residual potassium carbonate/ potassium bicarbonate $\mathrm{pH}$ buffer added to the reagent to enhance dithionite stability. The electrical conductivity is elevated in the reduced zone above baseline values due to the residual chemicals left in the aquifer from unrecovered reagents (Na, $\mathrm{K}$, carbonate/ bicarbonate, and sulfate). Unreacted dithionite and the sulfate/thiosulfate reactions products ultimately oxidize to sulfate.

Electrical conductivity and sulfate analysis indicate that the vadose zone is the source of the elevated levels due to reagent trapped in the injection mound during the emplacement. The highest concentrations were seen in the uppermost Westbay well (D4-16 zone 1) and Well D4-1 


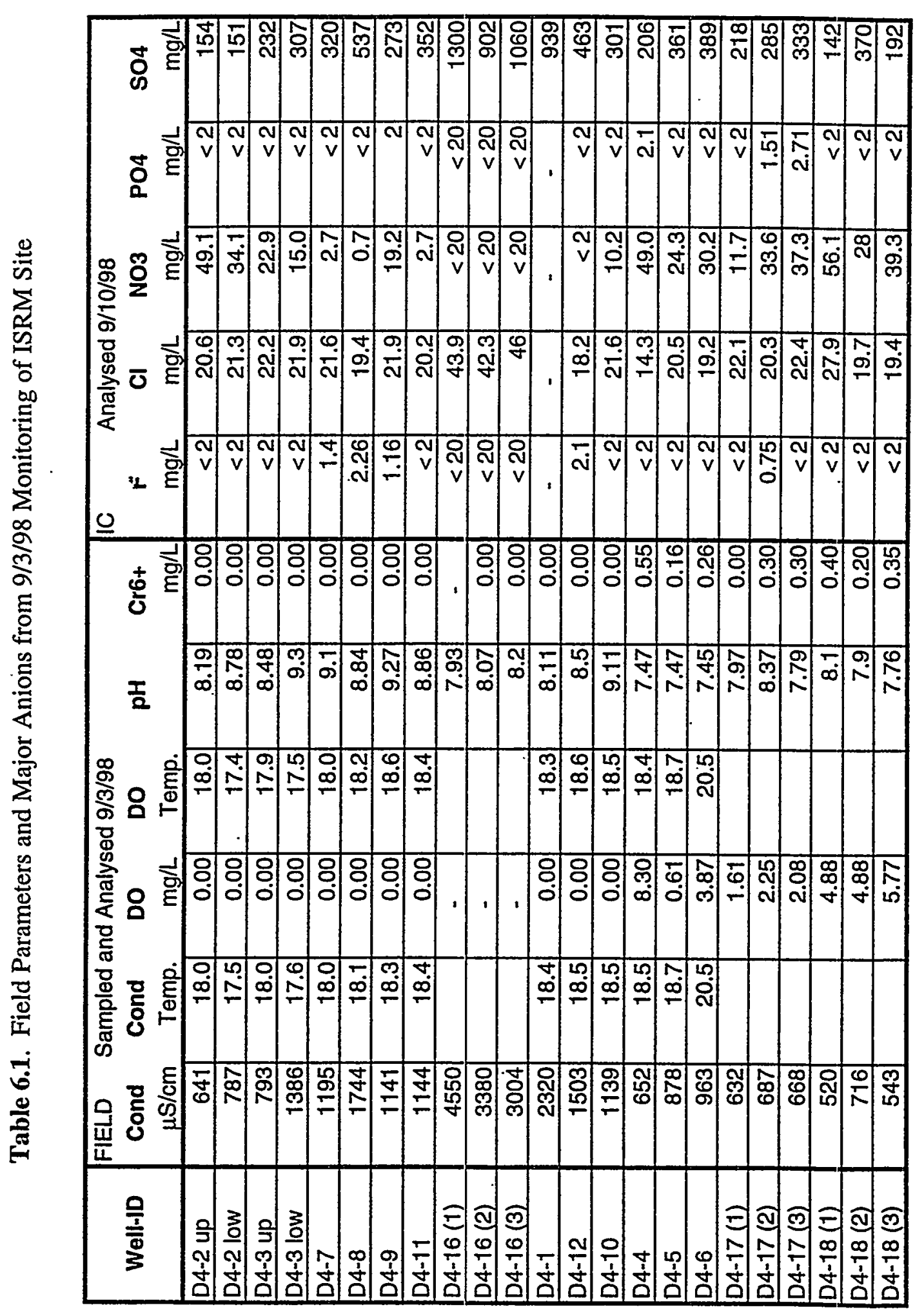




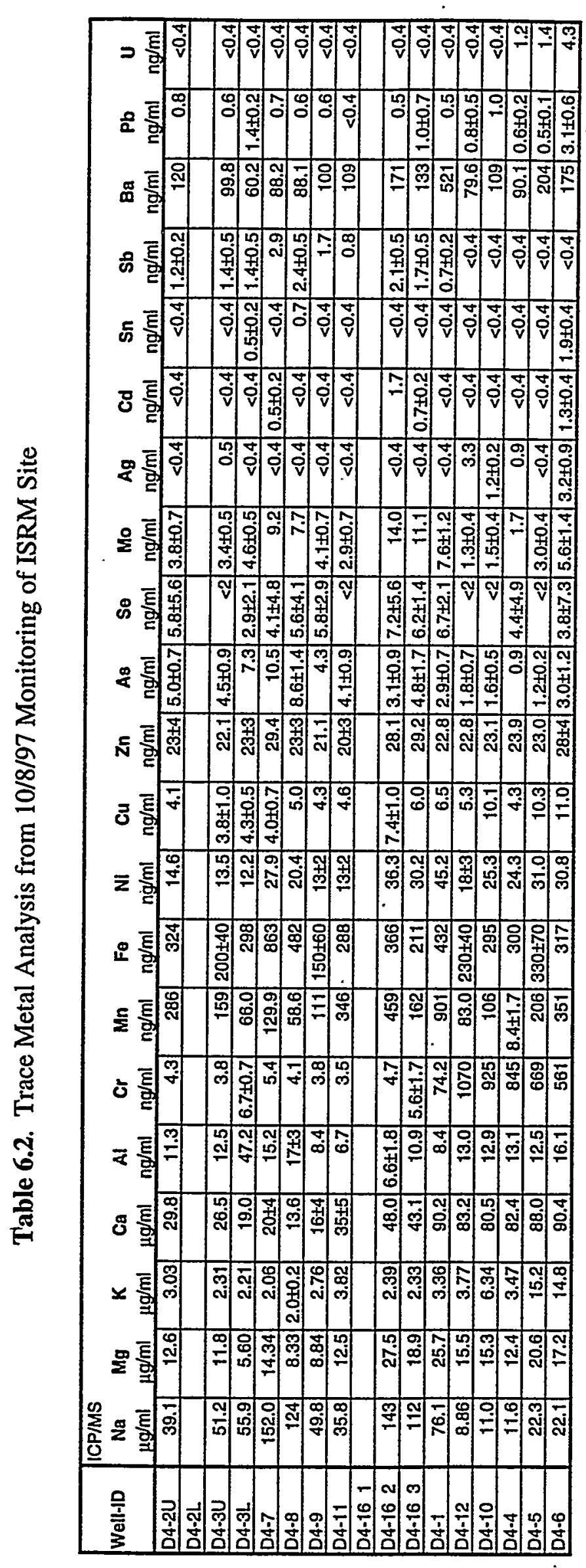


Table 6.3. Groundwater Measurement Summary Within the Treatment Zone (9/3/98)

\begin{tabular}{|l|c|c|c|}
\hline \multicolumn{1}{|c|}{ Parameter } & Units & Range & Average \\
\hline $\mathrm{pH}$ & & 7.93 to 9.30 & 8.62 \\
\hline Electrical Conductivity & $\mu \mathrm{S} / \mathrm{cm}$ & 641 to 4,550 & 1766 \\
\hline Dissolved Oxygen & $\mathrm{mg} / \mathrm{L}$ & 0 & 0 \\
\hline Sulfate & $\mathrm{mg} / \mathrm{L}$ & 151 to 1300 & 521 \\
\hline Hexavalent Chromium & $\mathrm{mg} / \mathrm{L}$ & 0 & 0 \\
\hline
\end{tabular}

Table 6.4. Groundwater Measurement Summary Downgradient of the Treatment Zone (9/3/98)

\begin{tabular}{|l|c|c|c|}
\hline \multicolumn{1}{|c|}{ Parameter } & Units & Range & Average \\
\hline $\mathrm{pH}$ & & 7.45 to 8.37 & 7.81 \\
\hline Electrical Conductivity & $\mu \mathrm{S} / \mathrm{cm}$ & 520 to 963 & 695 \\
\hline Dissolved Oxygen & $\mathrm{mg} / \mathrm{L}$ & 0.61 to 8.3 & 8.3 \\
\hline Sulfate & $\mathrm{mg} / \mathrm{L}$ & 142 to 389 & 277 \\
\hline Hexavalent Chromium & $\mathrm{mg} / \mathrm{L}$ & 0 to 0.55 & 0.28 \\
\hline
\end{tabular}

on the downgradient portion of the treatment zone. Higher concentrations on the downgradient side of the treatment zone and in the upper portions of the aquifer suggest concentrations increasing along the flow path through the treatment zone from recharge from the vadose zone. Concentrations of the residuals (e.g., sulfate) are not expected to persist for a long time after emplacement.

Within the treatment zone, manganese concentrations were elevated above baseline conditions due to the enhanced solubility of naturally occurring manganese oxides within the sediments under reducing conditions. Although these concentrations are elevated in the treatment zone, manganese should not be mobile beyond the treatment zone due to its high retardation factor and reprecipitation once it contacts downgradient oxidizing sediments.

The trace metal data shown in Table 6.2 are from the post- D4-7 dithionite injection/withdrawal test in October 1997. More recent trace metal analysis will be available in early FY-99.

\subsection{Columbia River Pore Water Sampling Tubes}

The most recent results from the 100-D Area ISRM. Columbia River Pore Water Sampling Tubes are listed in Table 6.5. The complete set of results from FY 1998 is in Appendix C. ISRM Pore Water Sampling Tubes (Redox-0103.3, 0106.0, 0203.0, 0206.0, 0303.3, 0304.6, 0403.0, and 0406.0) were installed in November and December 1997, after the D4-7 dithionite injection/ withdrawal test. Four pairs of sampling tubes were installed at four locations along the river downgradient from the ISRM site with two sampling depths each (the last two digits of the $\mathrm{ID}$ are the sampling depths). The TD-39 sampling tubes were installed prior to the ISRM emplacement (Peterson et al. 1998). 


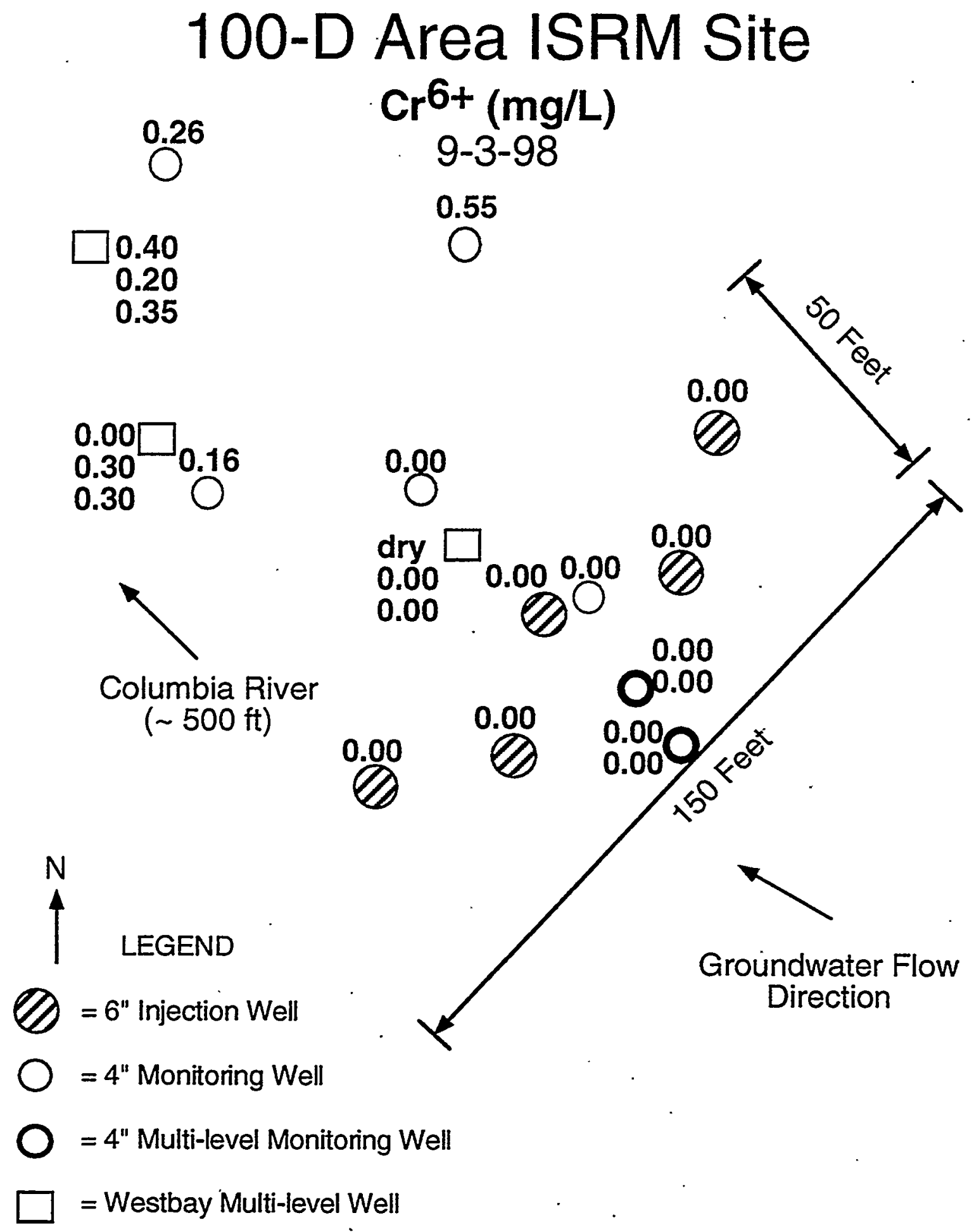

Figure 6.1. Post-Emplacement Hexavalent Chromium Concentrations at the 100-D Area ISRM Site 


\section{0-D Area In Situ Redox Manipulation \\ $\mathrm{Cr6}+(\mathrm{mg} / \mathrm{L})$ 9/3/98 \\ SW - NE TRANSECT (Cross Gradient)}

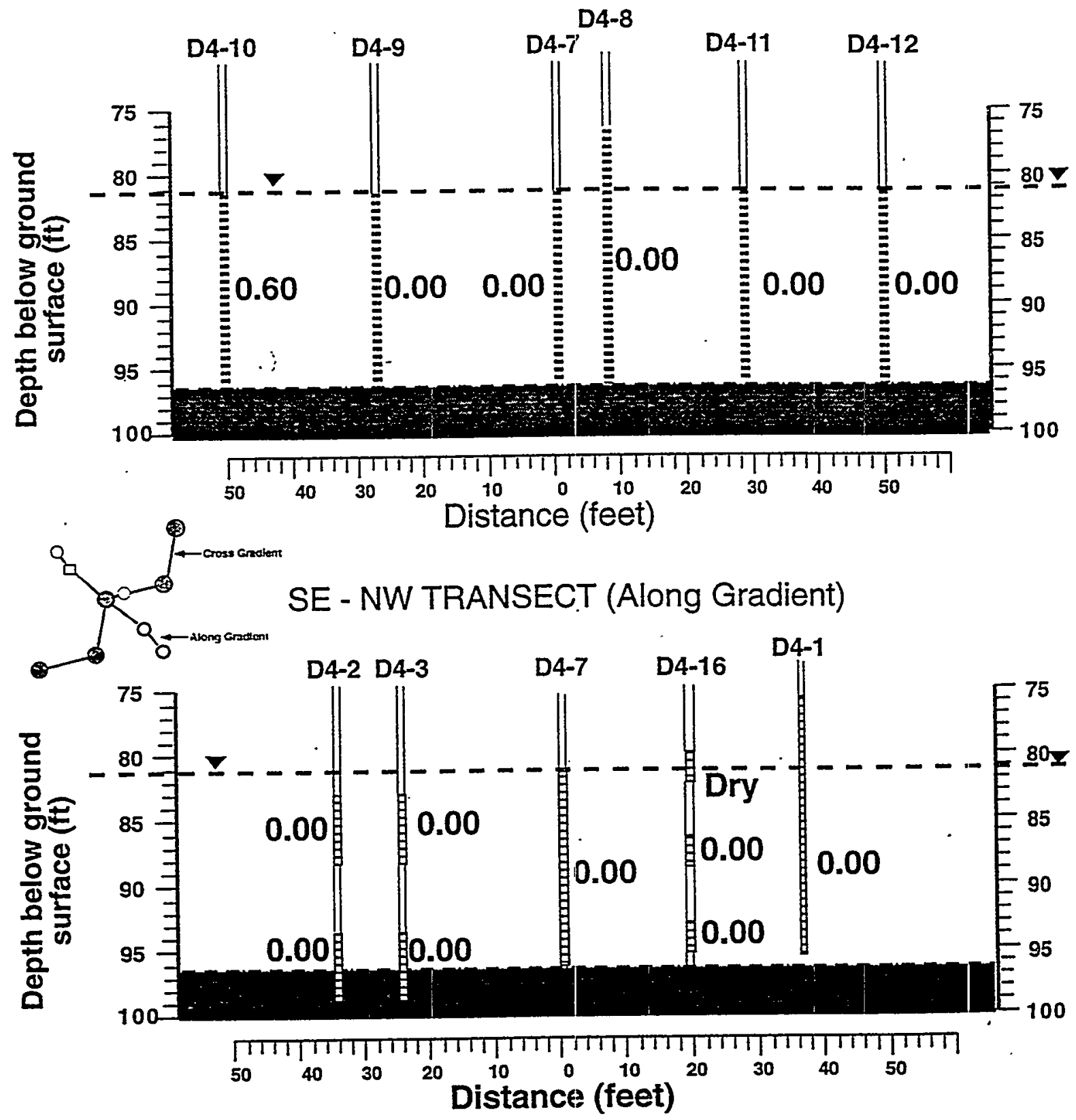

Figure 6.2. Cross-Section of Post-Emplacement Hexavalent Chromium at the 100-D Area ISRM Site 


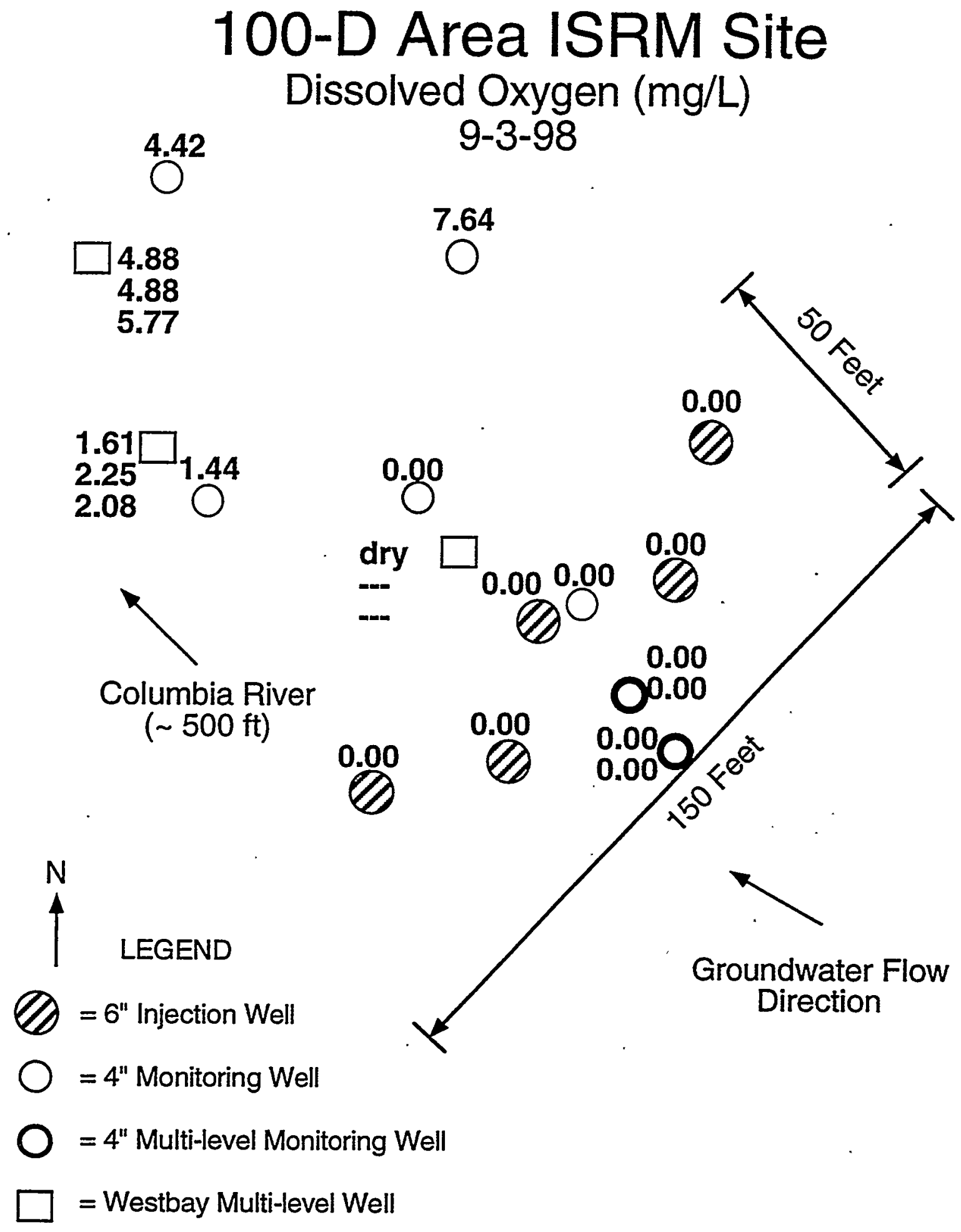

Figure 6.3. Post-Emplacement Dissolved Oxygen Concentrations at the 100-D Area ISRM Site 
Table 6.5. Porewater Sampling Summary

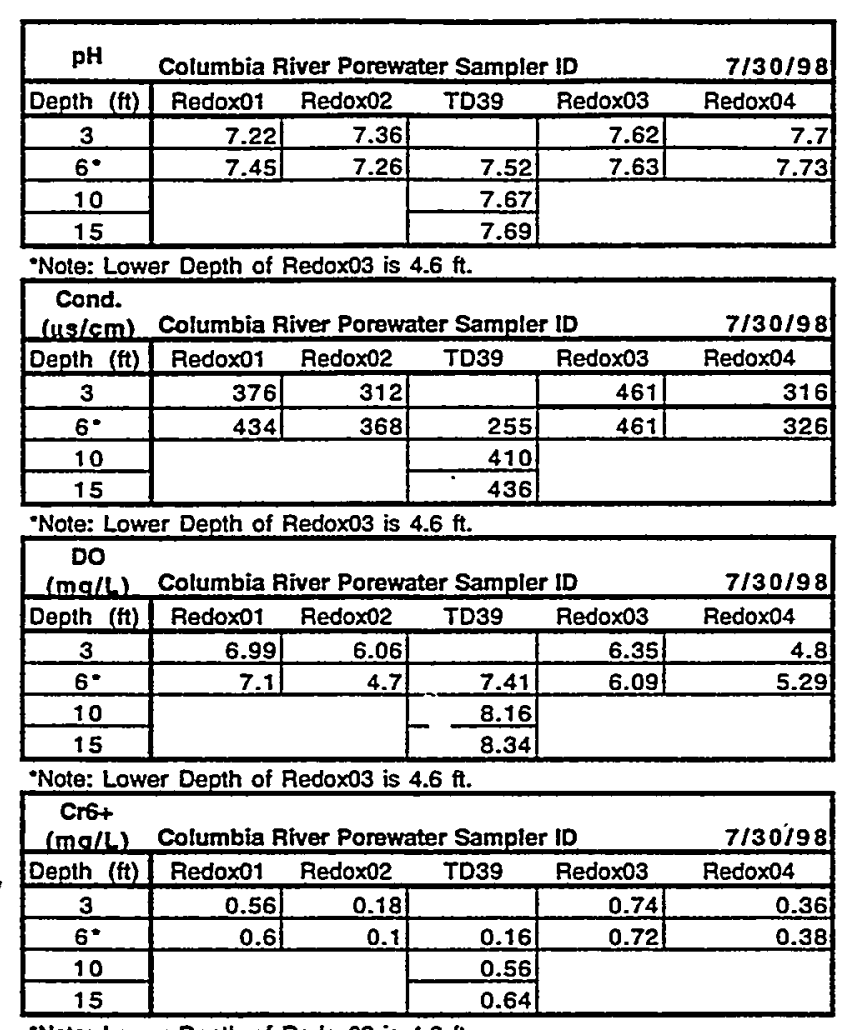

"Note: Lower Depth of Redox03 is $4.6 \mathrm{ft}$.

\begin{tabular}{|c|c|c|c|c|c|}
\hline$\underset{\mathrm{Snnml}}{\mathrm{SO}_{4}{ }^{2-}}$ & Columbia F & iver Porew & r Sample & 10 & $7 / 30 / 98$ \\
\hline Depth (fi) & Redox01 & Redox02 & TD39 & Redox03 & Redox04 \\
\hline 3 & 59.1 & 42.2 & & 72.7 & 41.7 \\
\hline 6 & 66.1 & 52.7 & 28.2 & 72.2 & \\
\hline 10 & & & 63 & & \\
\hline 15 & & & 68.2 & & \\
\hline
\end{tabular}

\begin{tabular}{|c|c|c|c|c|c|}
\hline $\mathrm{Cl}^{-}$(ppm) & Columbia F & iver Porew & I Sample & 10 & $7 / 30 / 98$ \\
\hline Depth (ft) & Redox01 & Redox02 & TD39 & Redox03 & Redox04 \\
\hline 3 & 11.4 & 7.68 & & 15.3 & 9.73 \\
\hline 6 & 15.4 & 10.3 & 4.1 & 14.9 & \\
\hline 10 & & & 12.3 & & \\
\hline 15 & & & 14.5 & & \\
\hline
\end{tabular}

\begin{tabular}{|c|c|c|c|c|c|}
\hline $\mathrm{NO}_{3}^{-}$ & Columbia F & iver Porew & Sample & ID & $7 / 30 / 98$ \\
\hline Depth $(\mathrm{ft})$ & Redox01 & Redox02 & TD39 & Redox03 & Redox04 \\
\hline 3 & 27 & 19.2 & & 35.4 & 19.4 \\
\hline 6 & 36.2 & 21.9 & 11.3 & 34.8 & \\
\hline 10 & & & 30.7 & & \\
\hline 15 & & & 56.3 & & \\
\hline
\end{tabular}

\begin{tabular}{|c|r|r|r|r|r|}
\hline $\begin{array}{c}\text { PO }^{2} \\
\text { lonml }\end{array}$ & \multicolumn{6}{c|}{ Columbia River Porewater Sampler tD } & 7/30/98 \\
\hline Depth (ft) & Redox01 & Redox02 & \multicolumn{1}{c|}{ T039 } & Redox03 & Redox04 \\
\hline 3 & $<0.2$ & 0.94 & & 0.62 & $<0.2$ \\
\hline 6 & 1.02 & 0.36 & 1.4 & 1.3 & \\
\hline 10 & & & 0.46 & & \\
\hline 15 & & & $<0.2$ & & \\
\hline
\end{tabular}

\begin{tabular}{|c|r|r|r|r|r|}
\hline \multicolumn{7}{|c|}{ F' (ppm) } & Columbia Aiver Porewater Sampler ID & I/30/98 \\
\hline Depth (ft) & Redox01 & Redox02 & \multicolumn{1}{c|}{ T039 } & Redox03 & Redox04 \\
\hline 3 & 0.34 & 0.31 & & 0.37 & 0.31 \\
\hline 6 & 0.4 & 0.34 & 0.23 & 0.35 & \\
\hline 10 & & & 0.31 & & \\
\hline 15 & & & 0.43 & & \\
\hline
\end{tabular}

Water samples collected from the sampling tubes are a mixture of both river water and groundwater. The contribution of each source to the sample is related to the river stage and aquifer pressures at the time of sampling. Samples collected at the high river stage are dominated by river water. Because the river water and groundwater have distinct ranges of electrical conductivity (river water $\sim 150 \mathrm{microS} / \mathrm{cm}^{2}$ and groundwater $\sim 600 \mathrm{microS} / \mathrm{cm}^{2}$ ), the electrical conductivity can be used to distinguish the relative contribution of each (see mixing curves in Peterson et al. 1998; Hope and Peterson 1996). Hexavalent chromium has not been detected in the river water. It is important to consider the electrical conductivity of the samples when comparing hexavalent chromium concentrations.

With the exception of Redox02 ( 3 and $6 \mathrm{ft}$ depth), hexavalent chromium concentrations results from the ISRM Columbia River Pore Water Sampling tubes are similar to results shown in previous pore water sampling studies (Hope and Peterson 1996; Peterson et al. 1998) with the range in hexavalent chromium concentrations from 0.36 to $0.88 \mathrm{mg} / \mathrm{L}$ when the samples had relatively high electrical conductivity $(>300 \mathrm{microS} / \mathrm{cm})$. Redox03 consistently had the highest 
hexavalent chromium concentrations. Redox 02 samples consistently had anomalous, low hexavalent chromium concentrations, even when it had high electrical conductivity measurements indicating a significant contribution of groundwater.

In addition to hexavalent chromium and electrical conductivity, Table 6.5 and Appendix $\mathrm{C}$ also contain $\mathrm{pH}$ and dissolved oxygen measurements. Major anion analysis was also conducted for the some of the sampling rounds and the results are including in these tables.

\subsection{Estimated Barrier Longevity}

As discussed in Section 4, the average reducible Fe(III) content of the sediments in the aquifer at the 100-D Area ISRM site, as determined by bench-scale testing, was $31.8 \pm 5.6 \mu \mathrm{mol}$ reducible $\mathrm{Fe}(\mathrm{III})$ per gram of soil. Using this value and the average values for physical properties at the 100-D Area (14\% porosity and $2.3 \mathrm{~g} / \mathrm{cm}^{3}$ dry bulk density) results in a treatment capacity of 171 \pm 46 pore volumes for the contaminated groundwater at the site $(8 \mathrm{mg} / \mathrm{L}$ dissolved oxygen and 1 $\mathrm{mg} / \mathrm{L}$ hexavalent chromium). Assuming this average was attained for a 50- $\mathrm{ft}$ width at the 100-D Area site, the predicted longevity of the 100-D Area ISRM permeable treatment zone is $23 \pm 6$ years (using a $1 \mathrm{ft} /$ day groundwater velocity). This estimate also neglects other oxygen fluxes into the treatment zone, such as from the vadose zone or from upwelling from the lower aquifers.

Sediment samples collected from the core holes in the treatment zone are required to measure the reductive capacity achieved during emplacement and are planned for FY 1999. 


\subsection{Planned FY 1999 Activities}

Activities during FY 1999 at the 100-D Area site include continued aqueous monitoring, installing two new monitoring wells, drilling core holes for collecting sediment from the reduced zone, completing the reoxygenation studies, and writing the final treatability test report. Sampling of the wells and Columbia River substrate pore water samplers will be conducted on a frequency of every two months during FY 1999.

The additional monitoring wells will provide a new upgradient well and an additional downgradient well between D4-6 and the river. The new upgradient well is needed because the existing upgradient wells D4-3 and D4-2 were both influenced by dithionite during the injections. The additional downgradient well will provide aqueous samples closer to the river for the anoxic plume studies. The distance between our farthest downgradient well and the river is now $400 \mathrm{ft}$.

Core holes from within the reduced zone will provide sediment samples for conducting laboratory tests to determine the reductive capacity achieved during the dithionite injection/ withdrawals. These data will be used to estimate the longevity of the reduced zone. Current estimates of longevity are based on the potential reductive capacity of the sediment samples collected during the initial stages of drilling. A comparison of the maximum potential and the amount achieved will provide a measure of efficiency for the emplacement method.

The studies into the mechanisms for the attenuation of the anoxic plume that forms downgradient of the ISRM permeable treatment zone will also be completed in FY 1999. Experiments conducted in FY 1998 for this effort included a dissolved gas field tracer test to characterize entrapped air in the aquifer and intermediate-scale laboratory experiments on the mechanisms of air entrapment from water table fluctuations. These data will be analyzed, and a numerical model incorporating these and other mechanisms will be developed for predicting dissolved oxygen concentrations downgradient from the 100-D Area ISRM site. A treatability test report will be prepared to provide a final analysis and conclusions of this test. 


\subsection{References}

Connelly MP. 1997a. Plan for the Characterization and Remediation of the Chromium Plume West of the 100-D Reactor. BHI-00967 Rev 0, Bechtel Hanford Co., Richland, Washington.

Connelly MP. 1997b. Chromium Plume West of the 100-D/DR Reactors - Data Supplement. BHI-01132 Rev 0, Bechtel Hanford co., Richland, Washington.

Connelly MP, CR Cole, and MD Williams. 1997c. Bank Storage Modeling at the 100-N Area. CH2MHill Hanford, Richland, Washington.

Cummings MA. 1997. Cost Effectiveness of In Situ Redox Manipulation for Remediation of Chromium-Contaminated Groundwater. LA-UR-97-165, Los Alamos National Laboratory, Los Alamos, New Mexico.

Fruchter JS, JE Amonette, CR Cole, YA Gorby, MD Humphrey, JD Istok, FA Spane, JE Szecsody, SS Teel, VR Vermeul, MD Williams, and SB Yabusaki. 1996. In Situ Redox Manipulation Field Injection Test Report - Hanford 100H Area. PNNL-11372, Pacific Northwest National Laboratory, Richland, Washington.

Fruchter IS, MD Williams, VR Vermeul, CR Cole, and SS Teel. 1997. Treatability Test for In Situ Redox Manipulation in the 100-HR-3 Operable Unit, D-Area, Hanford Site, Washington. Pacific Northwest National Laboratory, Richland, Washington.

Fruchter JS, CR Cole, MD Williams, VR Vermeul, JE Amonette, JE Szecsody, JD Istok, and MD Humphrey. 1998. Creation Of A Subsurface Permeable Treatment Barrier Using In Situ Redox Manipulation. Submitted for publication in Groundwater Monitoring and Remediation.

Fruchter JS, JE Amonette, CR Cole, YA Gorby, MD Humphrey, JD Istok, FA Spane, JE Szecsody, SS Teel, VR Vermeul, MD Williams, and SB Yabusaki. 1996. In Situ Redox Manipulation Field Injection Test Report - Hanford 100 H Area. PNNL-11372, Pacific Northwest National Laboratory, Richland, Washington.

Hope SK and RE Peterson. 1996. Chromium in the River Substrate Pore Water and Adjacent Groundwater: 100-D/DR Area, Hanford Site, Washington. BHI-00778 Rev.0, Bechtel Hanford Co., Richland, Washington.

Lindsey KA and GK Jaeger. 1993. Geologic Setting of the 100-HR-3 Operable Unit, Hanford Site, South-Central Washington. WHC-SD-EN-TI-132 Rev. 0, Westinghouse Hanford Company, Richland, Washington.

Luttrell S, M Chamness, D Dauble, R Dirkes, and T Walters. 1995. Letter Report-100-HR-3, Groundwater and Riverbank Springs Information and Fall Chinook Spawning Habitat of the Hanford Reach, Columbia River. Pacific Northwest Laboratory. Richland, Washington 
Mueller RP and DR Geist. 1998. Evaluation of Fall Chinook Salmon Spawning Adjacent to the In-Situ Redox Manipulation Treatability Test Site, Hanford Nuclear Reservation, Washington. Letter Report, Pacific Northwest National Laboratory, Richland, Washington.

Peterson RE, JV Borghese, and DB Erb. 1998. Aquifer Sampling Tube Completion Report: 100 Area and Hanford Townsite Shoreline. BHI-01153 Rev. 0, Bechtel Hanford Co., Richland, Washington.

U.S. Department of Energy. 1995. Proposed Plan for Interim Remedial Measure at the 100HR-3 Operable Unit. DOE/RL-94-102, U.S. DOE Richland Operations, Richland, Washington.

Weeks DC. 1997. Borehole Summary Completion Report for the Chromium Plume West of the 100-D/DR Reactors. BHI-01101 Rev. 0, Bechtel Hlanford Co., Richland, Washington. 


\section{Appendix A}

\section{Well Summary Diagrams}




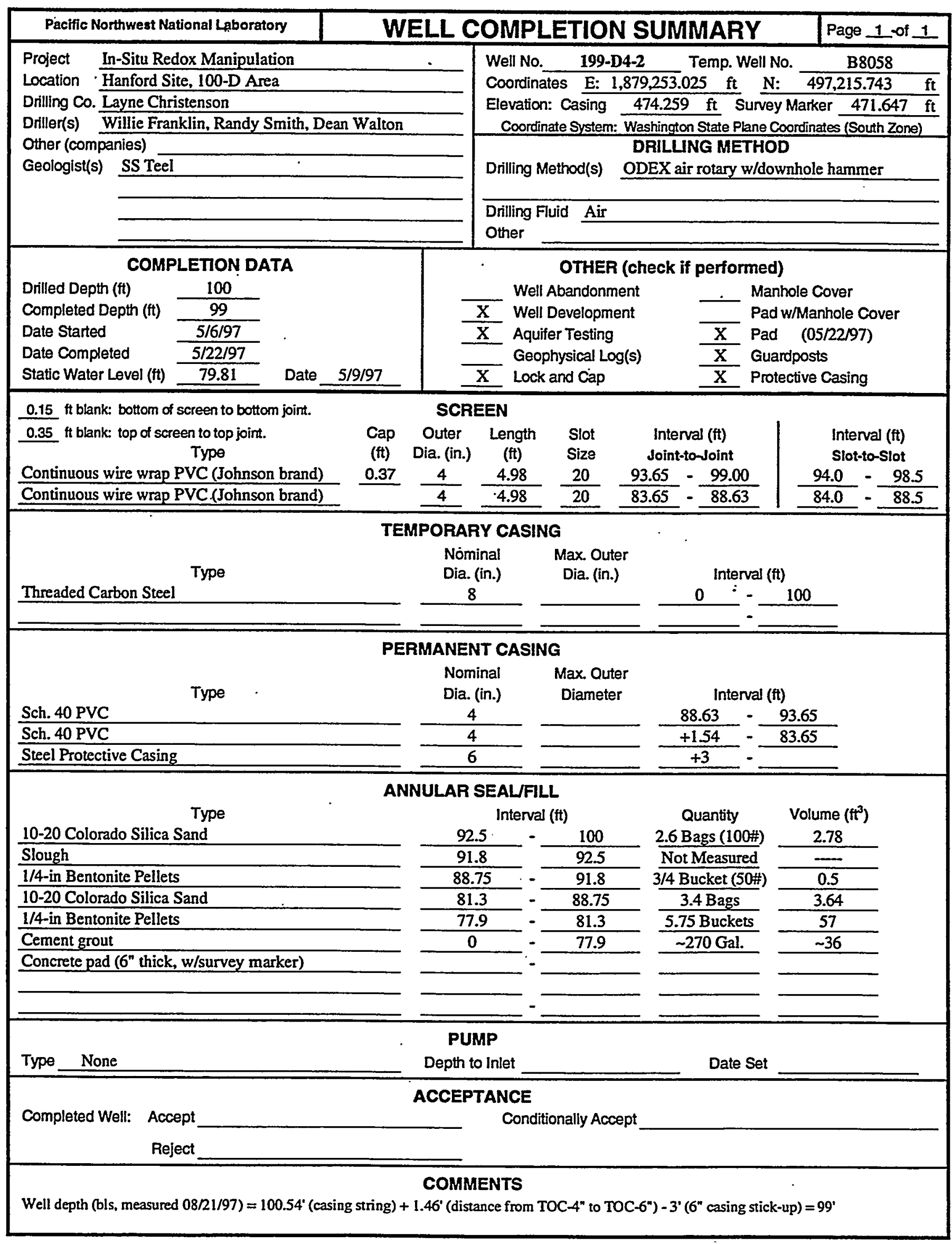

Reviewed by

Date

Depths are below land surface unless noted. 


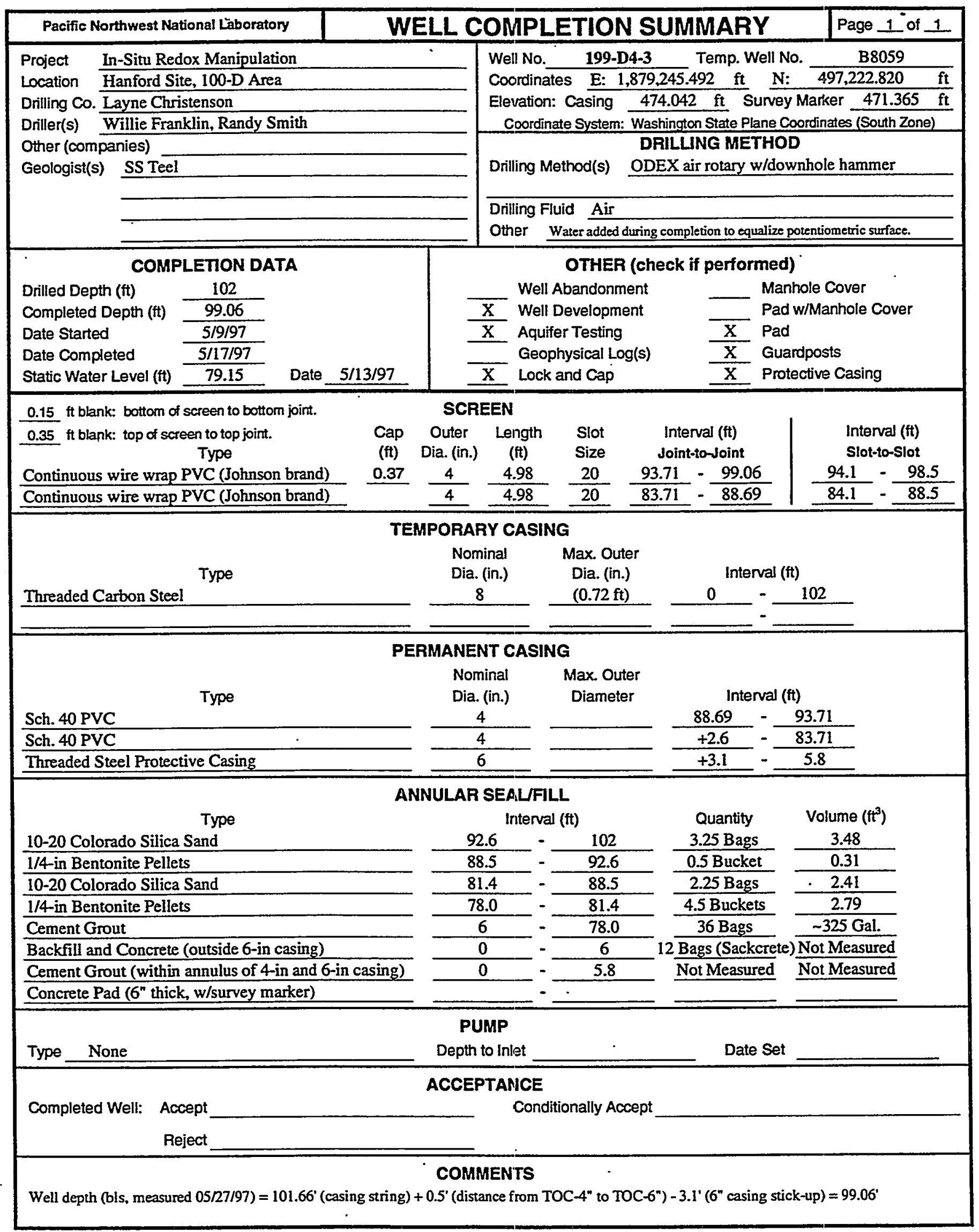

Reviewed by

Date

Depths are below land surface unless noted. 


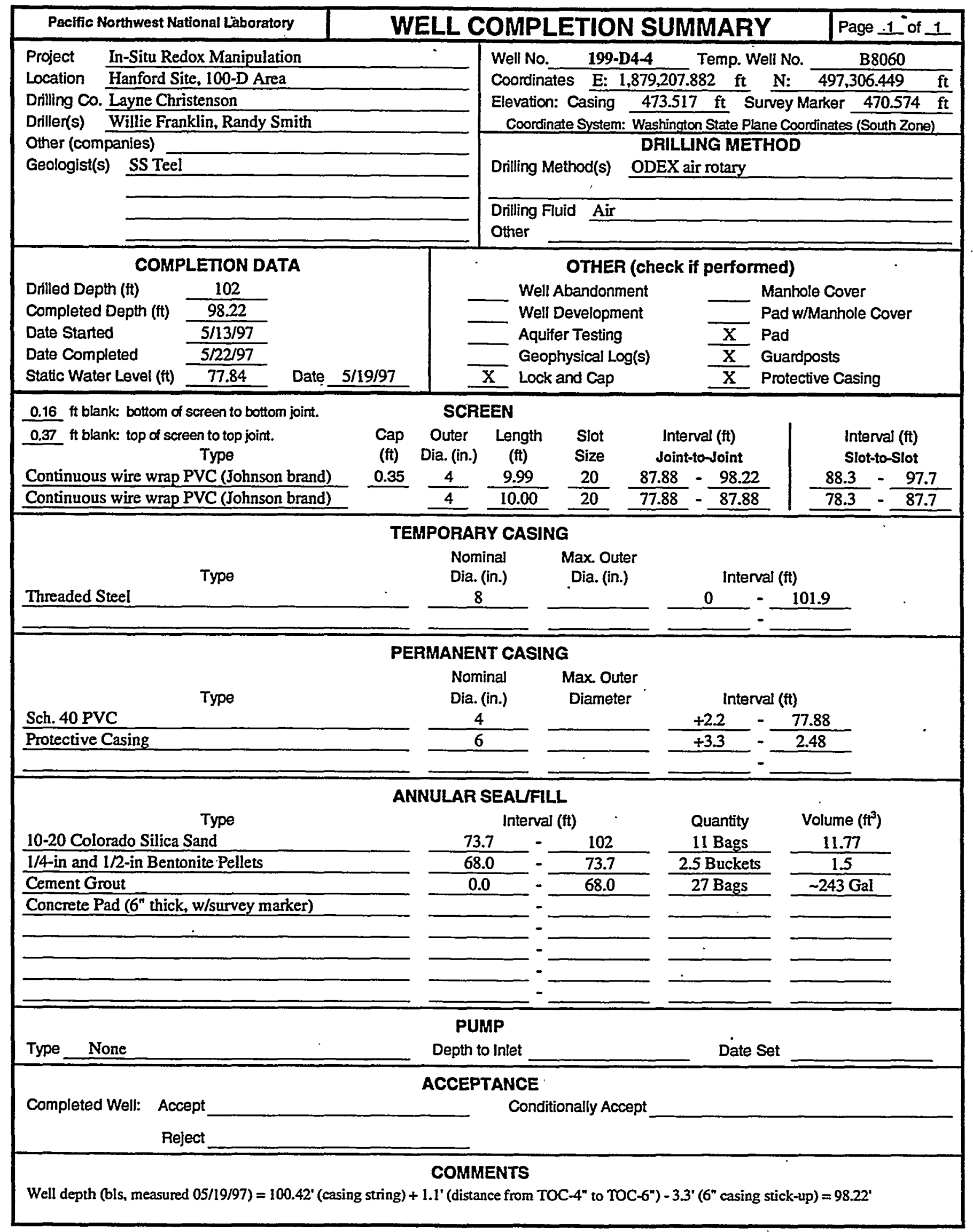




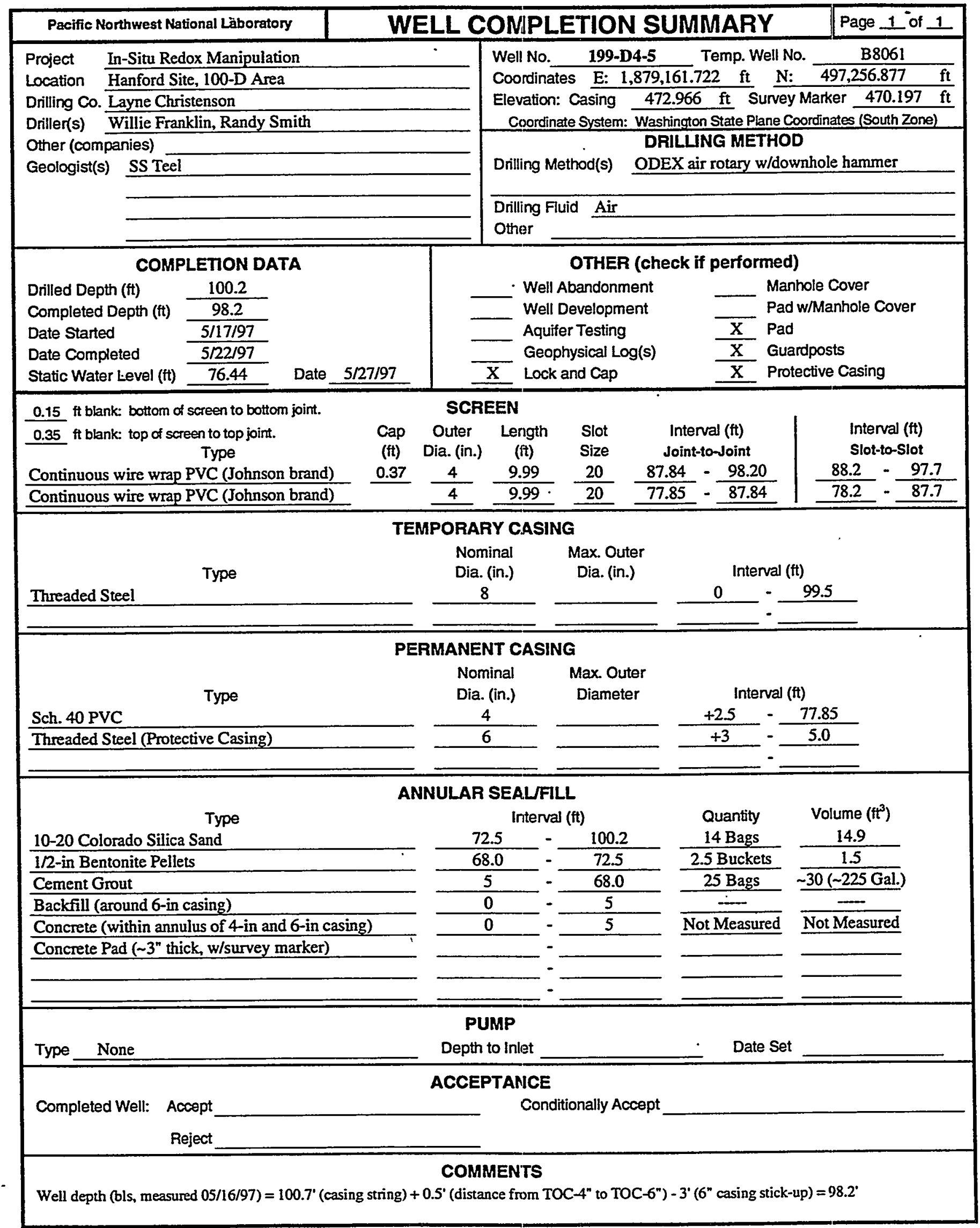

Reviewed by

Date

Depths are below land surface unless noted. 


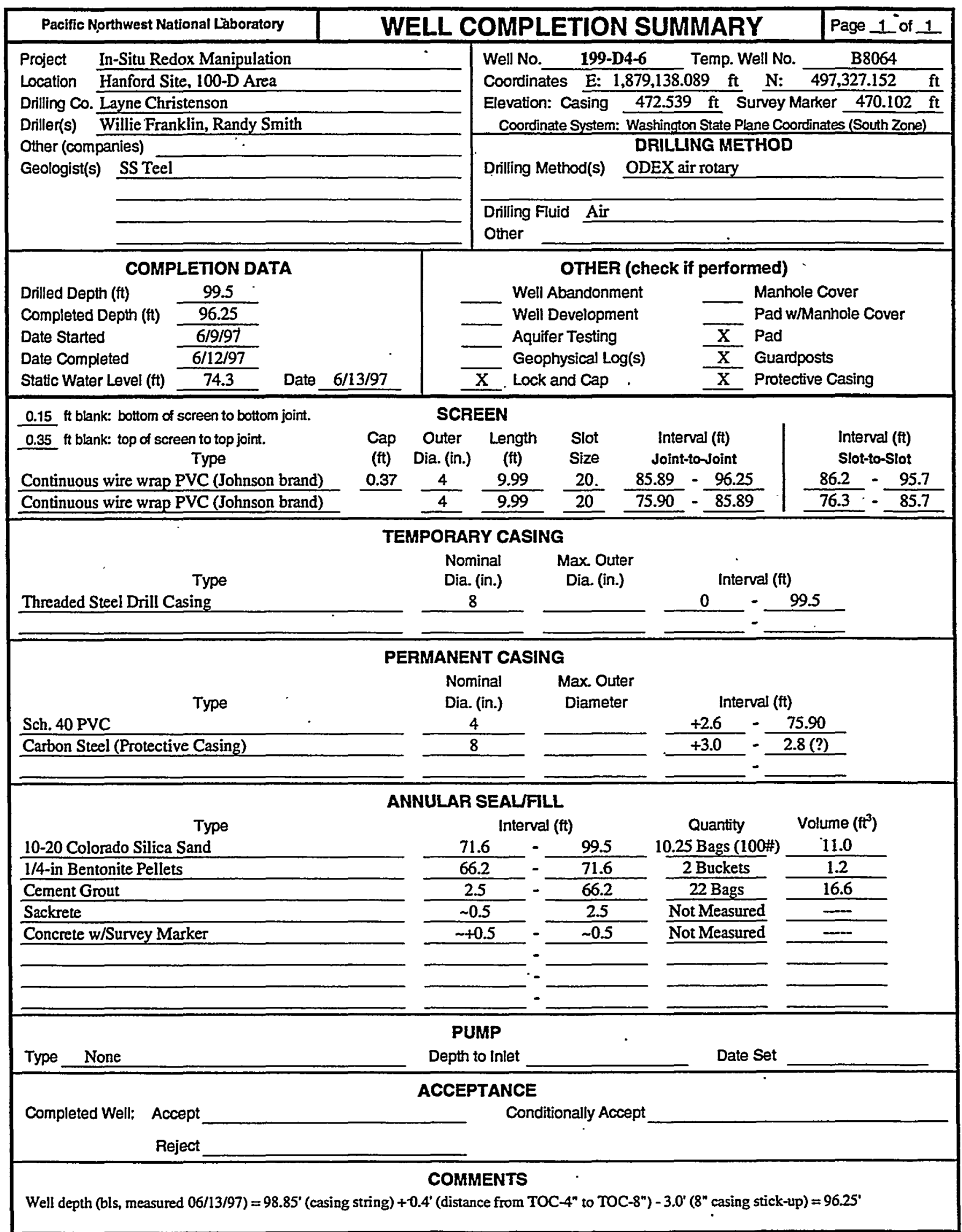

Reviewed by

Date

Depths are below land surface unless noted. 


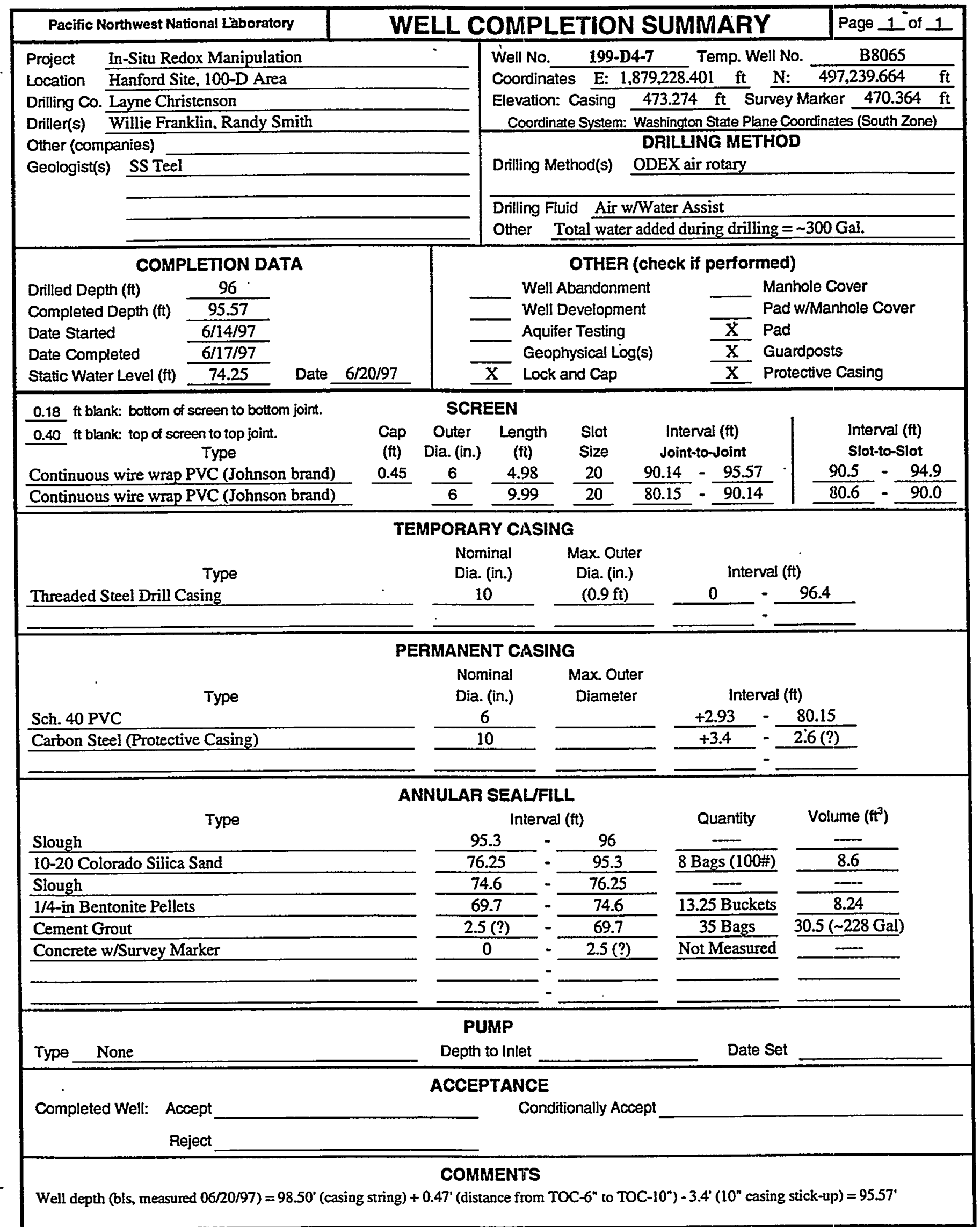

Reviewed by

Date

Depths are below land surface unless noted. 


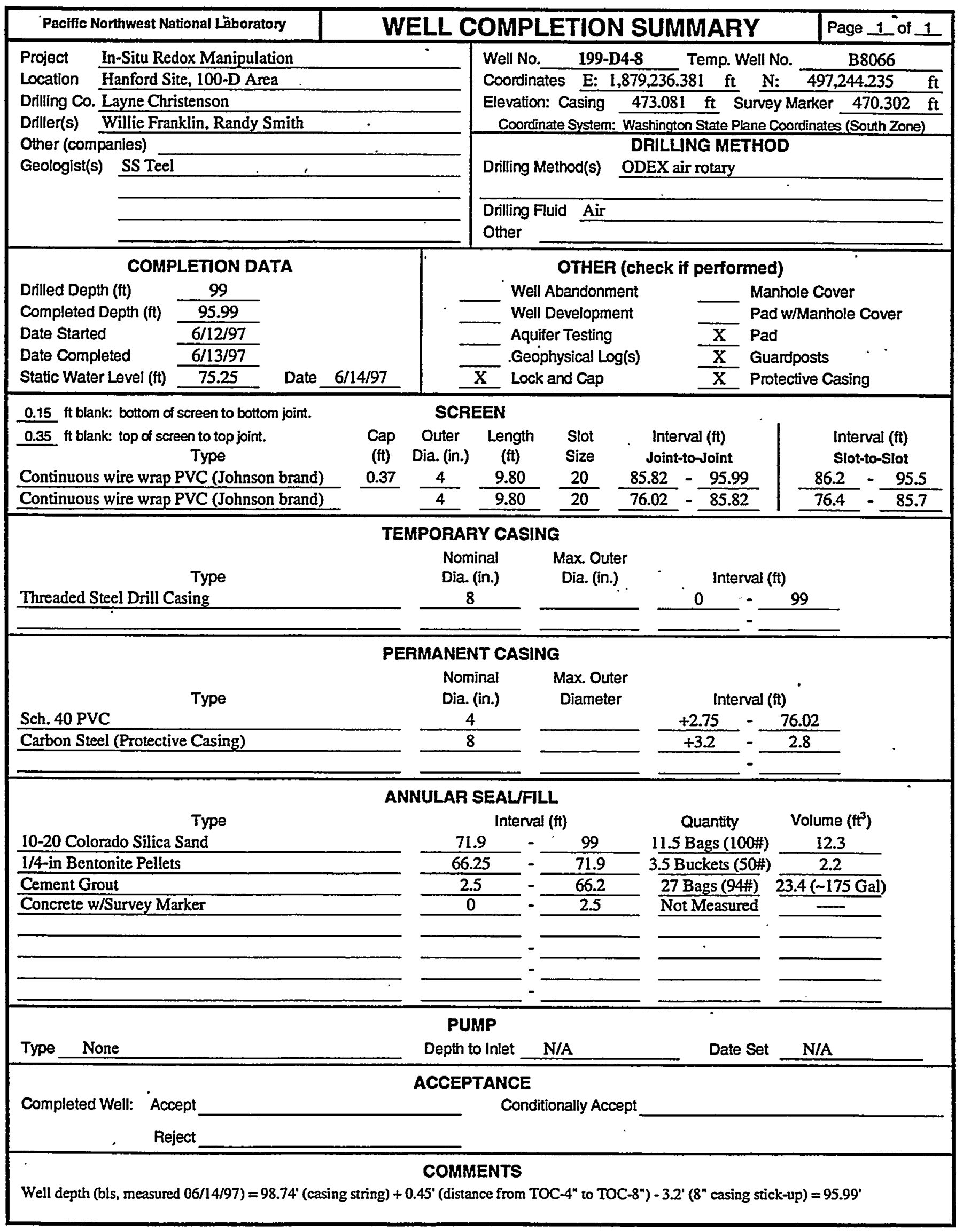

Reviewed by Date

Depths are below land surface unless noted. 


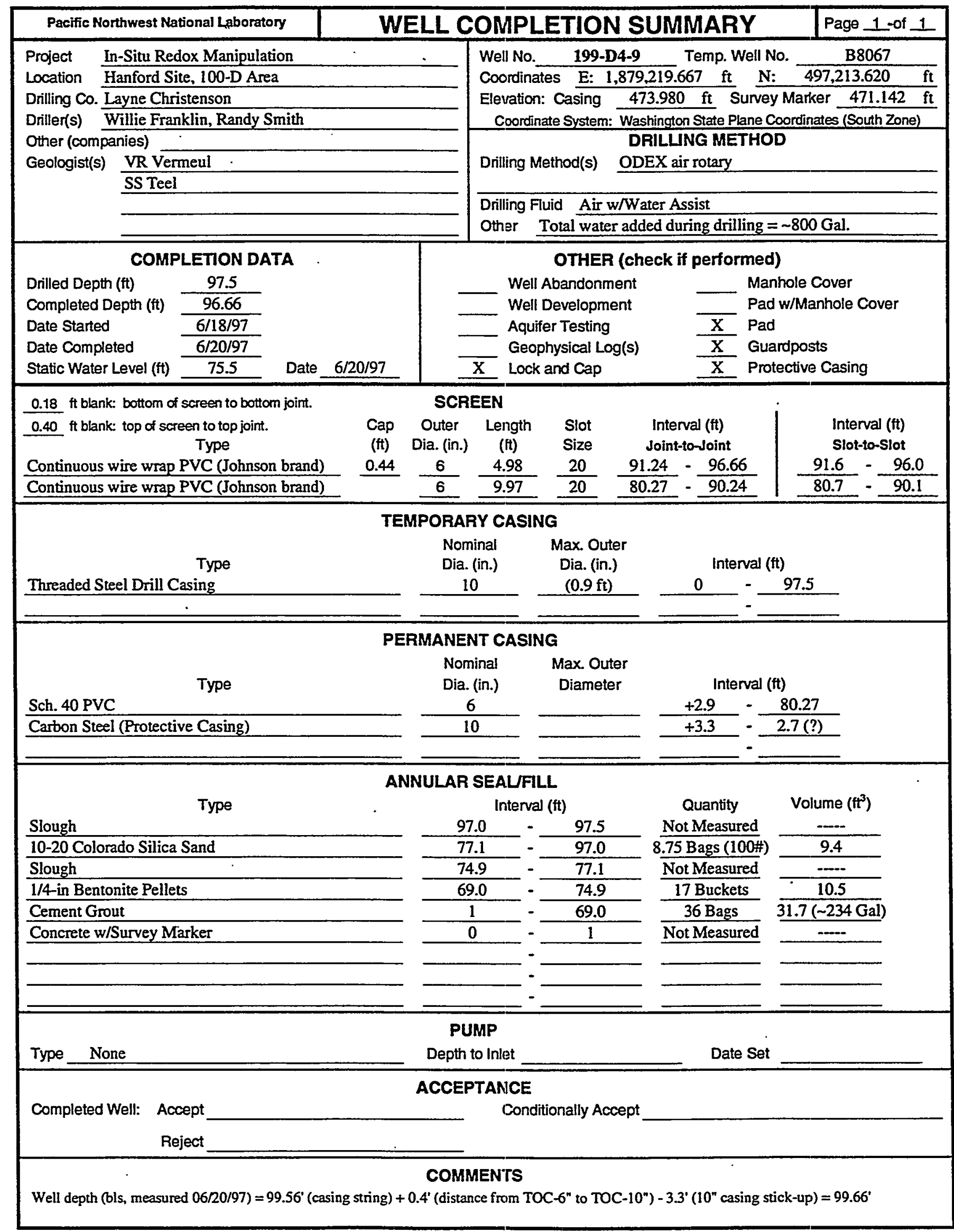

Reviewed by

Date

Depths are below land surface unless noted. 


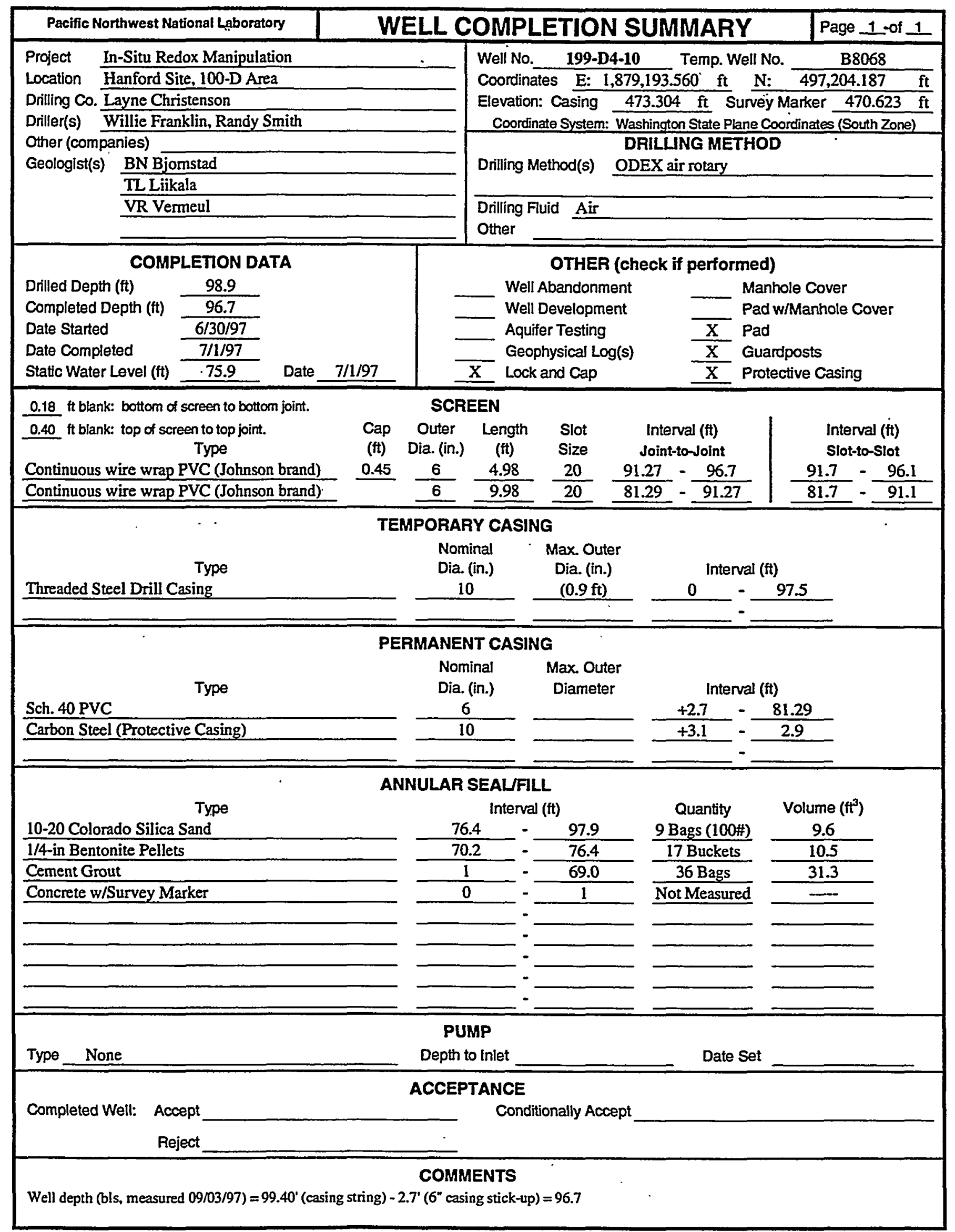

Reviewed by

Date

Depths are below land surface unless noted. 


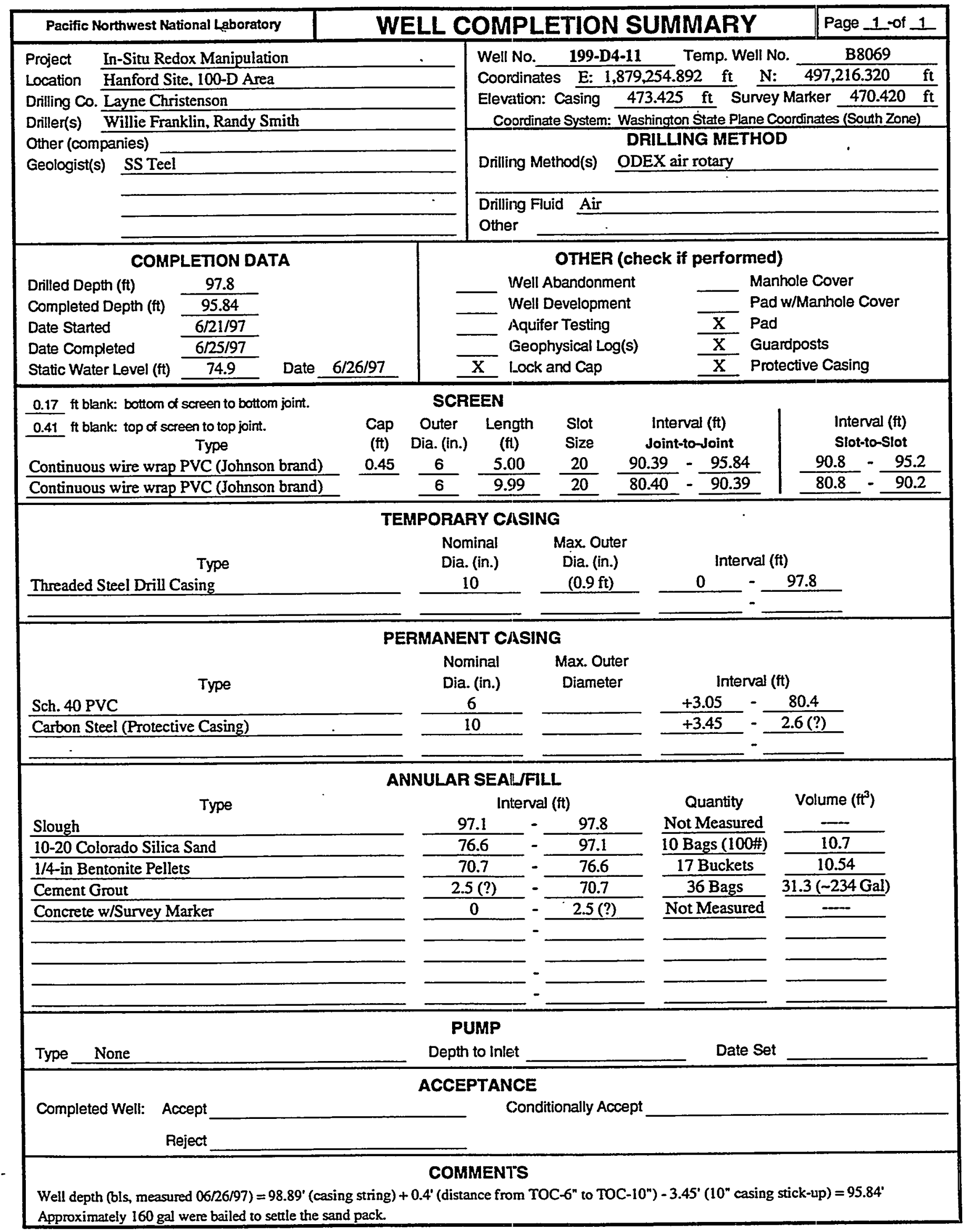

Reviewed by

Date

Depths are below land surface unless noted. 


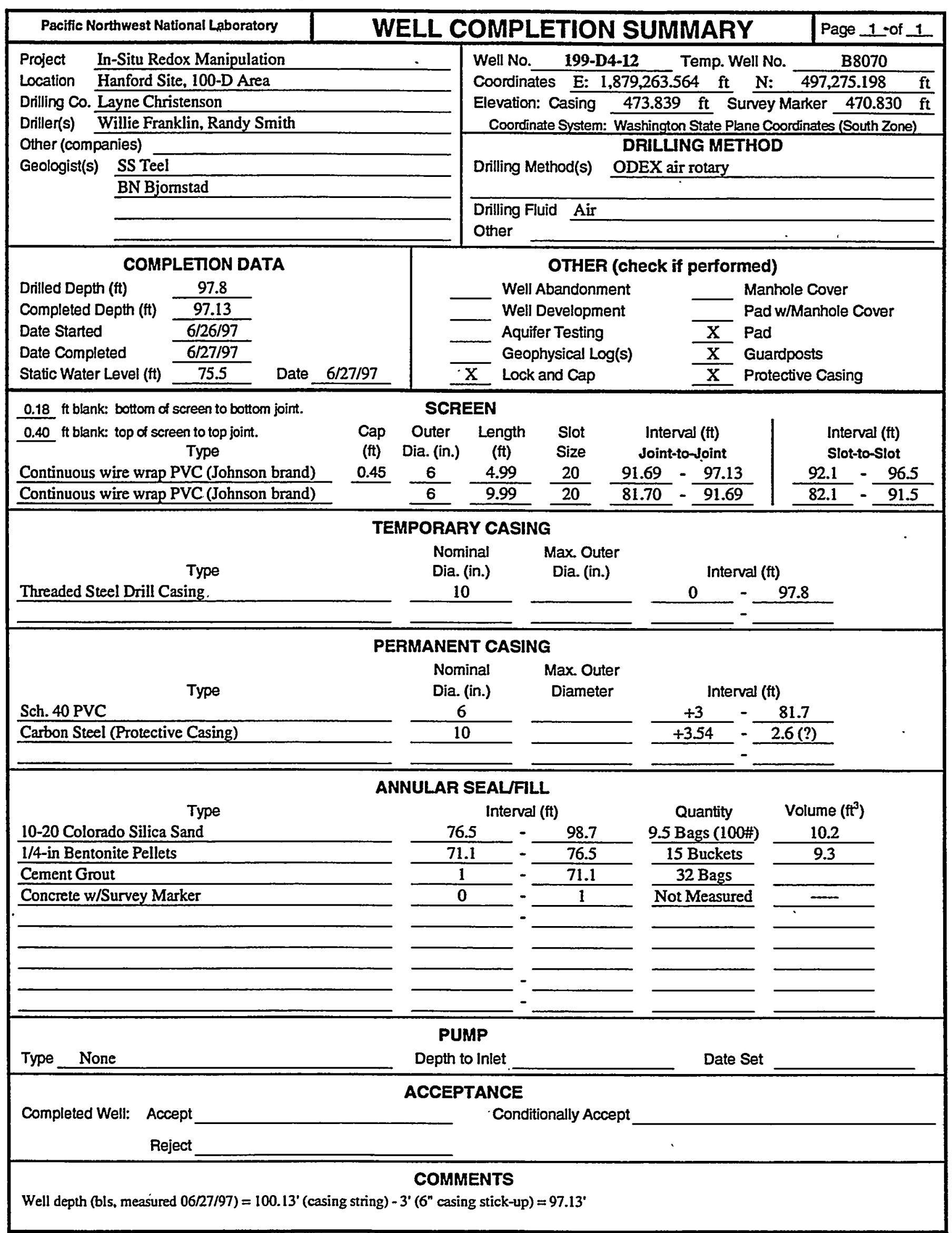

Reviewed by Date Depths are below land surface unless noted. 


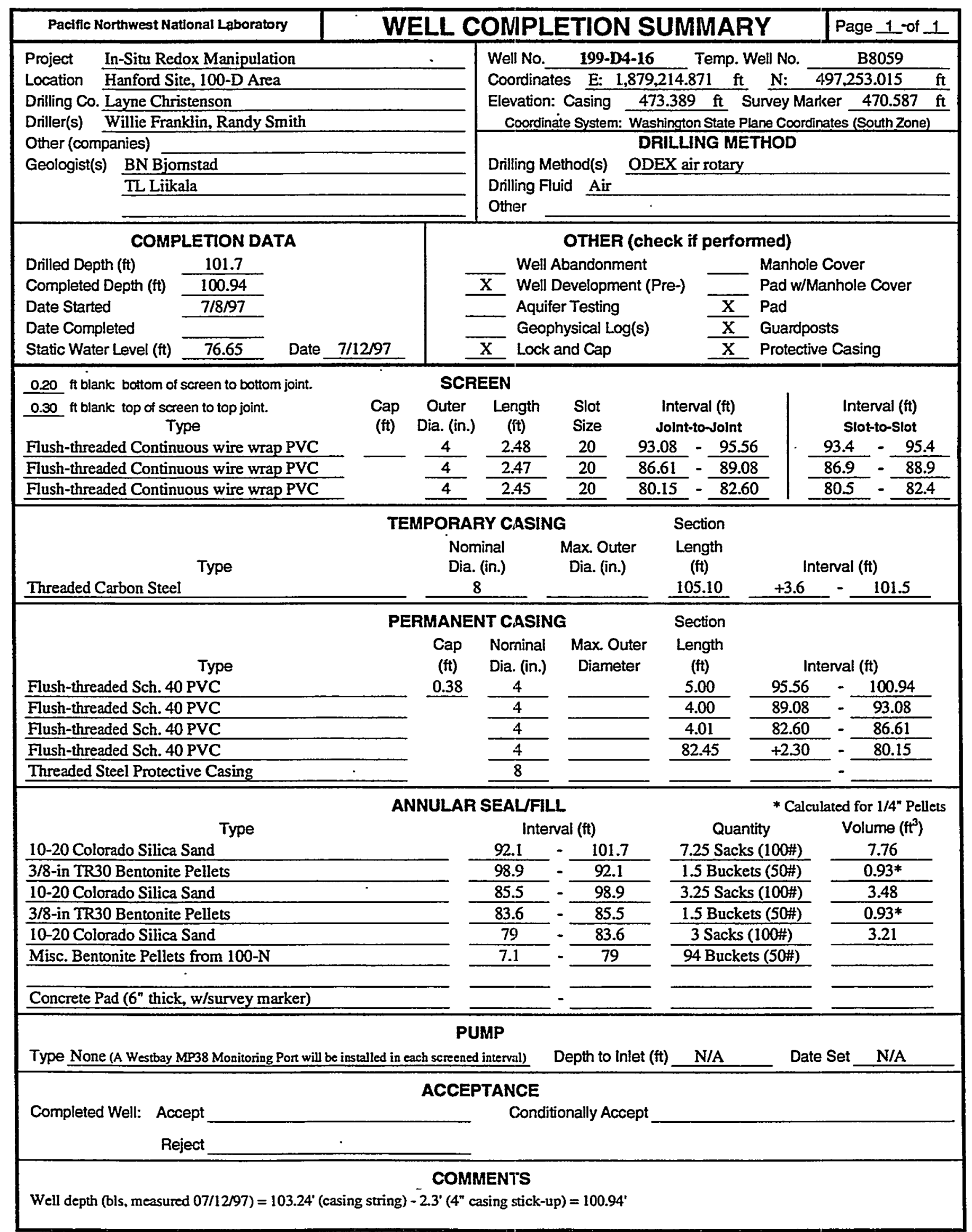

Reviewed by

Date

Depths are below land surface unless noted. 


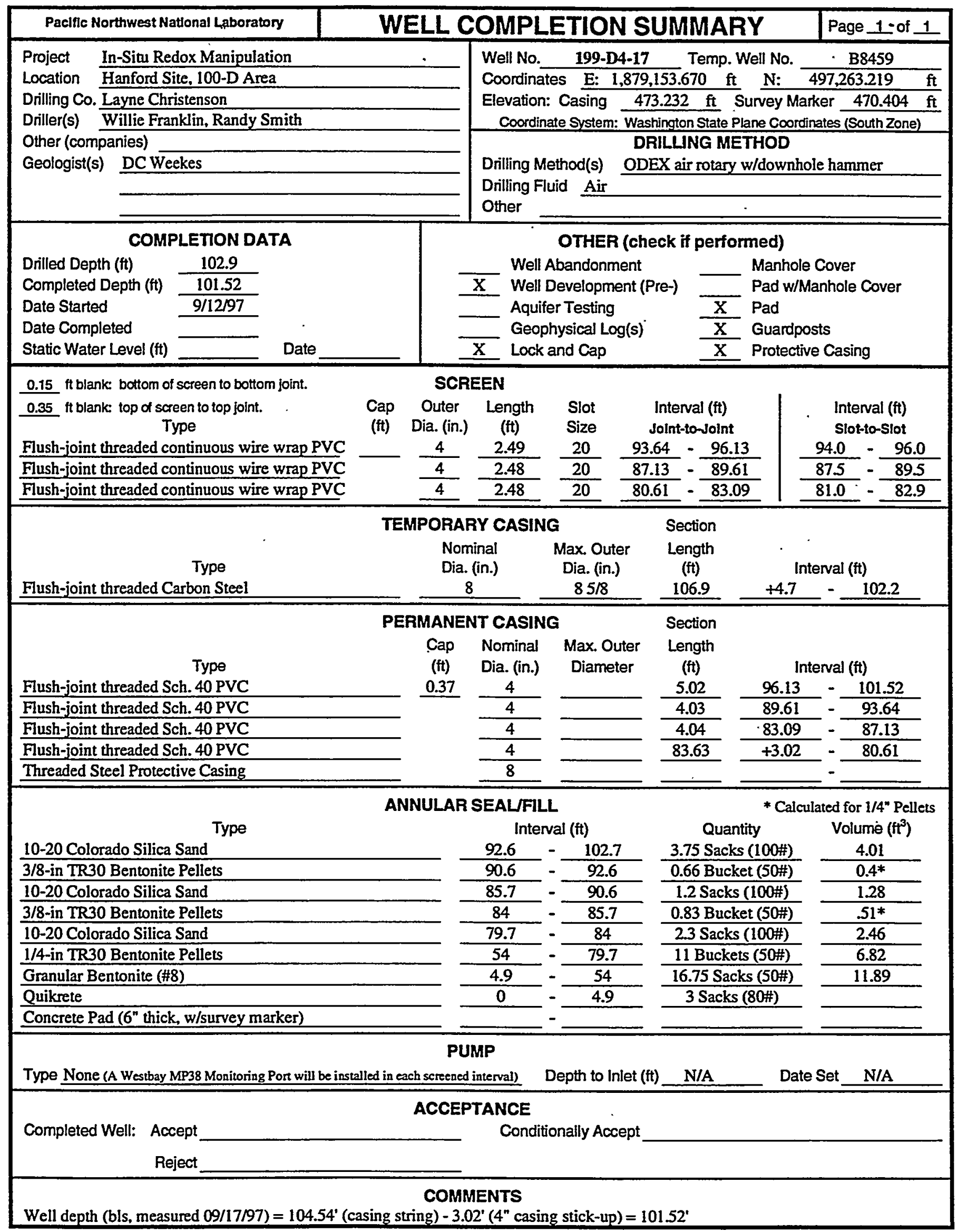

Reviewed by Date Depths are below land surface unless noted. 


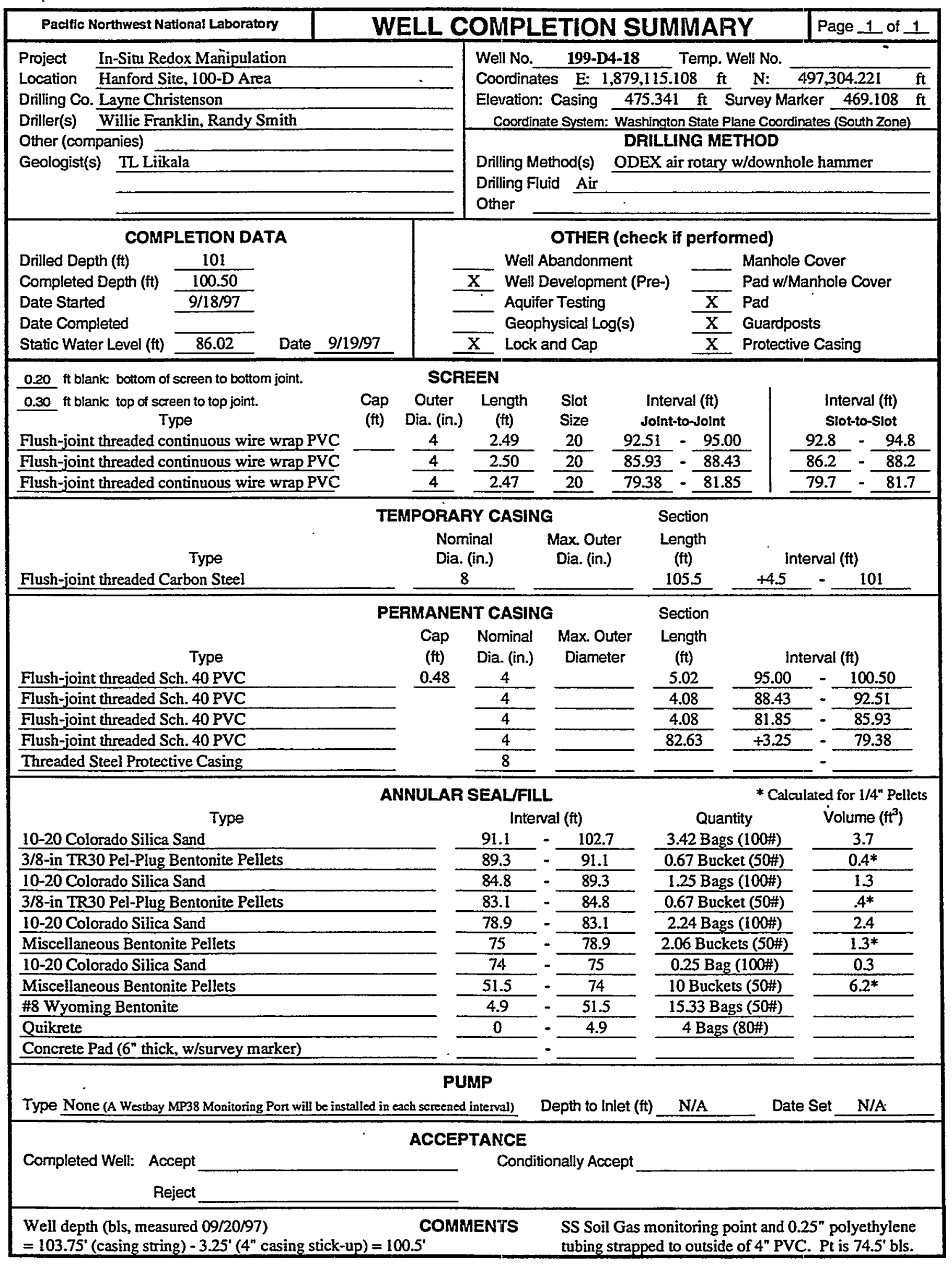

Reviewed by

Date

Deptfis are below land surface unless noted. 


\section{Appendix B}

Comparison of Pre- and Post-Injection Pumping Results

F. A. Spane Jr.

V.R. Vermeul

May 1998 
Limited Distribution

Letter Report

\section{$\underline{D R A F T}$}

Comparison of Pre- and Post-Injection Pumping Test Results for Evaluating Possible Hydrologic Property Changes at the 100-D Test Facility

Prepared by:

F. A. Spane, Jr.

V. R. Vermeul

Pacific Northwest National Laboratory

Richland, Washington 99352

Telephone: (509) 376-8329

Telefax: (509) 372-1704

E-mail: fa_spane@pnl.gov

May 1998

B.1 


\subsection{Executive Summary}

The primary objective of the In Situ REDOX Manipulation field remediation demonstration is to produce a reducing condition within the aquifer by "altering" the redox potential of iron-bearing minerals within the subsurface geologic framework from $\mathrm{Fe}^{+3}$ to $\mathrm{Fe}^{+2}$. The manipulated or fixed reduced-iron minerals can then react with redox-sensitive contaminants to precipitate or form less hazardous chemical forms. For this field demonstration, the targeted contaminant to be reduced was the mobile $\mathrm{Cr}^{+6}$ phase of chromium $\left(\mathrm{CrO}_{4}{ }^{2-}\right)$ within an identified contaminated groundwater plume located in the northern part of the Hanford Site (i.e., in the 100-D Area). A more detailed discussion of the contaminated area and aspects of the redox manipulation field demonstration are provided in Fruchter et al. (1997).

Since this demonstrated remediation technology relies on the continuing flow of contaminated groundwater through the created reactive geochemical wall, it is important to determine whether the applied technology (i.e., injection of the strong reducing agent) causes any significant changes in the subsurface hydrologic properties that could alter subsurface groundwater flow directions (e.g., through induced decreases in hydraulic properties within the reactive wall area). To assist in assessing the applied technology impacts, two constant-rate pumping tests were conducted at the 100-D field demonstration site to provide information that could be used to evaluate possible changes in subsurface hydrologic conditions. The pumping tests were conducted prior to and following injection and withdrawal of the strong geochemical reducing reagent, sodium diothionite. The pre- and post injection pumping test responses for the injection well (well D4-7) and surrounding seven observation wells were analyzed individually and compared to assess changes in the subsurface hydrologic conditions. Pertient findings of the test result comparisons are listed below:

\subsection{Pre-Injection Test Results (Homogeneous Model)}

1. Analysis of individual well test results indicate the following range and mean values for selected hydrologic properties for the aquifer prior to injection of the sodium diothionite:

\begin{tabular}{|c|c|c|}
\hline & Range & Mean $( \pm 1 \sigma)$ \\
\hline Hydraulic Conductivity, $\mathrm{K}_{\mathrm{h}}$ & $40.7-62.1 \mathrm{ft} / \mathrm{d}$ & $54.5 \pm 6.93 \mathrm{ft} / \mathrm{d}$ \\
\hline Vertical Anisotropy, $\mathrm{K}_{\mathrm{v}} / \mathrm{K}_{\mathrm{h}}$ : & $0.006-0.031$ & $0.015 \pm 0.010$ \\
\hline Storativity, S: & $0.0017-0.0058$ & $0.0040 \pm 0.0017$ \\
\hline Specific Yield, $S_{y}:$ & $0.014-0.031$ & $0.020 \pm 0.0063$ \\
\hline
\end{tabular}

2. While certain groupings of observation wells provide a consistent "composite" analysis result, the range in hydraulic conductivity exhibit for all analysis results suggests that horizontal anisotropic conditions likely exist in the aquifer (i.e., $\mathrm{K}_{\mathrm{x}} \mathrm{K}_{\mathrm{y}}$ ).

3. Comparison of test responses for multi-level observation wells (i.e., well D4-2 Upper and Lower Zone, and D4-3 Upper and Lower Zone) suggests a vertical heterogeneous or multi-layered system for the test aquifer. 


\subsection{Post Injection Test Results (Homogeneous Model)}

1. Comparison of pre- and post injection test responses indicate several discernable effects associated with the redox experiment. The recognized effects include:

a) formation of a significant skin effect or zone of reduced permeability immediately surrounding the injection well (well D4-7)

b) a slight increase in formation hydraulic conductivity was exhibited for most observation well post injection test responses

2. The observed post injection response is consistent with a conceptual model where permeability of the aquifer is enhanced areally by chemical and dissolution reactions of the injected redox reagent, while a zone of reduced permeability (i.e., well skin) is produced around the injection well during the reagent withdrawal phase. The skin developed can be visualized as forming around the well due to entrapment of colloidal particulates within the converging pumpback fluids, which were mobilized during the injection phase.

3. The presence of a zone of reduced permeability surrounding the injection well (following injection and withdrawal of the reducing reagent) is supported by significantly greater drawdown observed at the injection well and delayed time response exhibited at most of the observation well locations during the post injection pumping test.

4. The extent and severity of the zone of permeability reduction surrounding the injection well can not be determined uniquely by comparing pre- and post test responses (i.e., different combinations of skin thickness and permeability can produce similar test responses). However if it is assumed that the skin formed and was limited to region of the sand-pack installation surrounding the well screen (a plausible explanation due to convergent flow and to possible changes in sand pack and formation hydraulic properties), then a skin zone with a permeability $1 / 20^{\text {th }}$ that of the aquifer surrounding the injection well location is indicated (i.e., $2.69 \mathrm{ft} / \mathrm{d}$ versus $56.7 \mathrm{ft} / \mathrm{d}$ ).

5. A comparison of pre- and post injection observation well test results also indicates a slight decrease in recovery response at most observation well locations. This decreased test response suggests a slight increase in inter-well hydraulic conductivity caused by the injection/withdrawal of the reducing reagent. As noted previously, this observation is consistent with a conceptual model associated with dissolution mobilization processes associated with administering and removal of the redox reagent. 


\subsection{References/Bilbiography}

Fruchter, J.S., .E. Amonette, C.R. Cole, Y.A. Gorby, M.D. Humphrey, J.D. Isok, F.A. Spane, J.E. Szecsody, S.S. Teel, V.R. Vermeul, M.D. Williams, and S.B. Yabusaki. 1996. In Situ Redox. Manipulation Field Injection Test Report - Hanford 100-H Area. Pacific Northwest National Laboratory, PNNL-11372, Richland, Washington.

Fruchter, J.S., M.D. Williams, V.R. Vermeul, C.R. Cole, and S.S. Teel. 1997. Treatability Test P for In Situ REDOX Manipulation in the 100-HR-3 Operable Unit D-Area, Pacific Northwest Natio Laboratory, Richland, Washington.

Liu, W. and J.J. Butler, Jr. 1995. The KGS Model for Slug Tests in Partially Penetrating Wells. Kansas Geological Survey Computer Series Rept. 95-1, Lawrence, Kansas.

Peres, A. M., M. Onur, and A.C. Reynolds. 1989. A New Analysis Procedure for

Determining Aquifer Properties From Slug Test Data. Water Resources Research, v. 25, no. 7, pp 1602.

Spane, F.A., Jr., and S.K. Wurstner. 1993. DERIV: A Program for Calculating Pressure Derivati for Use in Hydraulic Test Analysis. Ground Water. v. 31, no. 5, pp. 814-822.

Vermeul, V.R., S.S. Teel, J.E. Amonette, C.R. Cole, J.S. Fruchter, Y.A. Gorby, F.A. Spane, J.E. Szecsody, M.D. Williams, and S.B. Yabusaki. 1995. Geologic, Geochemical, Microbiologic, an Hydrologic Characterization at the In Situ Redox. Manipulation Test Site. Pacific Northwest Laboratory, PNL-10633, Richland, Washingtion. 
Table 1. Pertinent Well Completion and Distance Aspects for 100-D Wells

\begin{tabular}{|c|c|c|c|c|c|}
\hline Well Site & $\begin{array}{c}\text { Distance } \\
\text { from D4-7 } \\
\mathrm{ft}\end{array}$ & $\begin{array}{c}\text { Azimuth } \\
\text { From D4-7 } \\
\text { Degrees* }\end{array}$ & $\begin{array}{l}\text { Well Screen } \\
\text { Diameter } \\
\mathrm{ft}\end{array}$ & $\begin{array}{c}\text { Well Screen } \\
\text { Completion } \\
\text { top/bottom } \\
\text { ft bls }\end{array}$ & $\begin{array}{l}\text { Well Screen } \\
\text { Completion } \\
\text { in aquifer } \\
\mathrm{ft} \mathrm{bla}^{* *}\end{array}$ \\
\hline D4-1 & 36.3 & 135 & 0.250 & $\begin{array}{l}74.65 \\
94.67\end{array}$ & $\begin{array}{c}0.0 \\
14.11\end{array}$ \\
\hline $\begin{array}{c}\text { D4-2 } \\
\text { Upper Zone }\end{array}$ & 34.3 & 316 & 0.167 & $\begin{array}{l}83.65 \\
88.6 \\
\end{array}$ & $\begin{array}{l}3.09 \\
8.04 \\
\end{array}$ \\
\hline $\begin{array}{c}\text { D4-2 } \\
\text { Lower Zone }\end{array}$ & 34.3 & 316 & 0.167 & $\begin{array}{l}93.65 \\
99.0 \\
\end{array}$ & $\begin{array}{r}13.09 \\
15.94 \\
\end{array}$ \\
\hline $\begin{array}{c}\text { D4-3 } \\
\text { Upper Zone }\end{array}$ & 24.0 & 315 & 0.167 & $\begin{array}{l}83.5 \\
88.5 \\
\end{array}$ & $\begin{array}{l}2.94 \\
7.94 \\
\end{array}$ \\
\hline $\begin{array}{c}\text { D4-3 } \\
\text { Lower Zone }\end{array}$ & 24.0 & 315 & 0.167 & $\begin{array}{l}93.5 \\
98.8 \\
\end{array}$ & $\begin{array}{r}12.94 \\
15.94 \\
\end{array}$ \\
\hline D4-4 & 69.9 & 107 & 0.167 & $\begin{array}{l}78.06 \\
98.4 \\
\end{array}$ & $\begin{array}{c}0.0 \\
15.94 \\
\end{array}$ \\
\hline D4-7 & 0 & 0 & 0.250 & $\begin{array}{l}80.2 \\
95.6 \\
\end{array}$ & $\begin{array}{c}0.0 \\
15.04 \\
\end{array}$ \\
\hline D4-8 & 9.2 & 30 & 0.167 & $\begin{array}{l}75.43 \\
95.4 \\
\end{array}$ & $\begin{array}{r}0.0 \\
14.84 \\
\end{array}$ \\
\hline D4-9 & 27.5 & 252 & 0.250 & $\begin{array}{l}81.3 \\
96.7 \\
\end{array}$ & $\begin{array}{l}0.74 \\
15.94 \\
\end{array}$ \\
\hline D4-11 & 28.1 & 20 & 0.250 & $\begin{array}{l}80.26 \\
95.7 \\
\end{array}$ & $\begin{array}{c}0.0 \\
15.14 \\
\end{array}$ \\
\hline D4-12 & 50.0 & 45 & 0.250 & $(-)$ & $(-)$ \\
\hline $\begin{array}{ll}* & \text { measu } \\
* * & \mathrm{ft} \text { bel } \\
(-) & \text { assum } \\
\end{array}$ & $\begin{array}{l}\text { ounterclo } \\
\text { aquifer tc } \\
\text { o be full }\end{array}$ & $\begin{array}{l}\text { from due } \\
\text { bla); aquife } \\
\text { etrating }\end{array}$ & $\begin{array}{l}\text { ast (East }= \\
\text { thickness }=1\end{array}$ & $\begin{array}{l}\text { degrees) } \\
.94 \mathrm{ft}\end{array}$ & \\
\hline
\end{tabular}


Table 2. Pre-Injection Hydraulic Property Analysis Results Using ISOAQX and WTAQ3 Analytical Models

\begin{tabular}{|c|c|c|c|c|c|c|c|c|}
\hline \multirow[b]{2}{*}{ Well Site } & \multicolumn{2}{|c|}{$\underset{\mathrm{ft} / \mathrm{d}}{\mathbf{K}_{\mathrm{h}}}$} & \multicolumn{2}{|c|}{$\mathbf{K}_{\mathbf{D}}$} & \multicolumn{2}{|c|}{$\mathbf{S}$} & \multicolumn{2}{|c|}{$S_{y}$} \\
\hline & Isoaqx & Wtâ & Isoaqx & Wtag & Isoaqx & AYta 9 & Isoaq $\mathrm{x}$ & Wtag 3 \\
\hline D4-1 & 76.2 & sons & .009 & W & .0104 & 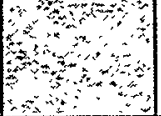 & .0270 & +8 \\
\hline $\begin{array}{c}\text { D4-2 } \\
\text { Upper Zone }\end{array}$ & 59.8 & $\begin{array}{r}5 \\
59.8 \\
4 \\
4\end{array}$ & .008 & $\begin{array}{r}\mid \\
009 \% \\
0 \\
y \\
y\end{array}$ & .0055 & $\begin{array}{r}0050 \\
0 \\
0\end{array}$ & .0184 & 0184 \\
\hline $\begin{array}{c}\text { D4-2 } \\
\text { Lower Zone }\end{array}$ & 54.8 & $\begin{array}{r}548 \\
548 \\
4\end{array}$ & .029 & $\begin{array}{r}0 \\
031 \\
03 \\
01\end{array}$ & .0061 & 0058 & .0253 & 0253 \\
\hline $\begin{array}{c}\text { D4-3 } \\
\text { Upper Zone }\end{array}$ & 62.1 & 621 & .006 & o $06 \%$ & .0056 & 0054 & .0134 & 00139 \\
\hline $\begin{array}{c}\text { D4-3 } \\
\text { Lower Zone }\end{array}$ & 55.2 & $\begin{array}{r}552 \\
-55 \\
65\end{array}$ & .025 & $\begin{array}{r}0 \\
029 \\
029 \\
0\end{array}$ & .0053 & $\begin{array}{r}0050 \\
0 \\
000\end{array}$ & .0166 & 0165 \\
\hline D4-4 & 105.3 & & .011 & & .0140 & (1) & .032 & \\
\hline D4-7 & 47.7 & 567 & .047 & & .0098 & 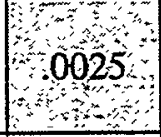 & .170 & 0306 \\
\hline D4-8 & 30.8 & $\begin{array}{r}40.7 \\
40 \\
4\end{array}$ & .030 & $\begin{array}{l}x 10 \\
1101 \\
0101\end{array}$ & .0034 & 00019 & .081 & 0230 \\
\hline D4-9 & 50.3 & $\begin{array}{r}49 \\
519 \\
9\end{array}$ & .010 & $\begin{array}{r}4 \\
010 \\
0 \\
0\end{array}$ & .0027 & 0025 & .015 & $\begin{array}{r}0138 \\
0\end{array}$ \\
\hline D4-11 & 40.2 & 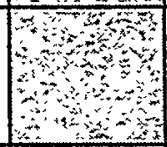 & .024 & and & .0080 & 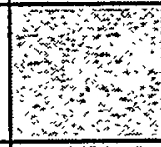 & .057 & $\begin{array}{r}x \\
-\gamma \\
0\end{array}$ \\
\hline D4-12 & 73.4 & and & .014 & ond & .0125 & $\frac{1}{2}$ & .047 & ond \\
\hline
\end{tabular}


Table 3. Comparison of Post- to Pre-Experiment Pumping Test Recovery Buildup Responses

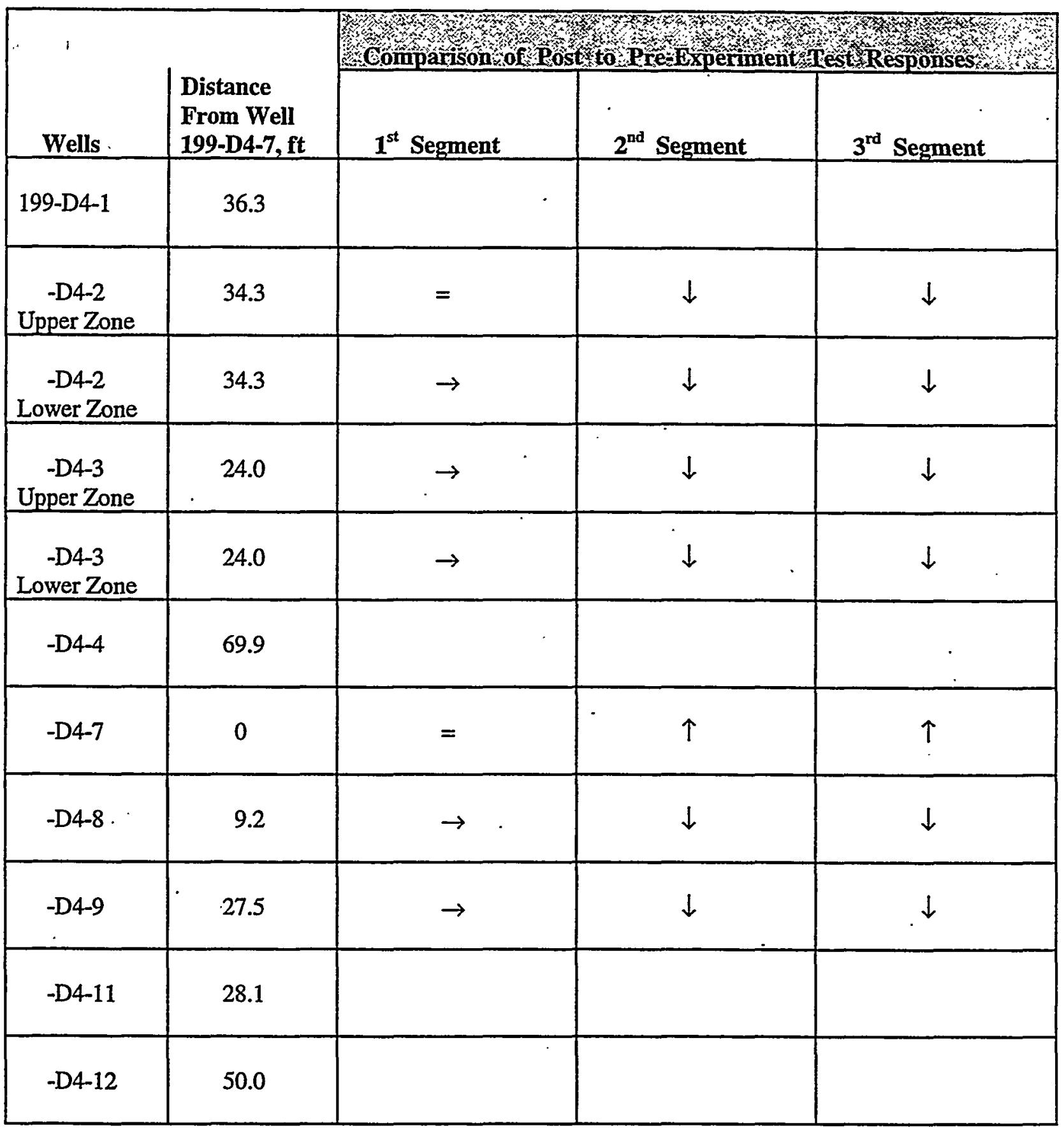

Symbol Definition:

$\rightarrow \quad$ Post experiment time response exhibits a delay (i.e., shift to the right)

$\leftarrow \quad$ Post experiment time response exhibits an advance (i.e., shift to the left)

$\uparrow \quad$ Post experiment buildup response exhibits an increase (i.e., shift upward)

$\downarrow \quad$ Post experiment buildup response exhibits a decrease (i.e., shift downward)

$=\quad$ Post experiment time/buildup response exhibits no change 
Table 4. Pre- and Post-Injection Hydraulic Property Analysis Results Using WTAQ3 Analytical Model

\begin{tabular}{|c|c|c|c|c|c|c|c|c|c|c|}
\hline \multirow[b]{2}{*}{ Well Site } & \multicolumn{2}{|c|}{$K_{h}(f t / d)$} & \multicolumn{2}{|c|}{$\mathbf{K}_{\mathbf{D}}$} & \multicolumn{2}{|c|}{$\mathbf{S}$} & \multicolumn{2}{|c|}{$\mathbf{S}_{\mathbf{y}}$} & \multicolumn{2}{|c|}{$\mathbf{S}_{\mathrm{k}}$} \\
\hline & Pre & Post & Pre & Post & Pre & ots & Pre & $\begin{array}{l}\text { How } \\
\text { Post }\end{array}$ & Pre & Post \\
\hline D4-1 & & 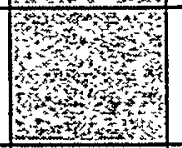 & & 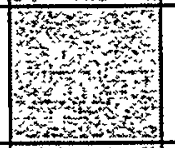 & & 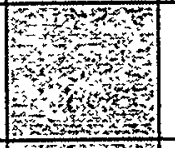 & & 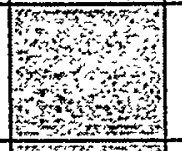 & 0 & 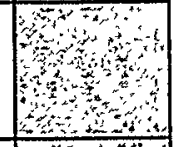 \\
\hline $\begin{array}{c}\text { D4-2 } \\
\text { Upper Zone }\end{array}$ & 59.8 & 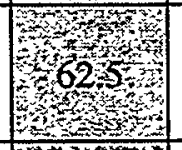 & .009 & 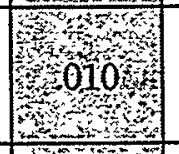 & .0050 & 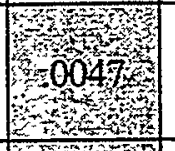 & .0184 & 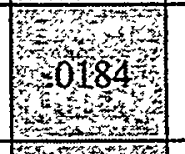 & 0 & 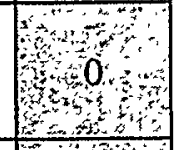 \\
\hline $\begin{array}{c}\text { D4-2 } \\
\text { Lower Zone }\end{array}$ & 54.8 & 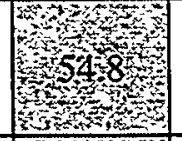 & .031 & 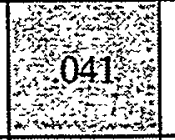 & .0058 & 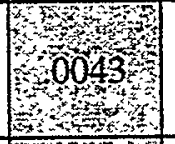 & .0253 & 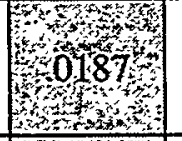 & 0 & 作, \\
\hline $\begin{array}{c}\text { D4-3 } \\
\text { Upper Zone }\end{array}$ & 62.1 & 6003 & .006 & 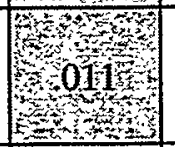 & .0054 & 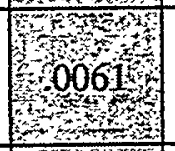 & .0139 & $\begin{array}{l}\text { W } \\
0198 \\
0\end{array}$ & 0 & $\begin{array}{l}6 \\
460 \\
40 \\
4\end{array}$ \\
\hline $\begin{array}{c}\text { D4-3 } \\
\text { Lower Zone }\end{array}$ & 55.2 & $\begin{array}{l}3 \\
588 \\
5\end{array}$ & .029 & a & .0050 & $\begin{array}{r}10046 \\
0040\end{array}$ & .0166 & 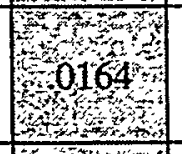 & 0 & 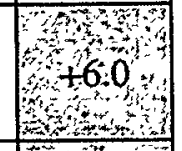 \\
\hline D4-4 & & 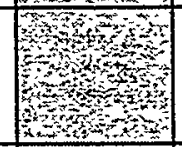 & & 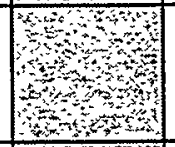 & & 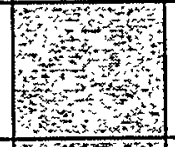 & & of & 0 & 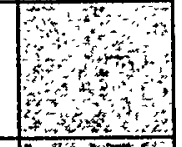 \\
\hline D4-7 & 56.7 & 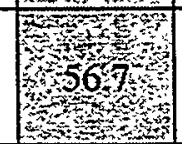 & .010 & $\begin{array}{c}\text { wos } \\
010 \\
010 \\
y\end{array}$ & .0025 & 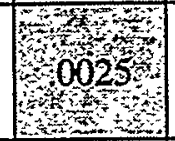 & .0306 & 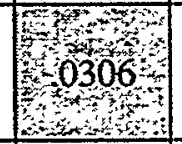 & 0 & 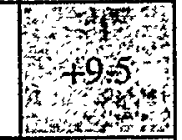 \\
\hline D4-8 & 40.7 & 3y & .010 & ats & .0017 & woo & .0235 & Fon & 0 & 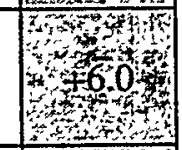 \\
\hline D4-9 & 51.9 & 15 & .010 & 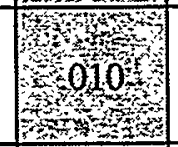 & .0025 & Fot & .0141 & 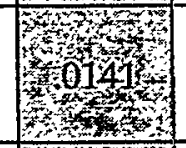 & 0 . & 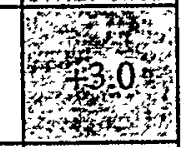 \\
\hline D4-11 & & $\begin{array}{l}3 \\
3 \\
3\end{array}$ & & 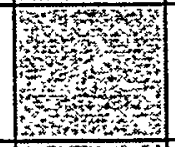 & & 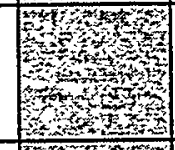 & & 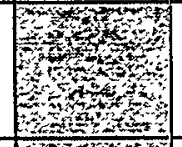 & 0 & 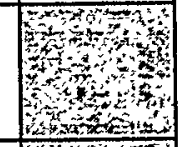 \\
\hline$D 4-12$ & & $\frac{1}{56-1}$ & & (3) & & 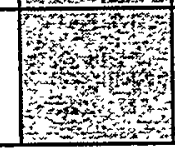 & & 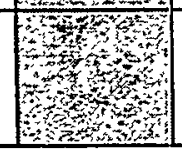 & 0 & 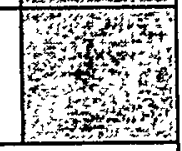 \\
\hline
\end{tabular}




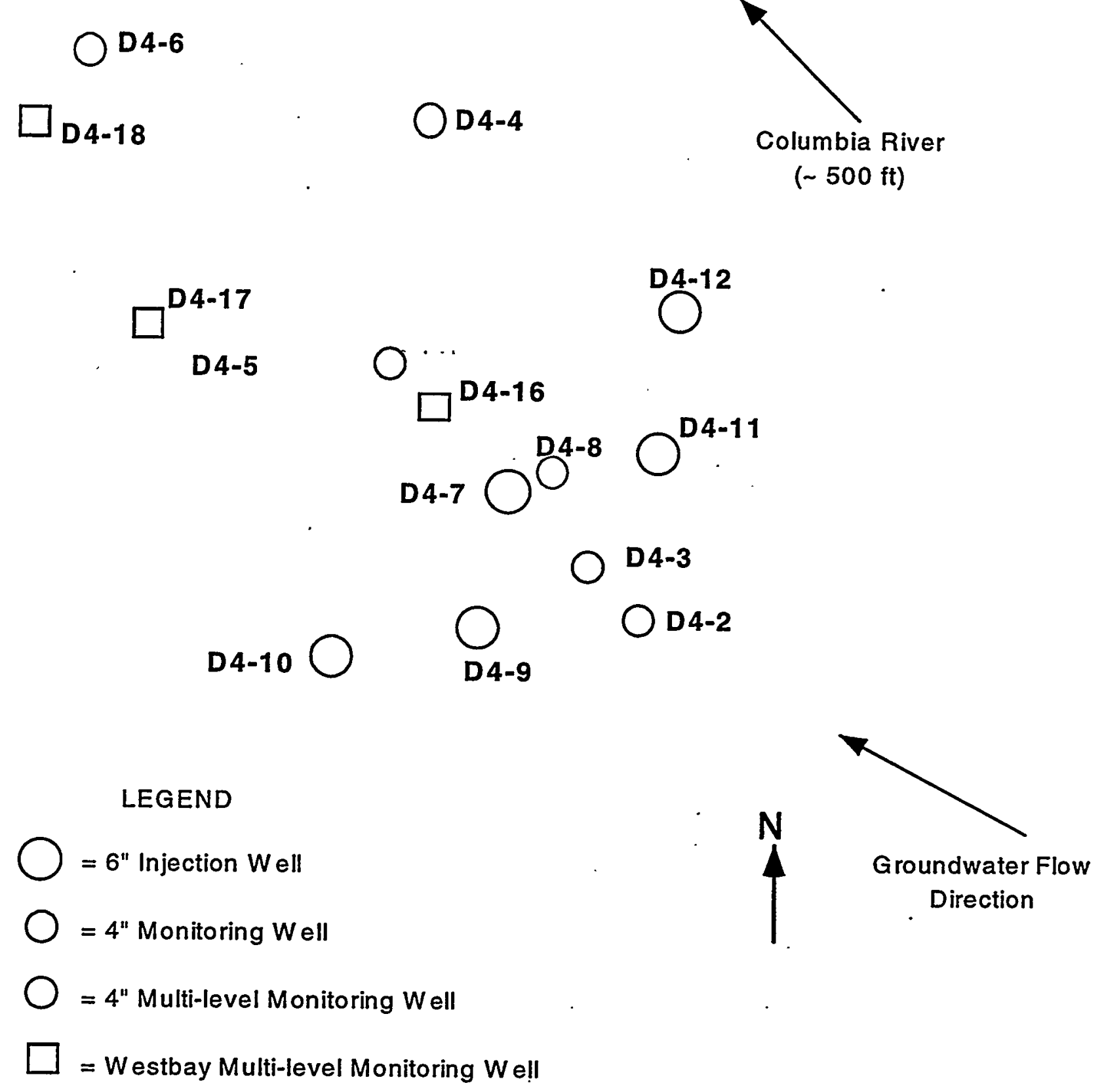

Note: Drawing not to scale. Locations are approximate.

Figure 1. Schematic Layout of 100-D Test Well Facility 
5.0 Pre-Injection Test Analysis Plots 


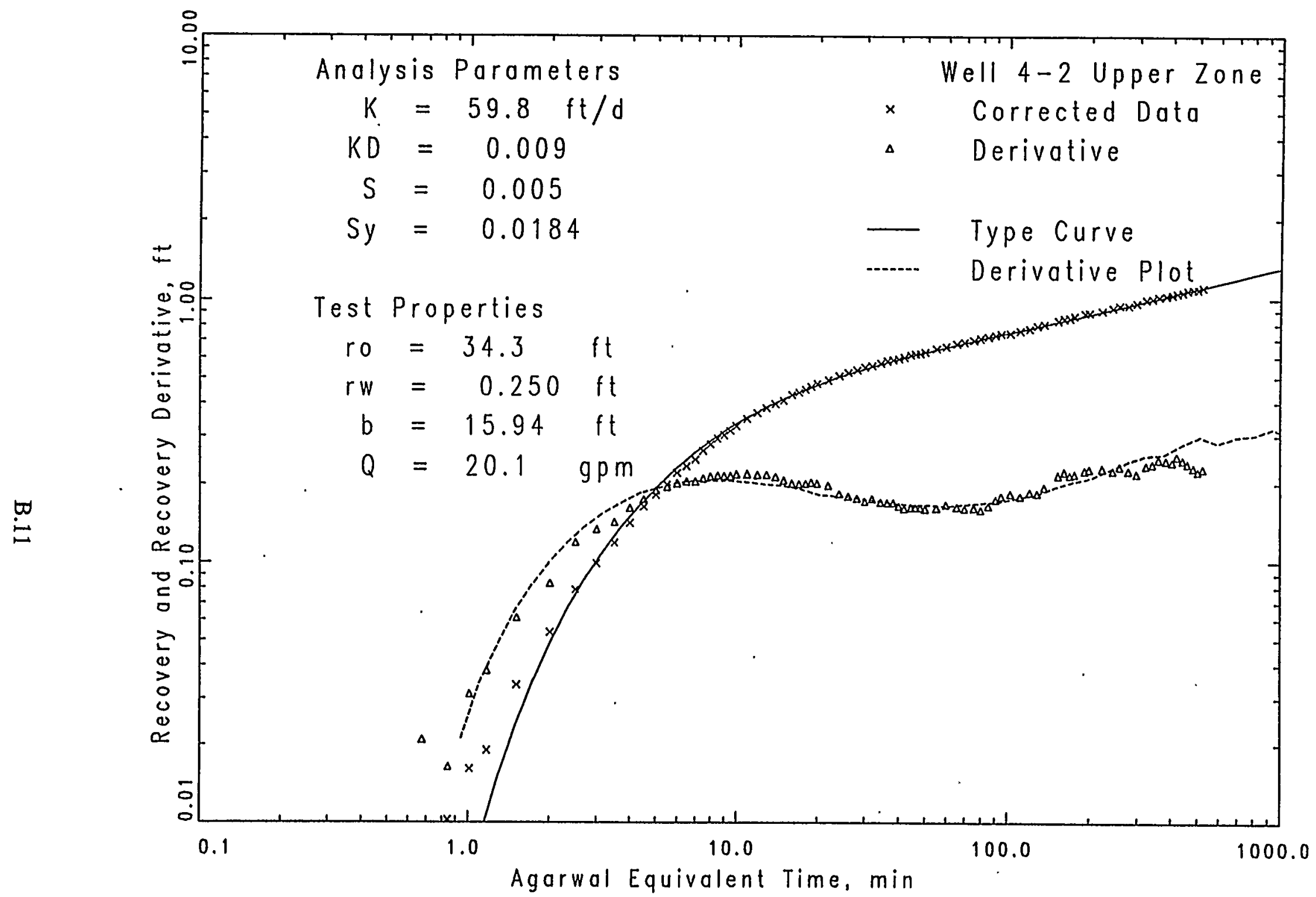

Figure 5.1. Pre-Injection Pumping Test Recovery Analysis Plot for Well D4-2 Upper Zone 


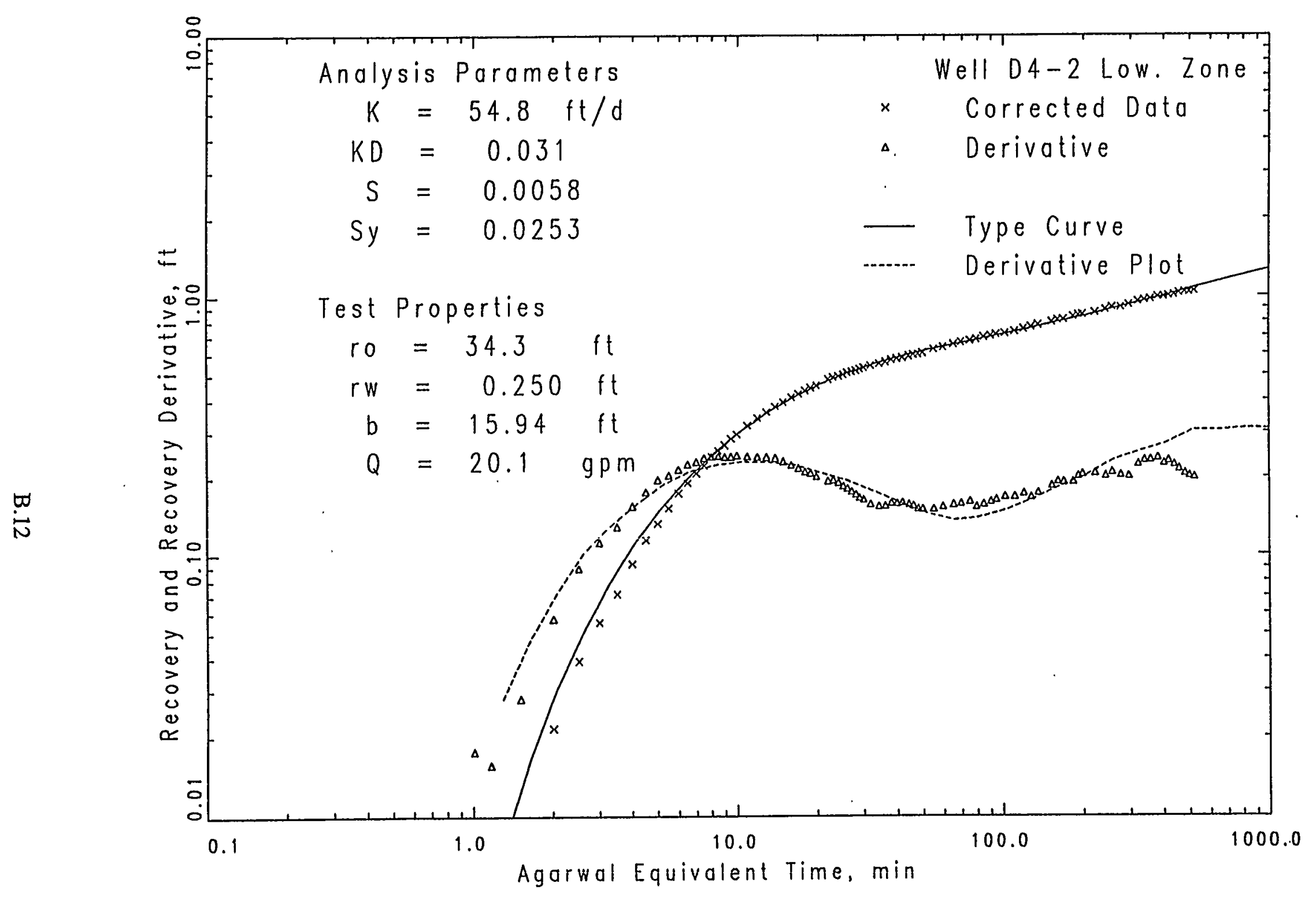

Figure 5.2. Pre-Injection Pumping Test Recovery Analysis Plot for Well D4-2 Lower Zone 


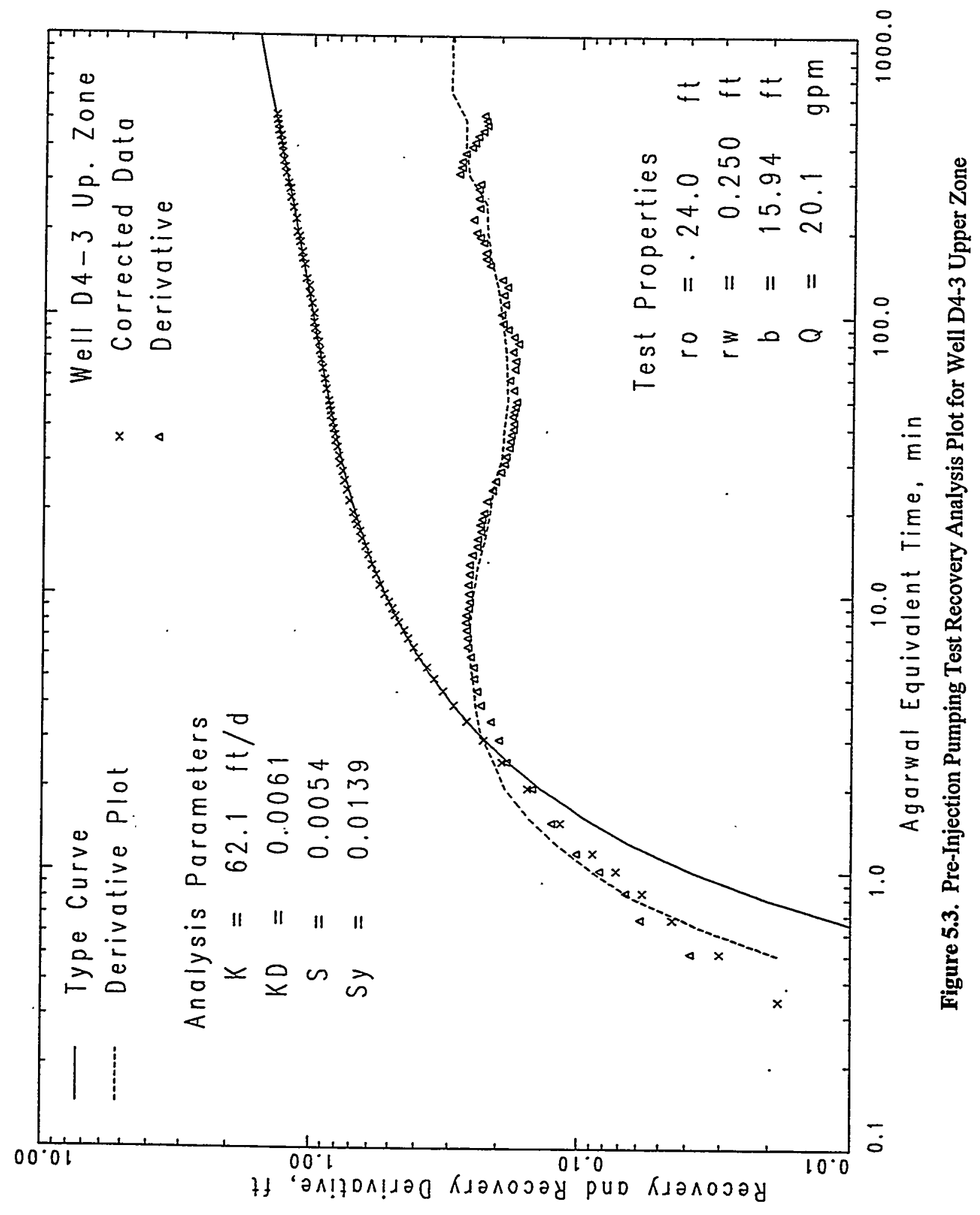

B. 13 


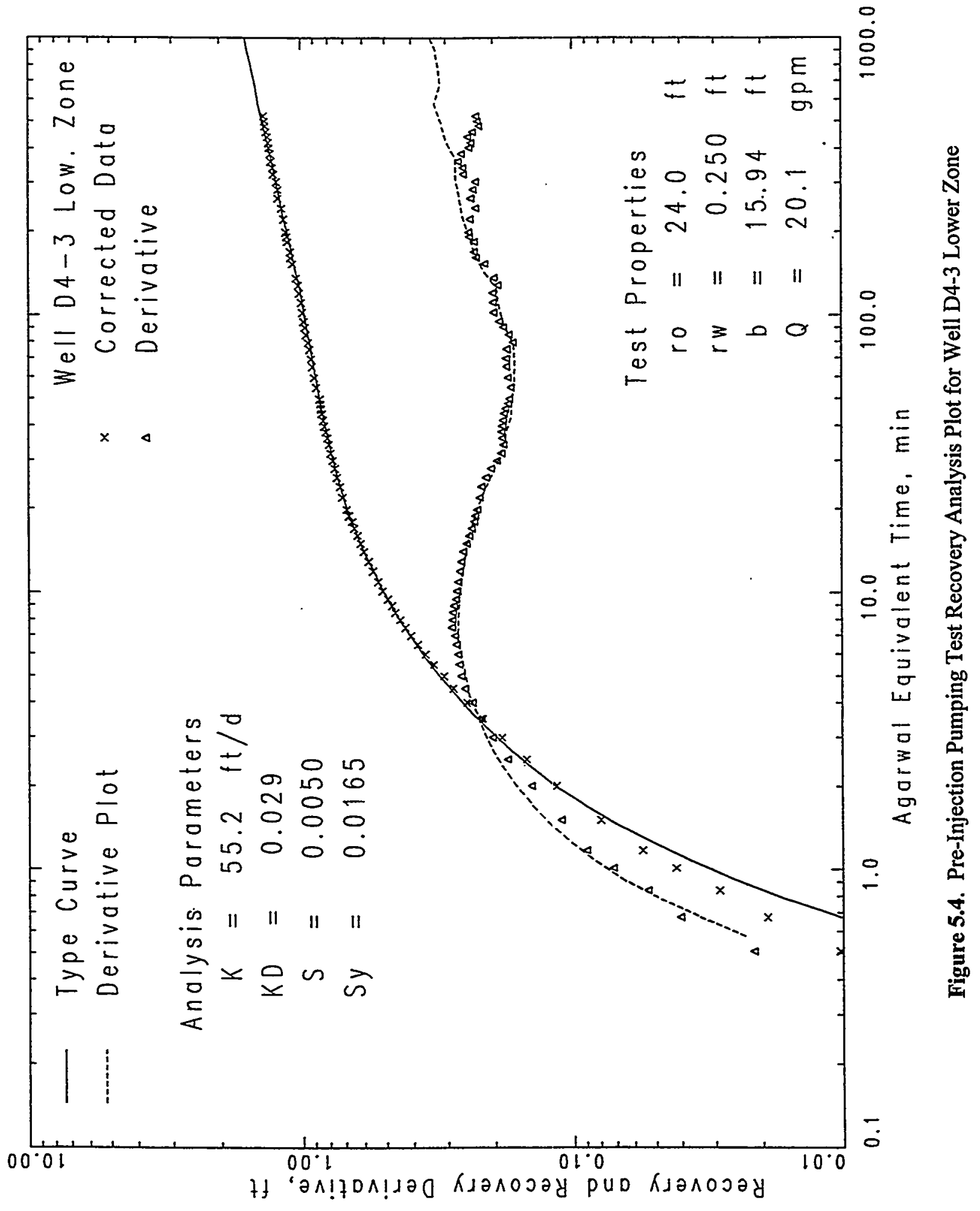




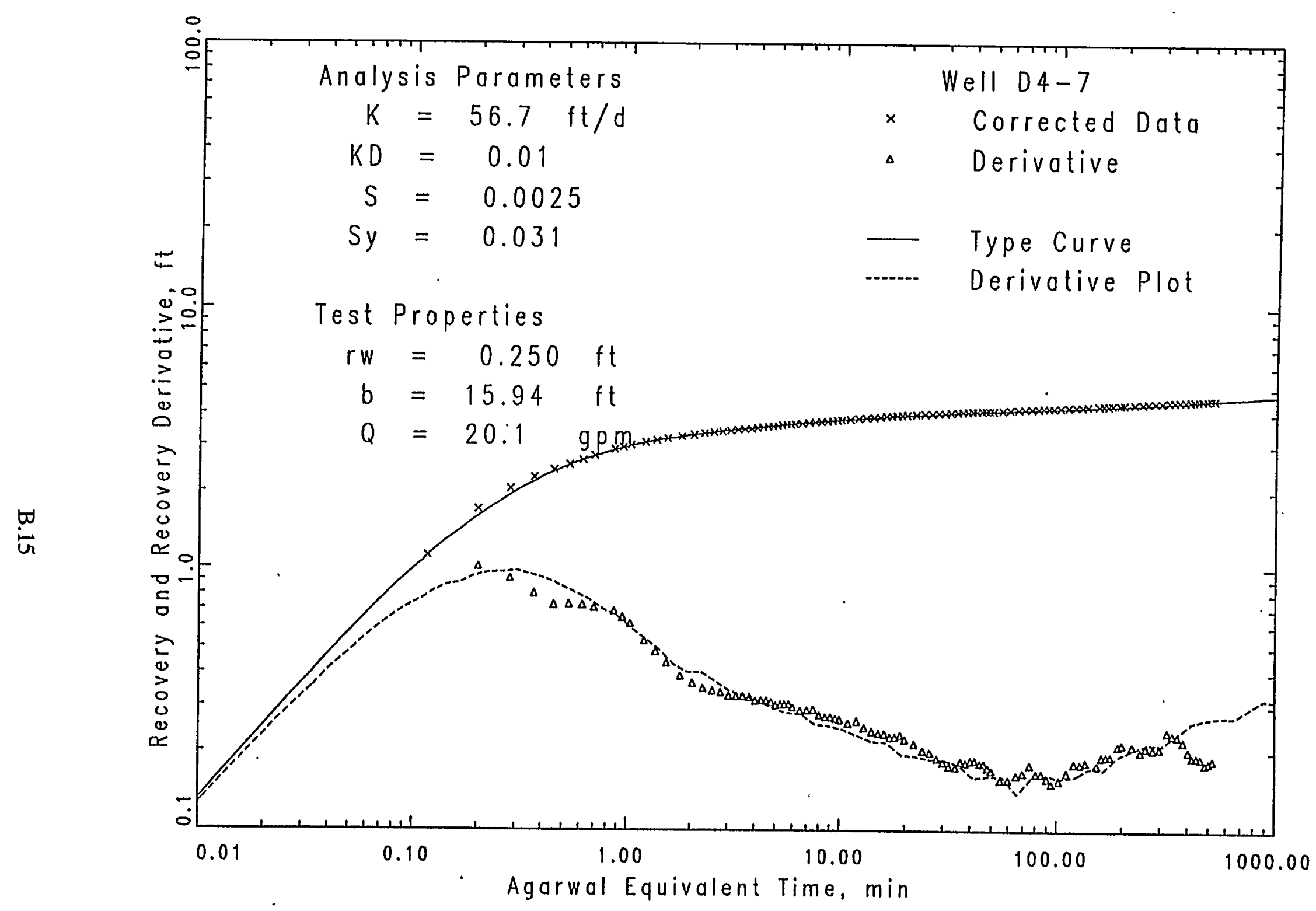

Figure 5.5. Pre-Injection Pumping Test Recovery Analysis Plot for Well D4-7 (Injection Well) 


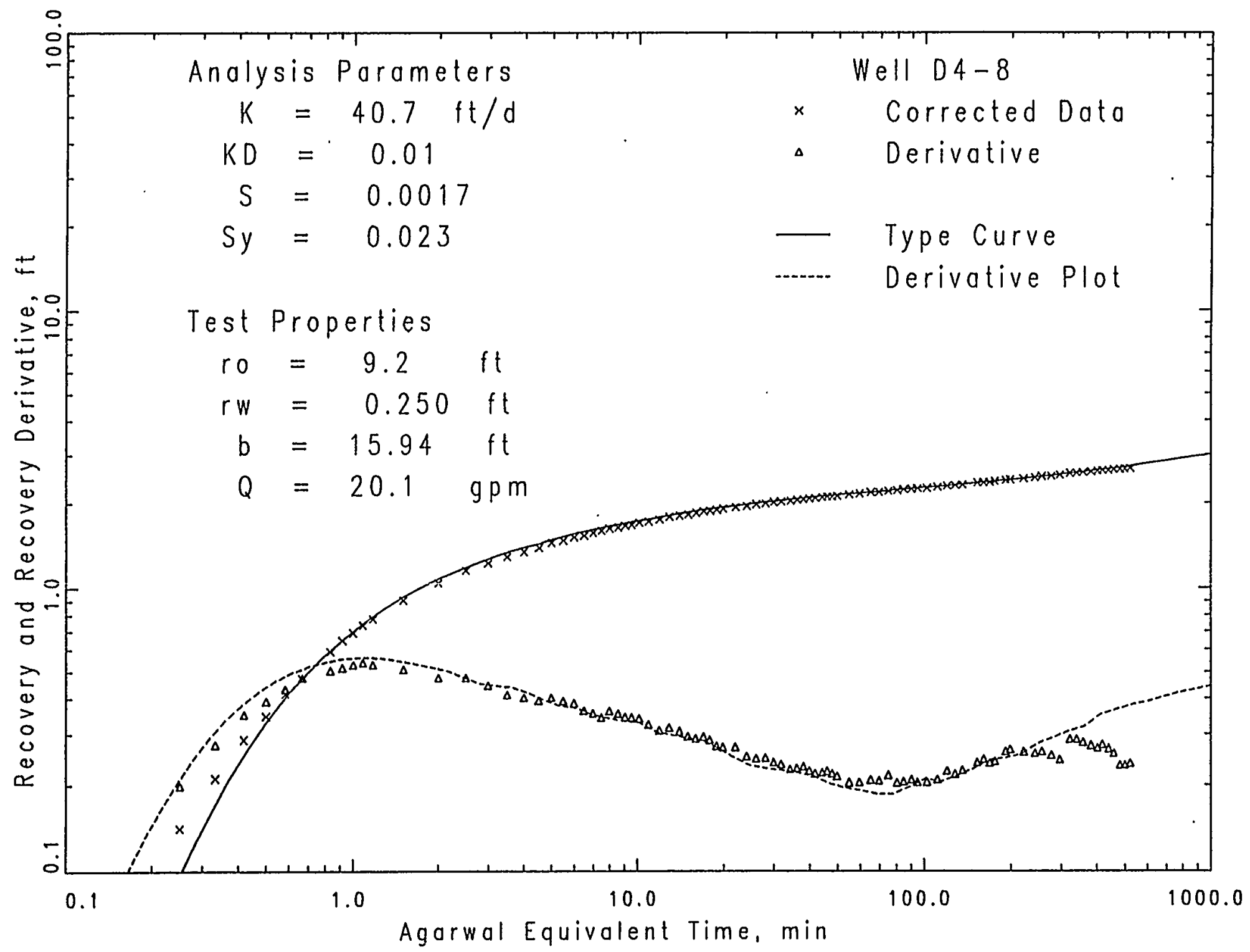

Figure 5.6. Pre-Injection Pumping Test Recovery Analysis Plot for Well D4-8 


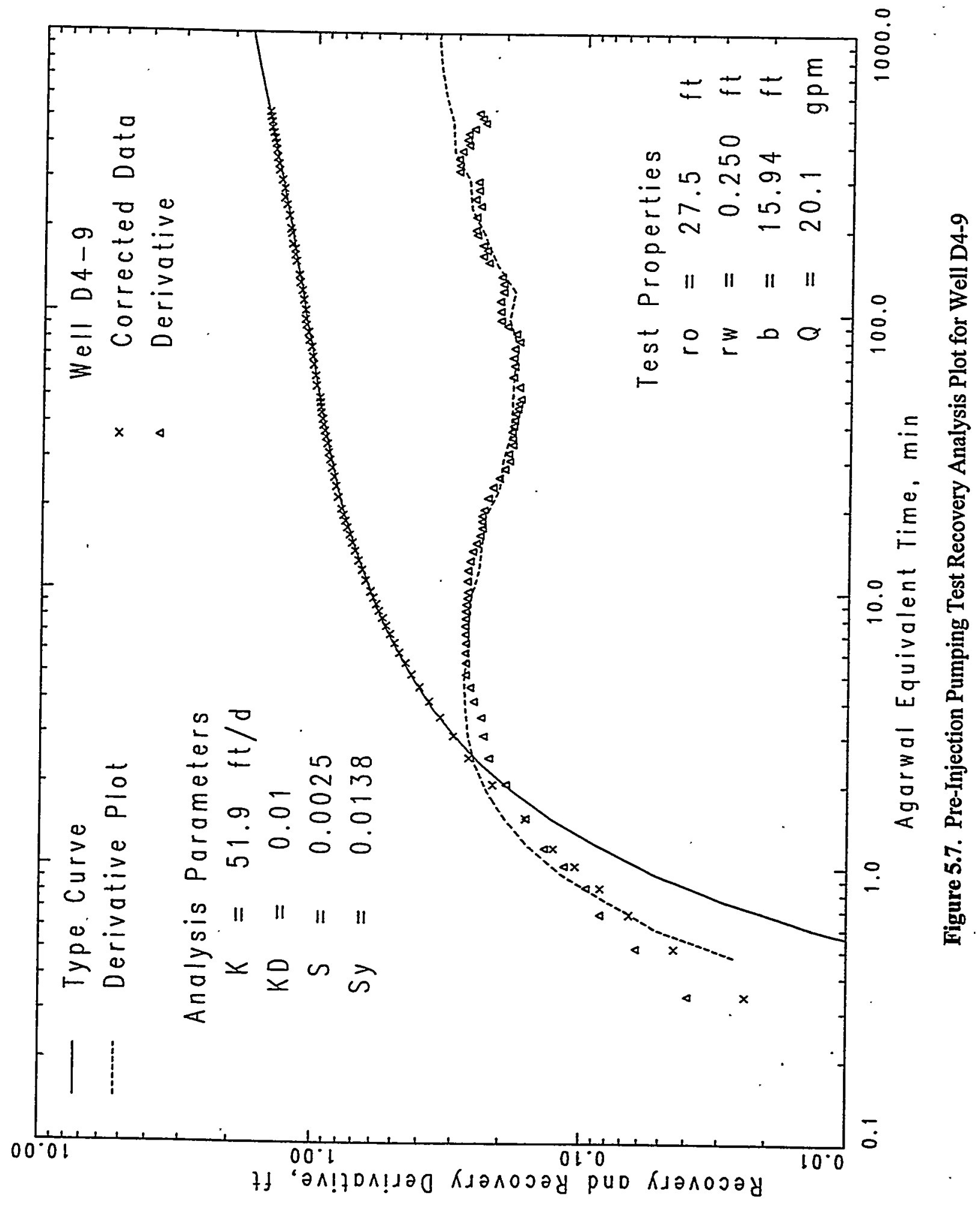

B. 17 


\subsection{Post Injection Test Analysis Plots}

B.18 


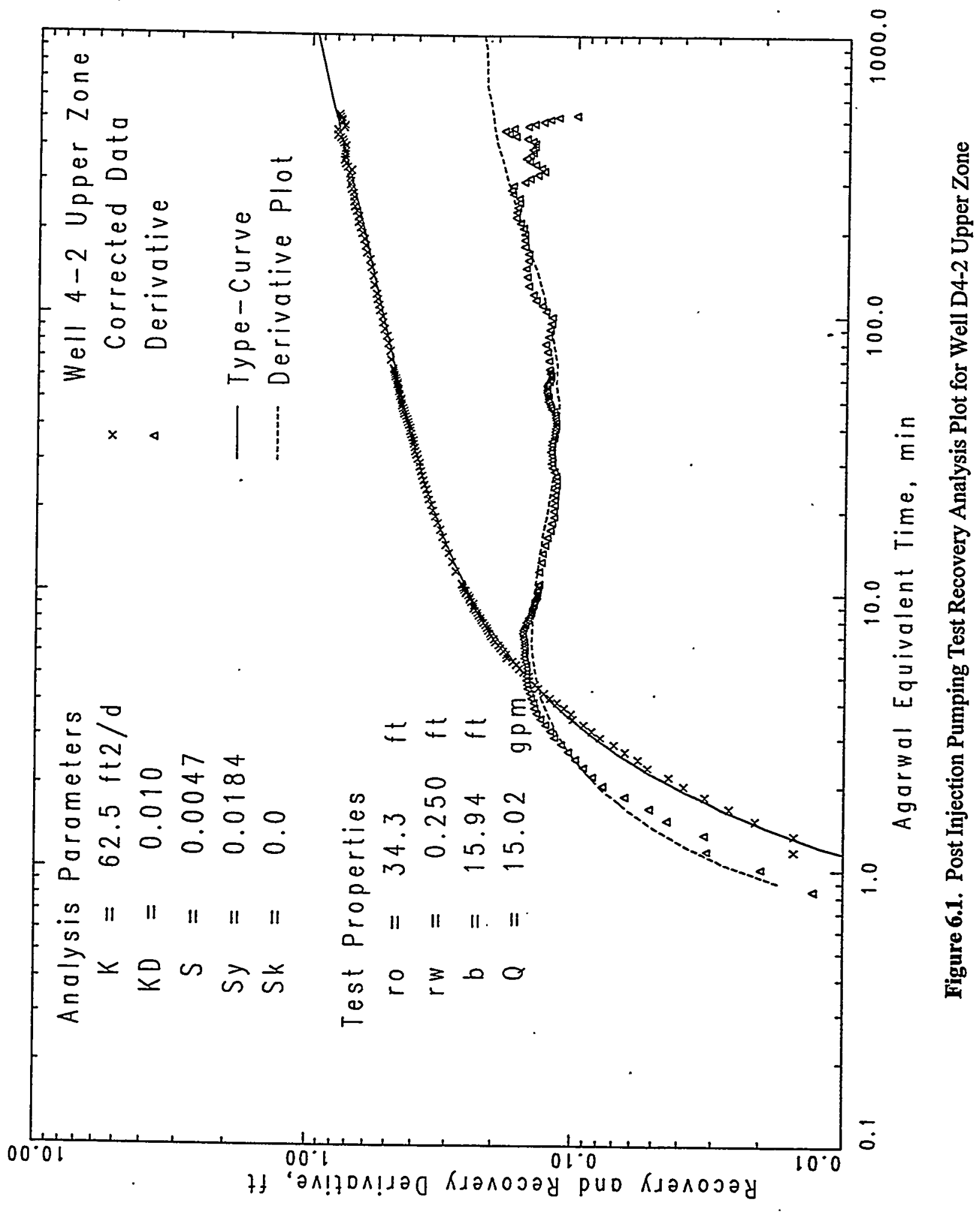




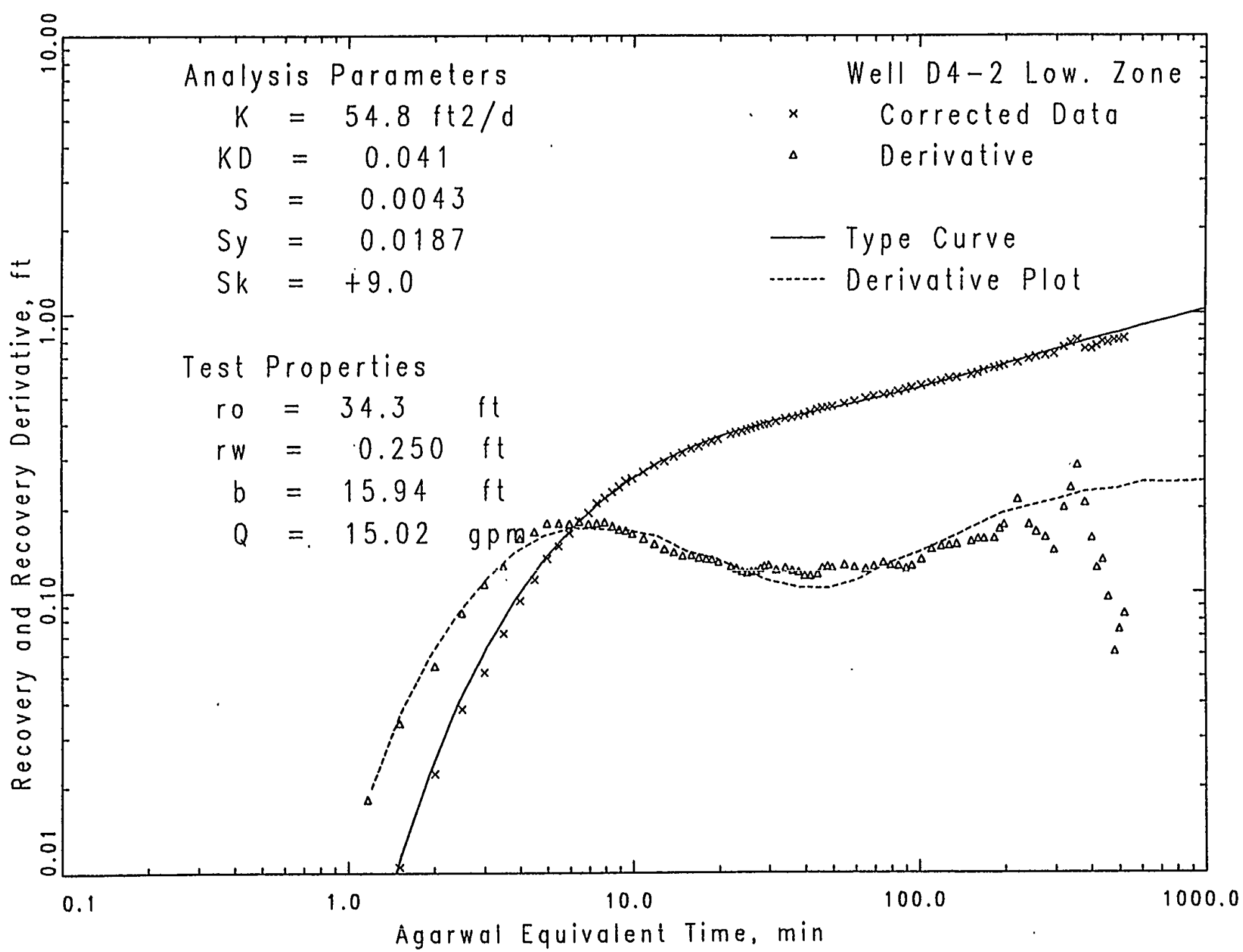

Figure 6.2. Post Injection Pumping Test Recovery Analysis Plot for Well D4-2 Lower Zone 


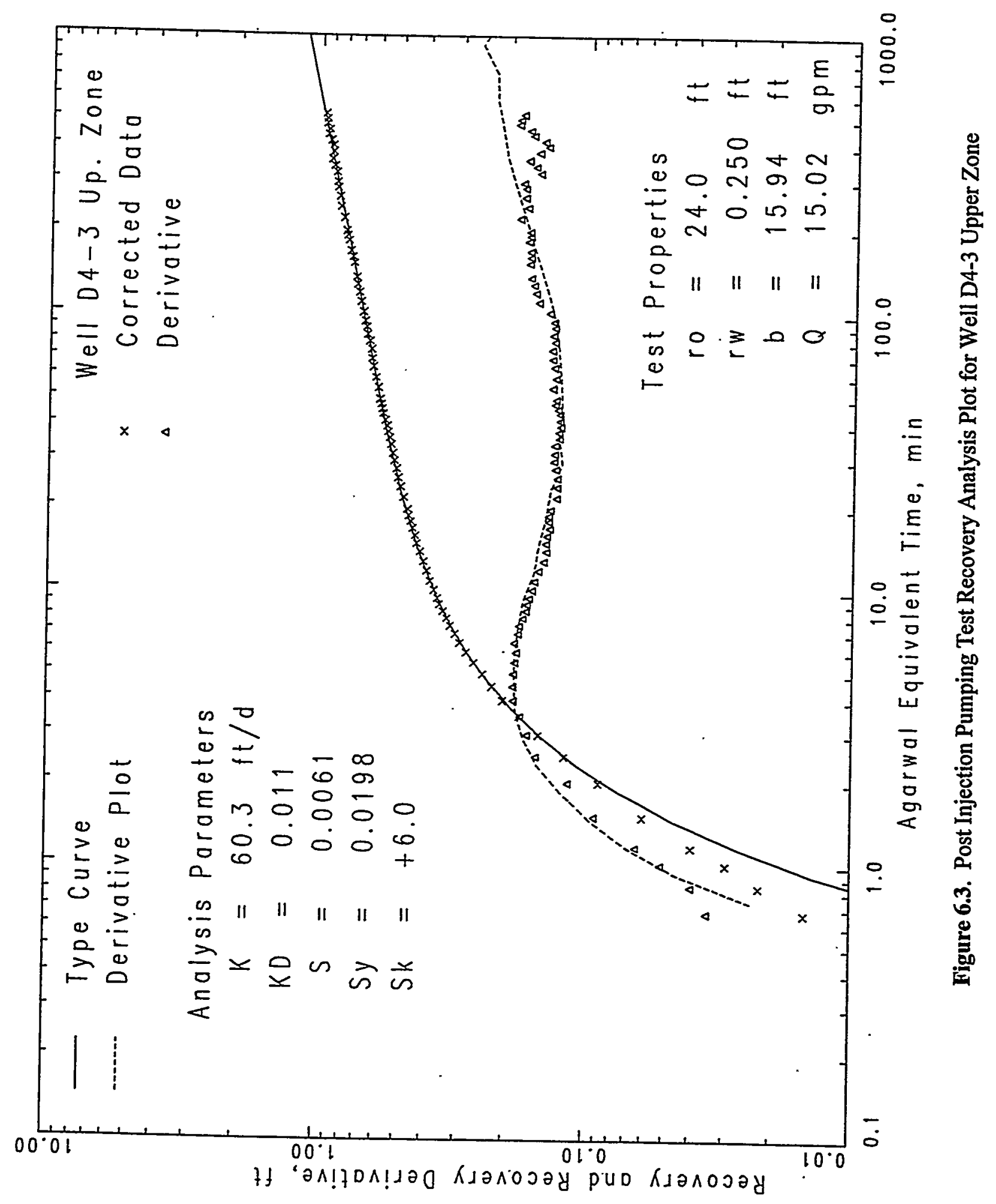




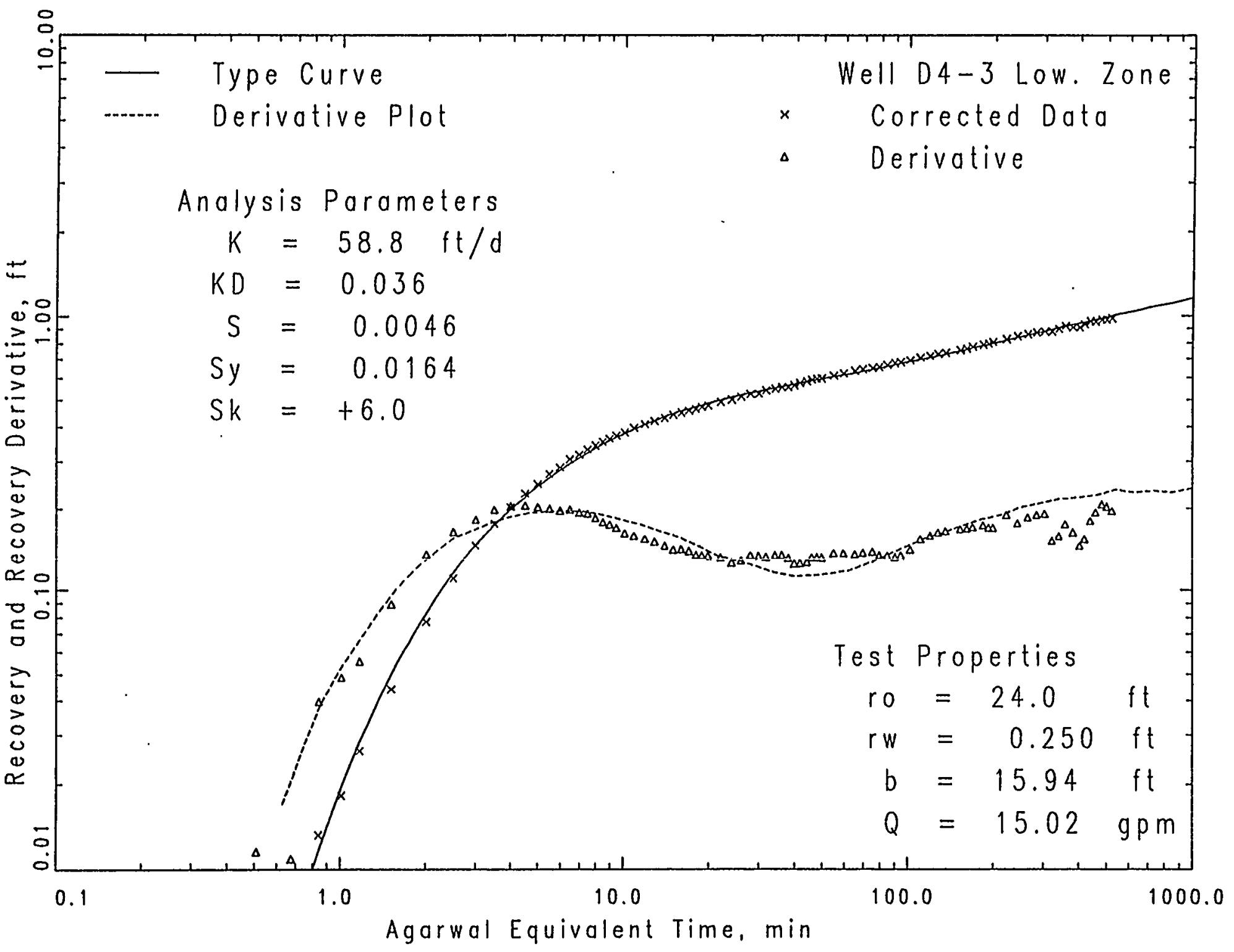

Figure 6.4. Post Injection Pumping Test Recovery Analysis Plot for Well D4-3 Lower Zone 


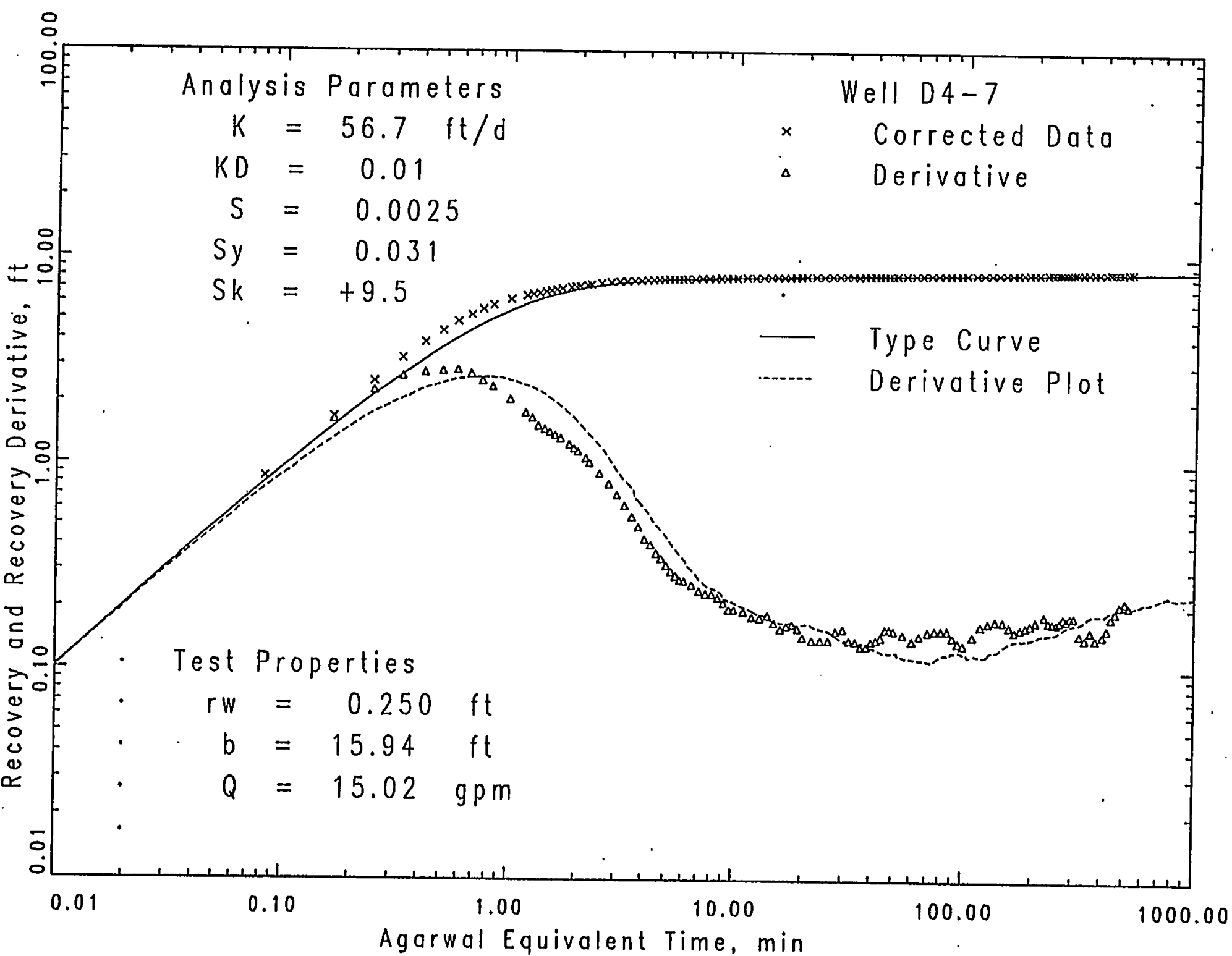

Figure 6.5. Post Injection Pumping Test Recovery Analysis Plot for Well D4-7 (Injection Well) 


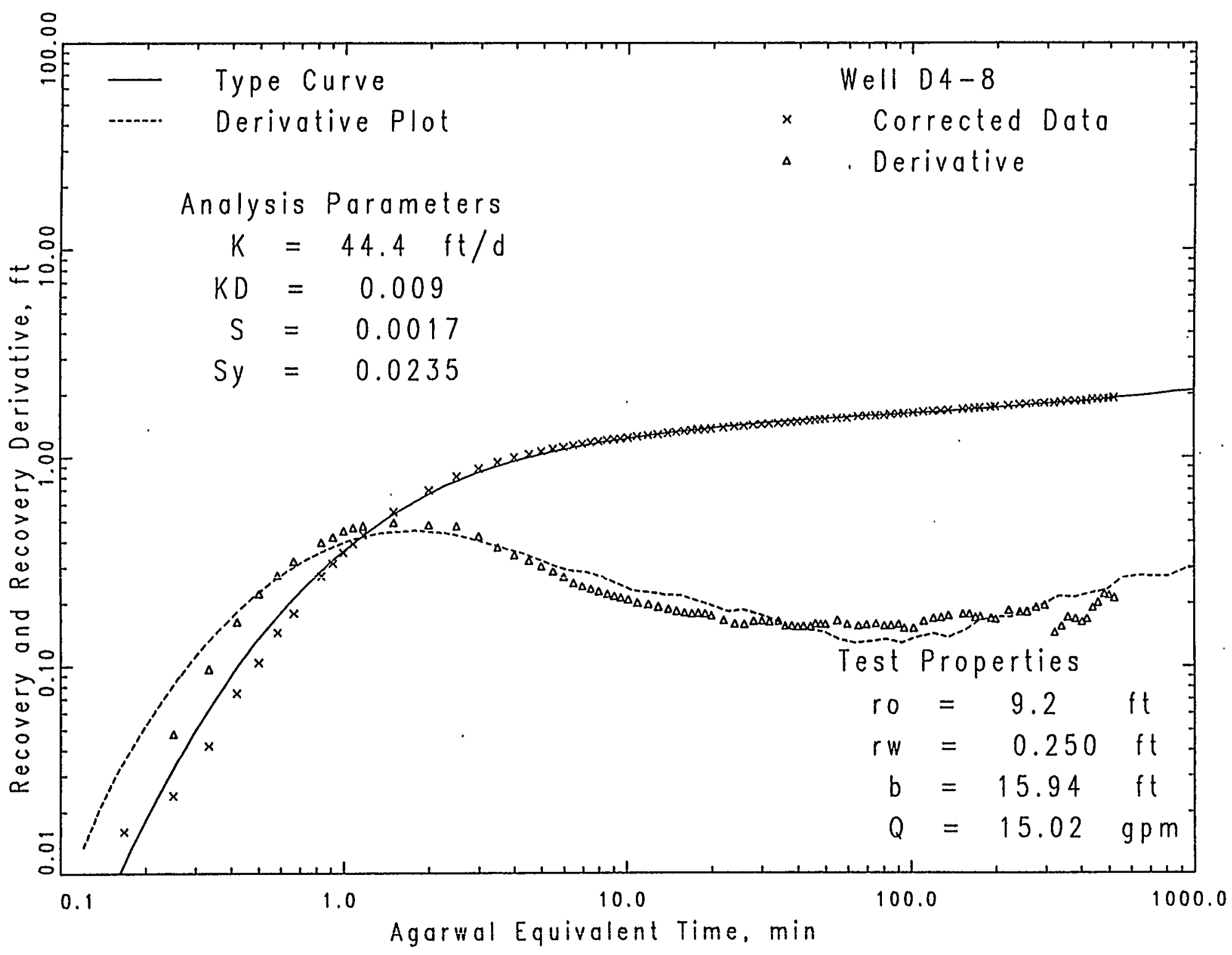

Figure 6.6. Post Injection Pumping Test Recovery Analysis Plot for Well D4-8 


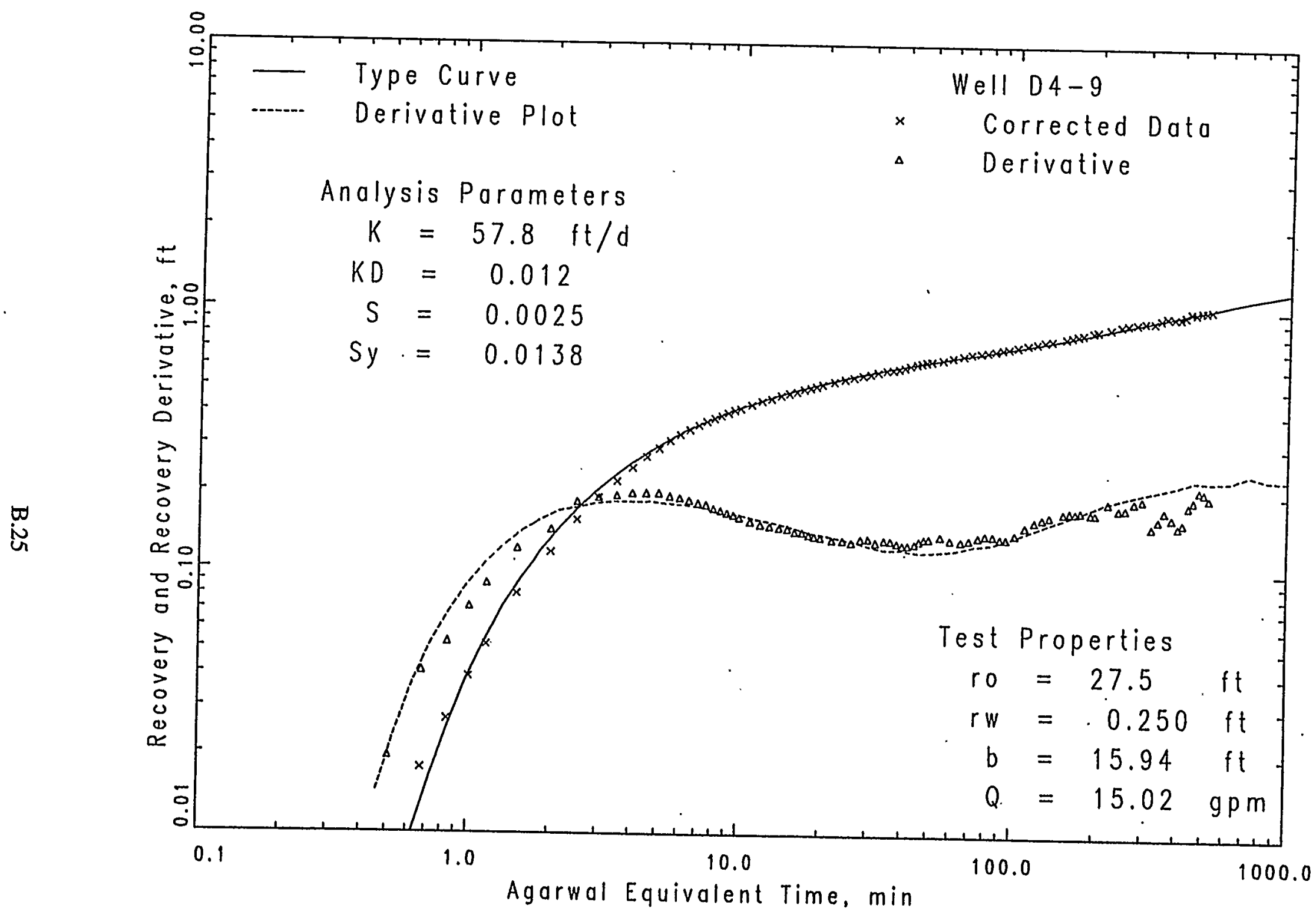

Figure 6.7. Post Injection Pumping Test Recovery Analysis Plot for Well D4-9 


\section{Appendix C}

Columbia River Substrate Porewater Sampling Tube Results 


\begin{tabular}{|c|r|r|r|r|r|}
\hline pH & \multicolumn{7}{c}{ Columbla River Porewater Sampler J0 } & 7/30/98 \\
\hline Depth (ft) & Redox01 & Redox02 & \multicolumn{1}{c|}{ T039 } & Redox03 & \multicolumn{1}{c|}{ Redox04 } \\
\hline 3 & 7.22 & 7.36 & & 7.62 & 7.7 \\
\hline $6^{*}$ & 7.45 & 7.26 & 7.52 & 7.63 & 7.73 \\
\hline 10 & & & 7.67 & & \\
\hline 15 & & & 7.69 & & \\
\hline
\end{tabular}

"Note: Lower Depth of Redox03 is $4.6 \mathrm{ft}$.

Cond.

(us/cm) Columbla Rlver Porewater Sampler ID

Depth (ti) Redox01 Redox02 TD39 Redox03 Redox0

\begin{tabular}{|c|r|r|r|r|r|}
\hline 3 & 376 & 312 & & \multicolumn{1}{c|}{ Redox03 } & Redox04 \\
\hline $6^{*}$ & 434 & 368 & 255 & 461 & 316 \\
\hline 10 & & & 410 & & 326 \\
\hline 15 & & & 436 & & \\
\cline { 4 - 6 } & & & &
\end{tabular}

- Note: Lower Depth of Redox03 is $4.6 \mathrm{ft}$.

\begin{tabular}{|c|c|c|c|c|c|}
\hline \multirow{2}{*}{$\begin{array}{c}\text { DO } \\
(\mathrm{mg} / \mathrm{L}) \\
\text { Depth (ft) }\end{array}$} & \multicolumn{4}{|c|}{ Columbla River Porewater Sampler ID } & \multirow{2}{*}{$\frac{7 / 30 / 98}{\text { Redox04 }}$} \\
\hline & Redox01 & Redox02 & TD39 & Redox03 & \\
\hline 3 & 6.99 & 6.06 & & 6.35 & 4.8 \\
\hline 6* & 7.1 & 4.7 & 7.41 & 6.09 & 5.29 \\
\hline 10 & & & 8.16 & & \\
\hline 15 & & & 8.34 & & \\
\hline
\end{tabular}

-Note: Lower Depth of Redox03 is $4.6 \mathrm{ft}$.

Cr6t

(mq/L) Columbila River Porewater Sampler ID

$7 / 30 / 98$

Depth (ft) Redox01 Redox02 TO39 Redox03

Redox04

\begin{tabular}{|c|r|r|r|r|r|}
\hline 3 & 0.56 & 0.18 & & 0.74 & 0.36 \\
\hline $6^{*}$ & 0.6 & 0.1 & 0.16 & 0.72 & 0.38 \\
\hline 10 & & & 0.56 & & \\
\hline 15 & & & 0.64 & & \\
\hline
\end{tabular}

"Note: Lower Depth of Redox03 is $4.6 \mathrm{ft}$.

\begin{tabular}{|c|c|c|c|c|c|}
\hline $\mathrm{SO}_{4}^{2}$ & Columbia F & iver Porow & r Sample & 10 & $7 / 30 / 98$ \\
\hline Depth (ft) & Redox01 & Redox02 & TD39 & Redox03 & Redox04 \\
\hline 3 & 59.1 & 42.2 & & 72.7 & 41.7 \\
\hline 6 & 66.1 & 52.7 & 28.2 & 72.2 & \\
\hline 10 & & & 63 & & \\
\hline 15 & & & 68.2 & & \\
\hline
\end{tabular}

\section{Cr (ppm) Columbia River Porewater Sampler ID}

$7 / 30 / 98$

\begin{tabular}{llllll} 
Depth (ft) & Redox01 Redox02 & TD39 & Redox03 & Redox04 \\
\hline
\end{tabular}

\begin{tabular}{|c|r|r|r|r|r|}
\hline 3 & 11.4 & 7.68 & & 15.3 & 9.73 \\
\hline 6 & 15.4 & 10.3 & 4.1 & 14.9 & \\
\hline 10 & & & 12.3 & & \\
\hline 15 & & & 14.5 & & \\
\hline
\end{tabular}

\begin{tabular}{|c|c|c|c|c|c|}
\hline $\mathrm{NO}_{3}^{-}$ & Columbia & Iver Poraw & ir Sample & ID & $7 / 30 / 98$ \\
\hline Depth (ft) & Redox01 & Redox02 & TD39 & Redox03 & Redox04 \\
\hline 3 & $\begin{array}{r}27 \\
\end{array}$ & 19.2 & & 35.4 & 19.4 \\
\hline 6 & 36.2 & 21.9 & 11.3 & 34.8 & \\
\hline 10 & & & 30.7 & & \\
\hline 15 & & & 56.3 & & \\
\hline
\end{tabular}

\begin{tabular}{|c|c|c|c|c|c|}
\hline $\mathrm{PO}_{4}{ }^{3}$ & Columbla F & iver Porew & or Sample & ID & $7 / 30 / 98$ \\
\hline Depth (ft) & Redox01 & Redox02 & TD39 & Redox03 & Redox04 \\
\hline \begin{tabular}{|l|}
3 \\
\end{tabular} & $<0.2$ & 0.94 & & 0.62 & $<0.2$ \\
\hline 6 & 1.02 & 0.36 & 1.4 & 1.3 & \\
\hline 10 & & & 0.46 & & \\
\hline 15 & & & $<0.2$ & & \\
\hline
\end{tabular}

F (ppm) Columbla Aiver Porewater Sampler ID

$7 / 30 / 98$ Depth (A) Redox01 Redox02 TD39 Redox03

\begin{tabular}{|c|r|r|r|r|r|}
\hline Depth (At) & Redox01 & Redox02 & \multicolumn{1}{c|}{ TD39 } & Redox03 & Redox04 \\
\hline 3 & 0.34 & 0.31 & & 0.37 & 0.31 \\
\hline 6 & 0.4 & 0.34 & 0.23 & 0.35 & \\
\hline 10 & & & 0.31 & & \\
\hline 15 & & & 0.43 & & \\
\hline
\end{tabular}




\begin{tabular}{|c|c|c|c|c|c|}
\hline pH & \multicolumn{4}{|c|}{ Columbia River Porewater Sampler ID } & $5 / 7 / 98$ \\
\hline Depth $(t)$ & Redox01 & Redox02 & TD39 & Redox03 & Redox04 \\
\hline 3 & 7.31 & 7.55 & & 7.96 & 7.9 \\
\hline $6=$ & 7.46 & 7.36 & 7.65 & 7.95 & 7.84 \\
\hline 10 & & & 7.66 & & \\
\hline 15 & & & 7.63 & & \\
\hline
\end{tabular}

Note: Lower Depth of Redox03 is $4.6 \mathrm{ft}$

\begin{tabular}{|c|c|c|c|c|c|}
\hline \multirow{2}{*}{$\begin{array}{c}\text { Cond. } \\
\text { (us/cm) } \\
\text { Depth (ft) }\end{array}$} & \multicolumn{4}{|c|}{ Columbia River Porewater Sampler ID } & \multirow{2}{*}{$\frac{5 / 7 / 98}{\text { Redox04 }}$} \\
\hline & Redox01 & Redox02 & TD39 & Redox03 & \\
\hline 3 & 395 & 185.4 & & 160.4 & 172.3 \\
\hline $6 \cdot$ & 394 & 328 & 179.3 & 155.5 & 373 \\
\hline 10 & & & 509 & & \\
\hline 15 & & & 592 & & \\
\hline
\end{tabular}

Note: Lower Depth of Redox03 is $4.6 \mathrm{ft}$

\begin{tabular}{|c|c|c|c|c|c|}
\hline $\begin{array}{c}\text { DO } \\
(\mathrm{mg} / \mathrm{l})\end{array}$ & \multicolumn{4}{|c|}{ Columbla River Porewater Sampler ID } & \multirow{2}{*}{$\frac{5 / 7 / 98}{\text { Aedox04 }}$} \\
\hline Depth (ft) & Redox01 & Redox02 & TD39 & Redox03 & \\
\hline 3 & 7.6 & 9.35 & & 9.06 & 4.3 \\
\hline $6^{\circ}$ & 8.1 & 5.9 & 12.8 & 9.79 & 5.5 \\
\hline 10 & & & 10.3 & & \\
\hline 15 & & & 10.27 & & \\
\hline \multicolumn{6}{|c|}{ - Note: Lower Depth of Redox03 is $4.6 \mathrm{ft}$} \\
\hline $\begin{array}{c}\text { Cr6t } \\
(\mathrm{mg} / \mathrm{l})\end{array}$ & \multicolumn{4}{|c|}{ Columbla River Porewater Sampler ID } & $5 / 7 / 98$ \\
\hline Depth (ft) & Redox01 & Redox02 & TD39 & Redox03 & Redox04 \\
\hline 3 & 0.56 & 0.04 & & $\mathbf{0}$ & 0.04 \\
\hline $6^{*}$ & 0.6 & 0.08 & 0.02 & 0 & 0.6 \\
\hline 10 & & & 0.66 & & \\
\hline 15 & & & 0.84 & & \\
\hline
\end{tabular}

-Note: Lower Depth of Redox03 is $4.6 \mathrm{ft}$

\begin{tabular}{|c|c|c|c|c|c|}
\hline \multirow{2}{*}{$\begin{array}{c}\mathrm{SO}_{4}^{2-} \\
\text { Depth (ft) }\end{array}$} & \multicolumn{5}{|c|}{ Columbia River Porewater Sampler ID } \\
\hline & Redox01 & Redox02 & TD39 & Redox03 & Redox04 \\
\hline 3 & 61.9 & 17.3 & & 7 & 11.1 \\
\hline 6 & 61.8 & 39.9 & 9.41 & 8.5 & 53.6 \\
\hline 10 & & & 70.3 & & \\
\hline 15 & & & 100 & & \\
\hline
\end{tabular}

(:1* (ppm) Coiumbla River Porewater Sampler ID

$5 / 7 / 98$

\begin{tabular}{l|lllll} 
Depth (ft) & Redox01 Redox02 & TD39 & Redox03 & Redox04 \\
\hline
\end{tabular}

\begin{tabular}{|r|r|r|r|r|r|}
\hline 3 & 12.7 & 2.3 & & 2.87 & 3.2 \\
\hline 6 & 13.2 & 8.51 & 3.1 & 0.92 & 13.7 \\
\hline 10 & & & 13 & & \\
\hline 15 & & & 18.3 & & \\
\hline
\end{tabular}

\begin{tabular}{|c|c|c|c|c|c|}
\hline $\mathrm{NO}_{3}^{-}$ & Columbla $\mathrm{F}$ & Iver Porew & er Sample & ID & $5 / 7 / 98$ \\
\hline Depth (ft) & Redox01 & Redo $\times 02$ & TD39 & Redox03 & Redox04 \\
\hline 3 & 36.5 & 0.56 & & $<2$ & 2.6 \\
\hline 6 & 36.6 & 19 & 2.35 & 0.85 & 30.9 \\
\hline 10 & & & 40.3 & & \\
\hline 15 & & & 57 & & \\
\hline
\end{tabular}

\begin{tabular}{|c|c|c|c|c|c|}
\hline $\mathrm{PO}_{4}{ }^{3-}$ & Columbla F & Iver Parew & er Sample: & ID & $5 / 7 / 98$ \\
\hline Depth (ft) & Redox01 & Redox02 & TD39 & Redox03 & Redox04 \\
\hline 3 & $<2$ & 0.22 & & $<2$ & $<2$ \\
\hline 6 & $<2$ & $<2$ & $<2$ & 0.26 & $<2$ \\
\hline 10 & & & 2.1 & & \\
\hline 15 & & & $<2$ & & \\
\hline
\end{tabular}

\begin{tabular}{|c|r|r|r|r|r|}
\hline F- (ppm) Columbla Rlver Porewater Sampler ID & 5/7/98 \\
\hline Depth (ft) & Redox01 & Redox02 & TD39 & Redox03 & Redox04 \\
\hline 3 & $<2$ & 0.37 & & 2.62 & $<2$ \\
\hline 6 & 2.4 & $<2$ & $<2$ & 0.45 & $<2$ \\
\hline 10 & & & $<2$ & & \\
\hline 15 & & & $<2$ & & \\
\hline
\end{tabular}




\begin{tabular}{|c|r|r|r|r|r|}
\hline pH Columbia River Porewater Sampler ID & 3/19/98 \\
\hline Depth (ft) & Redox01 & \multicolumn{1}{c|}{ Redox02 } & \multicolumn{1}{c|}{ TD39 } & Redox03 & Redox04 \\
\hline 3 & 7.35 & 7.53 & & 7.78 & 7.75 \\
\hline 6 & 7.59 & 7.4 & 7.68 & 7.8 & 8.02 \\
\hline 10 & & & 7.73 & & \\
\hline 15 & & & 7.73 & & \\
\hline
\end{tabular}

\begin{tabular}{|c|c|c|c|c|c|}
\hline $\begin{array}{c}\text { Cond. } \\
(\mu \mathrm{s} / \mathrm{cm})\end{array}$ & Columbia & iver Porew & r Sample & ID & $3 / 19 / 98$ \\
\hline Depth (ft) & Redox01 & Redox02 & TD39 & Redox03 & Redox04 \\
\hline 3 & 372 & 284 & & 507 & 360 \\
\hline 6 & 392 & 318 & 358 & 509 & 367 \\
\hline 10 & & & 520 & & \\
\hline 15 & & & 529 & & \\
\hline
\end{tabular}

\begin{tabular}{|c|c|c|c|c|c|}
\hline $\begin{array}{c}\text { DO } \\
(\mathrm{mg} / \mathrm{L})\end{array}$ & Columbia F & iver Porew & Sample & ID & $3 / 19 / 98$ \\
\hline Depth (ft) & Redox01 & Redox02 & TD39 & Redox03 & Redox04 \\
\hline 3 & 5.12 & 7.9 & & 8.7 & 7.93 \\
\hline 6 & 7.58 & 3.33 & 10.64 & 7.9 & 3.9 \\
\hline 10 & & & 9.5 & & \\
\hline 15 & & & 10.4 & & \\
\hline
\end{tabular}

\begin{tabular}{|c|r|r|r|r|r|}
\hline $\begin{array}{c}\text { Cr6t } \\
(\mathrm{mg} / \mathrm{L})\end{array}$ & \multicolumn{6}{c|}{ Columbia River Porewater Sampler ID } & 3/19/98 \\
\hline Depth (ft) & Redox01 & Redox02 & \multicolumn{1}{c|}{ TD39 } & Redox03 & Redox04 \\
\hline 3 & 0.52 & 0.2 & & 0.88 & 0.56 \\
\hline 6 & 0.58 & 0.09 & 0.42 & 0.88 & 0.56 \\
\hline 10 & & & 0.82 & & \\
\hline 15 & & & 0.82 & & \\
\hline
\end{tabular}




\begin{tabular}{|c|c|c|c|c|c|}
\hline pH & \multicolumn{4}{|c|}{ Columbia River Porewater Sampler ID } & $3 / 12 / 98$ \\
\hline Depth (ft) & Redox01 & Redox02 & TD39 & Redox03 & Redox04 \\
\hline 3 & 7.43 & 7.64 & & & \\
\hline 6 & 7.58 & 7.5 & & & \\
\hline 10 & & & & & \\
\hline 15 & & & & & \\
\hline
\end{tabular}

\begin{tabular}{|c|c|c|c|c|c|}
\hline $\begin{array}{c}\text { Cond. } \\
\text { (us/cm) }\end{array}$ & Columbia R & iver Porew & r Sam & 10 & $3 / 12 / 98$ \\
\hline Depth (ft) & Redox01 & Redox02 & TD39 & Redox03 & Redox04 \\
\hline 3 & 359 & 224 & & & \\
\hline 6 & 378 & 307 & & & \\
\hline 10 & & & & & \\
\hline 15 & & & & & \\
\hline
\end{tabular}

\begin{tabular}{|c|c|c|c|c|c|}
\hline $\begin{array}{c}\mathrm{DO} \\
(\mathrm{mg} / \mathrm{L})\end{array}$ & \multicolumn{4}{|c|}{ Columbia River Porewater Sampler ID } & $3 / 12 / 98$ \\
\hline Depth (ft) & Redox01 & Redox02 & TD39 & Redox03 & Redox04 \\
\hline 3 & 6.82 & 9.5 & & & \\
\hline 6 & 6.95 & 2.35 & & & \\
\hline 10 & & & & & \\
\hline 15 & & & & & \\
\hline
\end{tabular}

\begin{tabular}{|c|c|c|c|c|c|}
\hline $\begin{array}{c}\text { Cr6+ } \\
(\mathrm{mg} / \mathrm{L})\end{array}$ & Columbia F & iver Porew & Samp & ID & $3 / 12 / 98$ \\
\hline Depth (ft) & Redox01 & Redox02 & TD39 & Redox03 & Redox04 \\
\hline 3 & 0.5 & 0.11 & & & \\
\hline 6 & 0.56 & 0.09 & & & \\
\hline 10 & & & & & \\
\hline 15 & & & & & \\
\hline
\end{tabular}




\begin{tabular}{|c|c|c|c|c|c|}
\hline $\begin{array}{c}\text { Cond. } \\
(\mu s / c m)\end{array}$ & \multicolumn{4}{|c|}{ Columbia River Porewater Sampler ID } & \multirow{2}{*}{$\begin{array}{l}12-10-97 \\
12-11-97 \\
\text { Redox04 }\end{array}$} \\
\hline Depth (ft) & Redox01 & Redox02 & TD39 & Redox03 & \\
\hline 3 & 305.8 & 161.1 & & 148.8 & 221.6 \\
\hline $6^{*}$ & & & & & \\
\hline 10 & & & & & \\
\hline 15 & & & & & \\
\hline
\end{tabular}

"Note: Cond. Is from 12-10-97, Cr6+ is from 12-11-97

\begin{tabular}{|c|c|c|c|c|c|}
\hline $\begin{array}{c}\text { Cr6+ } \\
\text { (mg/L) }\end{array}$ & Columbia F & iver Porew & r Sam & IID & $\begin{array}{l}12-10-97 \\
12-11-97\end{array}$ \\
\hline Depth (ft) & Redox01 & Redox02 & TD39 & Redox03 & Redox04 \\
\hline 3 & 0.356 & 0.039 & & 0.031 & 0.148 \\
\hline 6 & & & & & \\
\hline 10 & & & & & \\
\hline 15 & & & & & \\
\hline
\end{tabular}

"Note: Cond. Is from 12-10-97, Cr6+ is from 12-11-97 


\begin{tabular}{|c|c|c|c|c|c|}
\hline $\begin{array}{c}\text { Cond. } \\
\text { (us/cm) }\end{array}$ & Columbia & iver Porev & er Samp & ID & $\begin{array}{l}11-3-97 \\
11-4-97 \\
\end{array}$ \\
\hline Depth (ft) & Redox01 & Redox02 & TD39 & Redox03 & Redox04 \\
\hline 3 & 369 & & & & 340 \\
\hline 6 & 330 & & & & 350.1 \\
\hline 10 & & & & & \\
\hline 15 & & & & & \\
\hline
\end{tabular}

*Note: Redox01 samples taken 11-3-97

*Note: Redox04 samples taken 11-4-97

\begin{tabular}{|c|c|c|c|c|c|}
\hline $\begin{array}{c}\text { Cr6+ } \\
(\mathrm{mg} / \mathrm{L})\end{array}$ & Columbia & iver Porev & er Samp & & $\begin{array}{l}11-3-97 \\
11-4-97 \\
\end{array}$ \\
\hline Depth (ft) & Redox01 & Redox02 & TD39 & Redox03 & Redox04 \\
\hline 3 & 0.432 & & & & 0.378 \\
\hline 6 & 0.228 & & & & 0.411 \\
\hline 10 & & & & & \\
\hline 15 & & & & & \\
\hline
\end{tabular}

*Note: Redox01 samples taken 11-3-97

*Note: Redox04 samples taken 11-4-97 


\section{Appendix D}

\section{Bromide Tracer Test Breakthrough Curves}




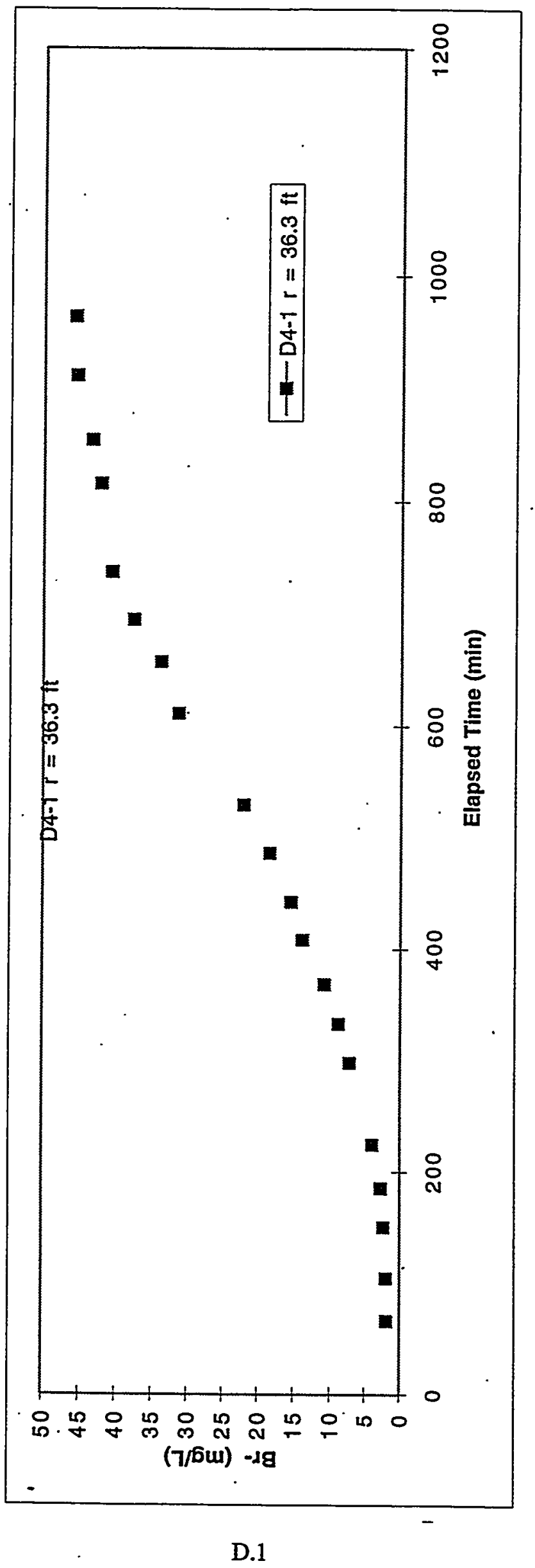




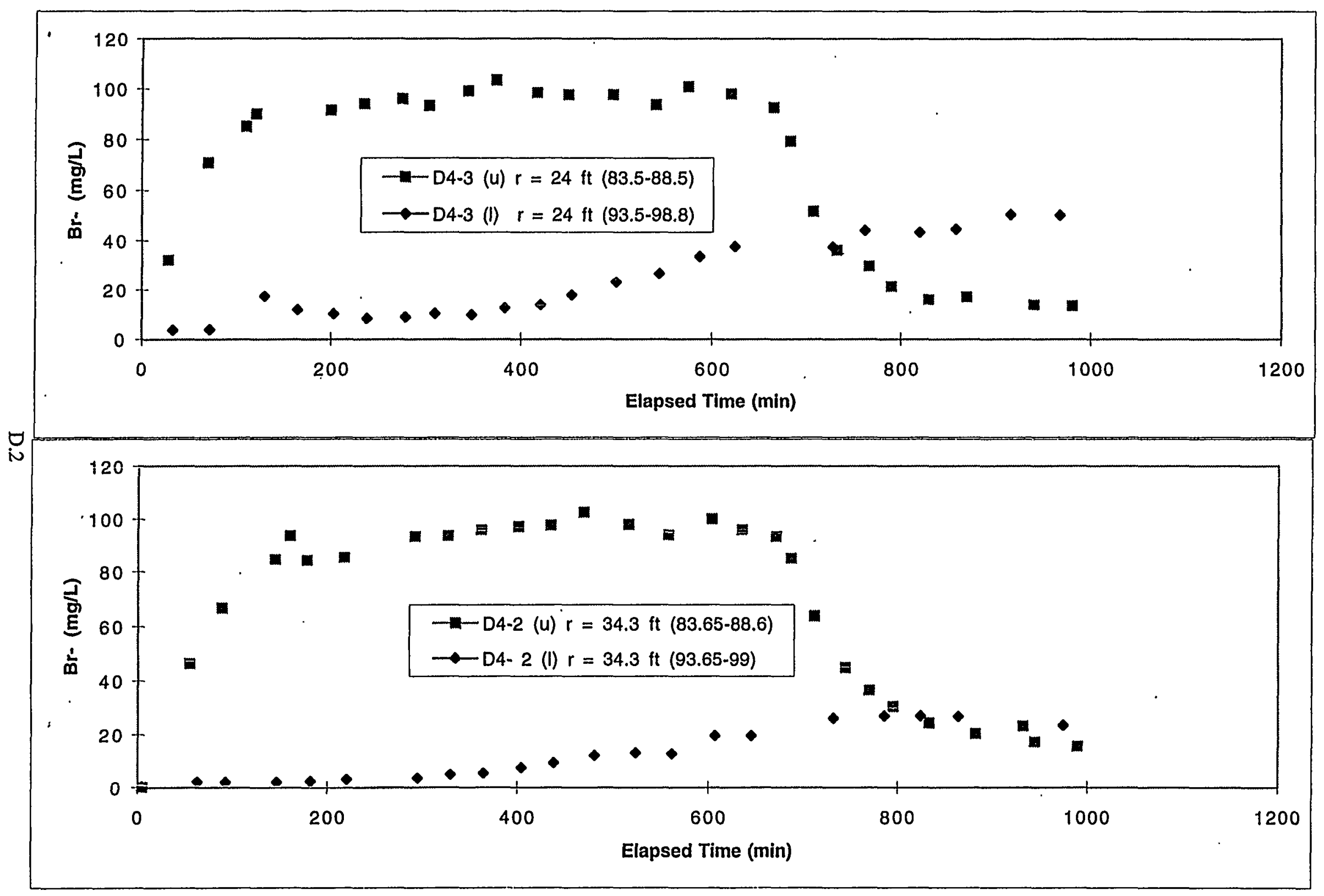




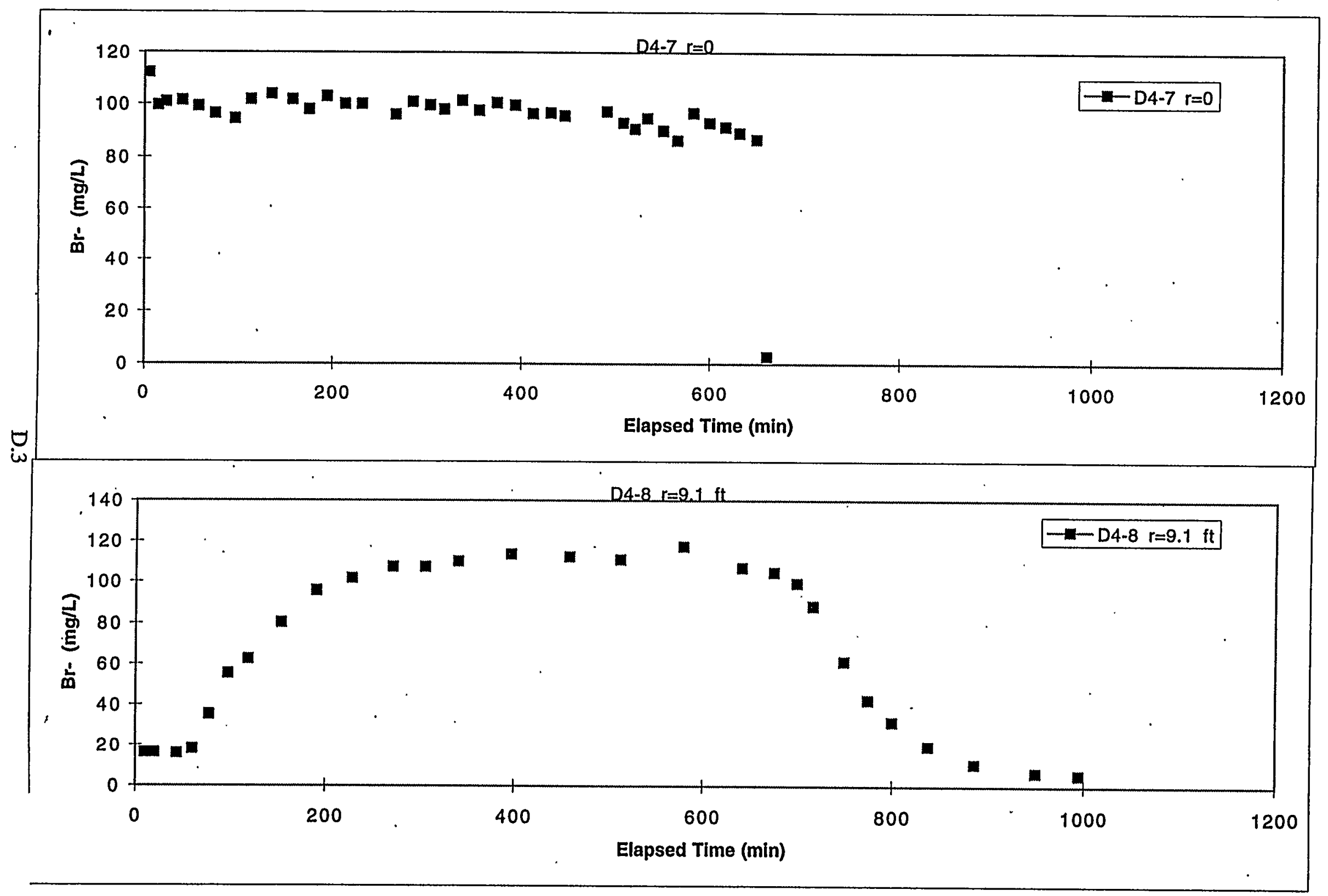




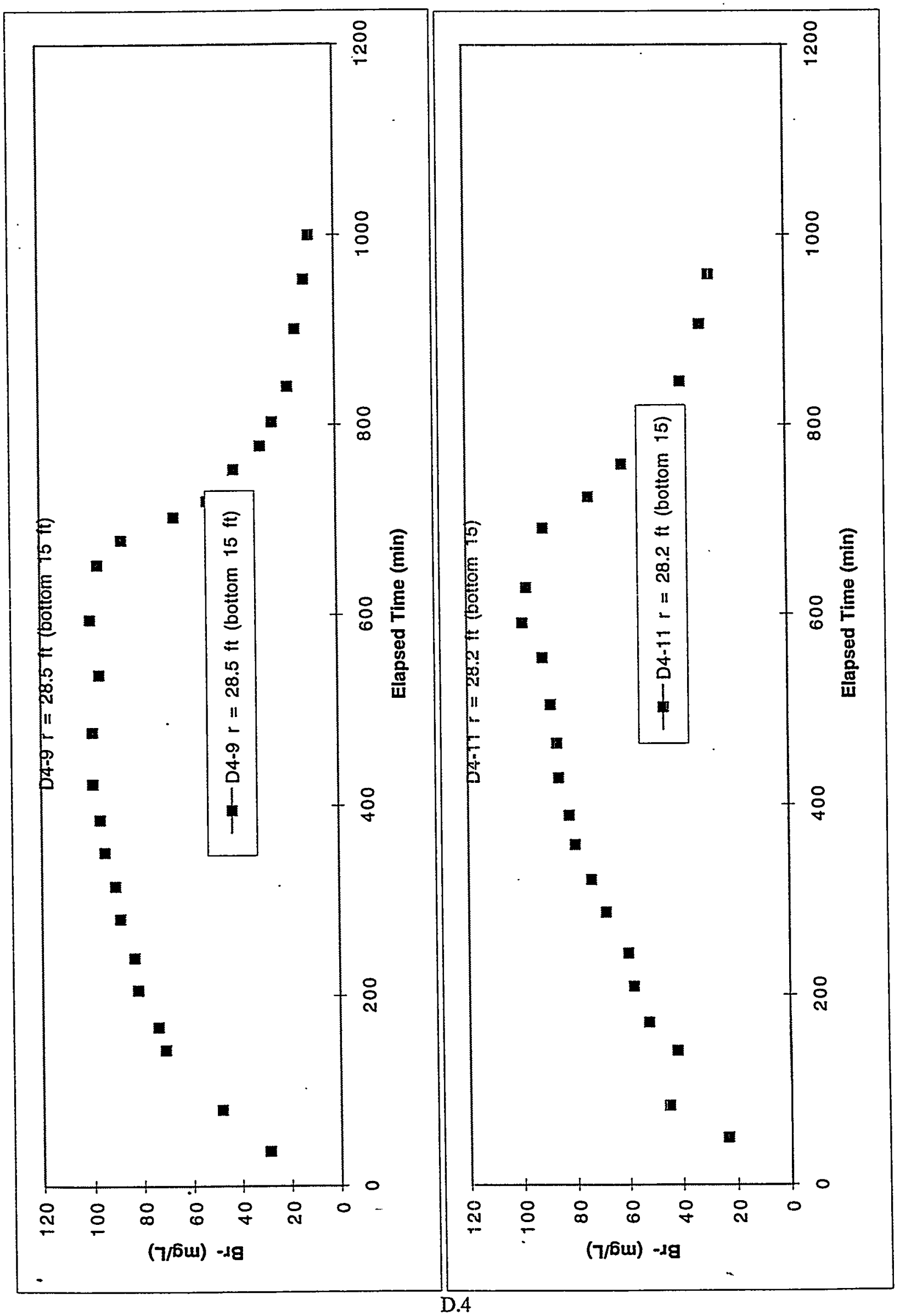




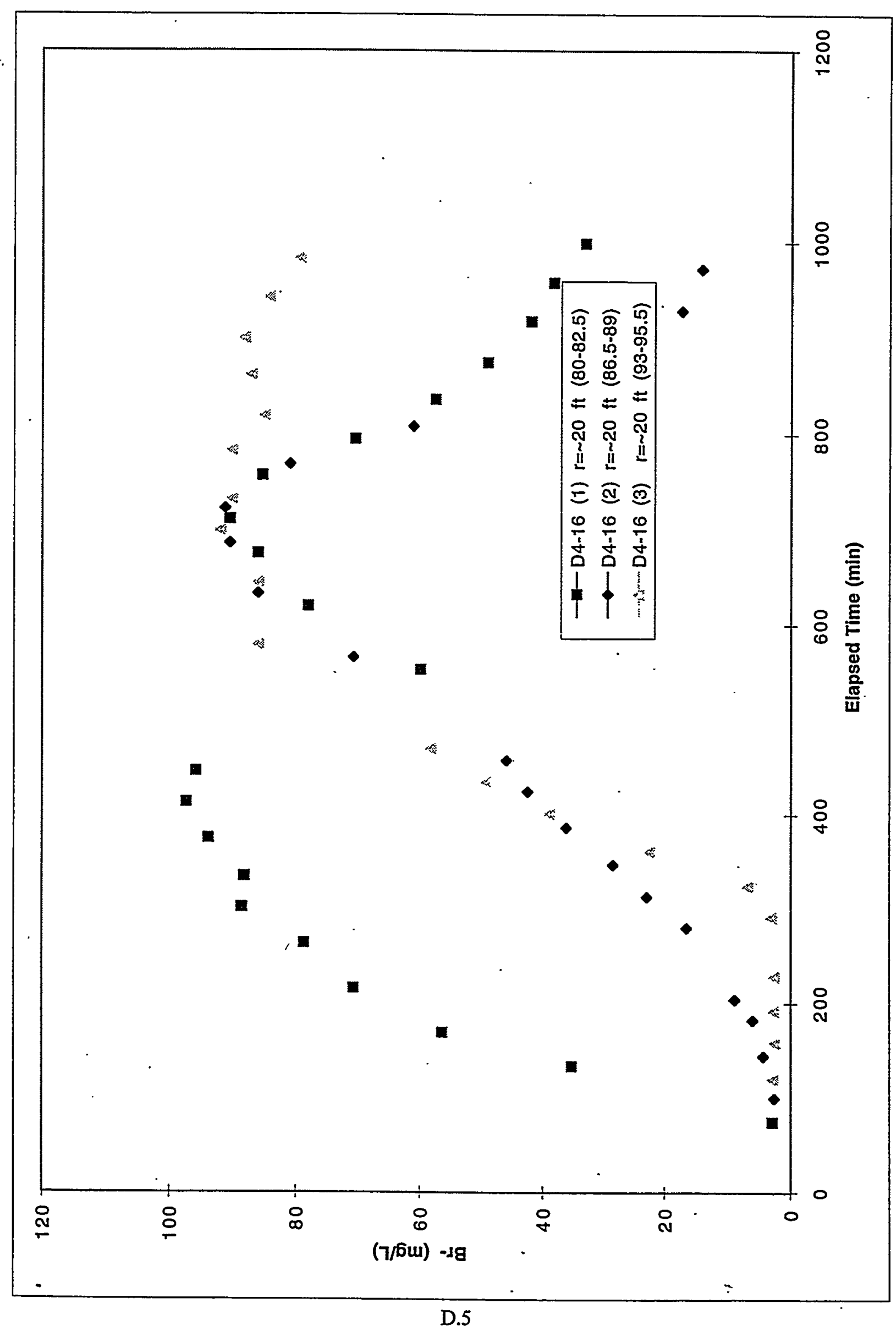


Appendix E

D4-7 Dithionite Injection/Withdrawal Test Breakthrough Curves 


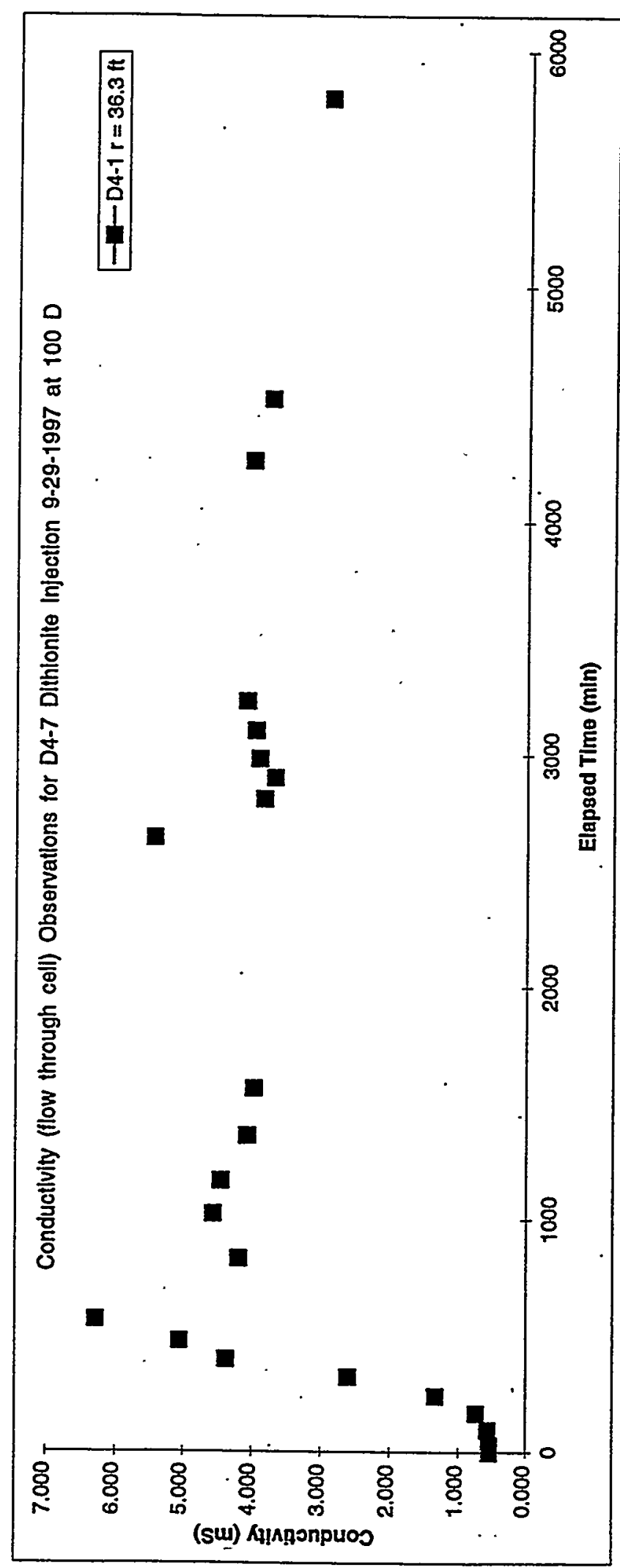

E.1 


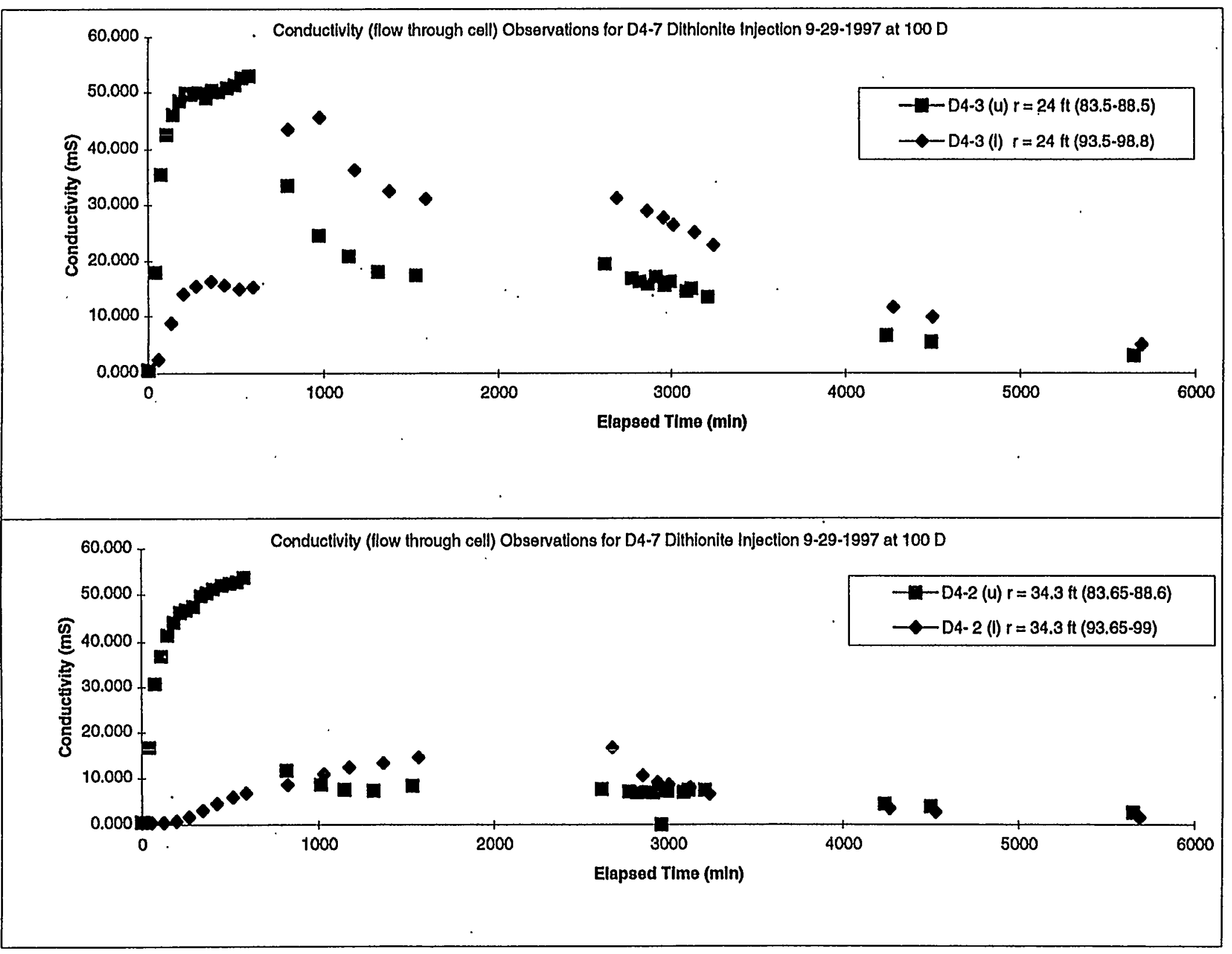




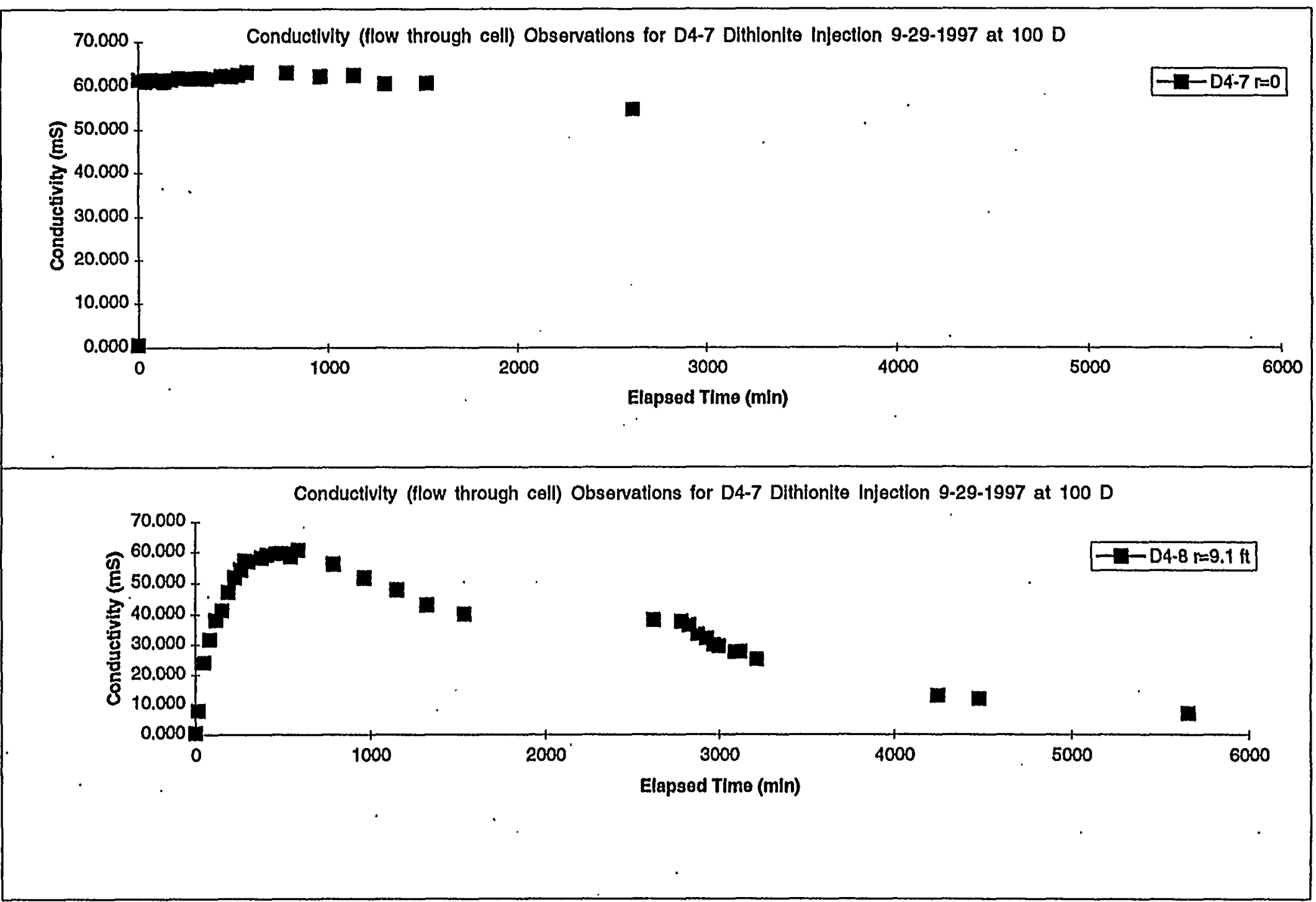




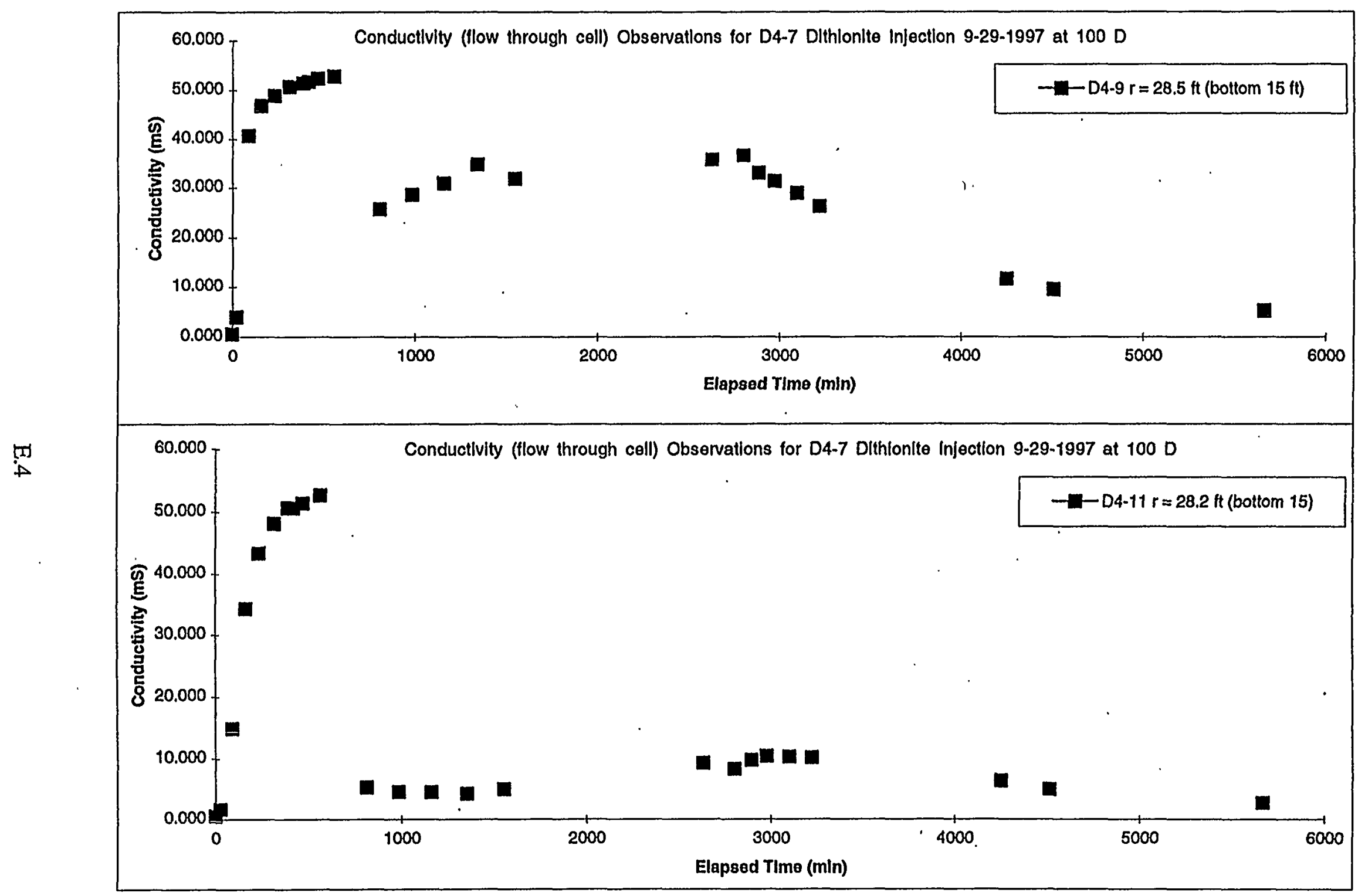




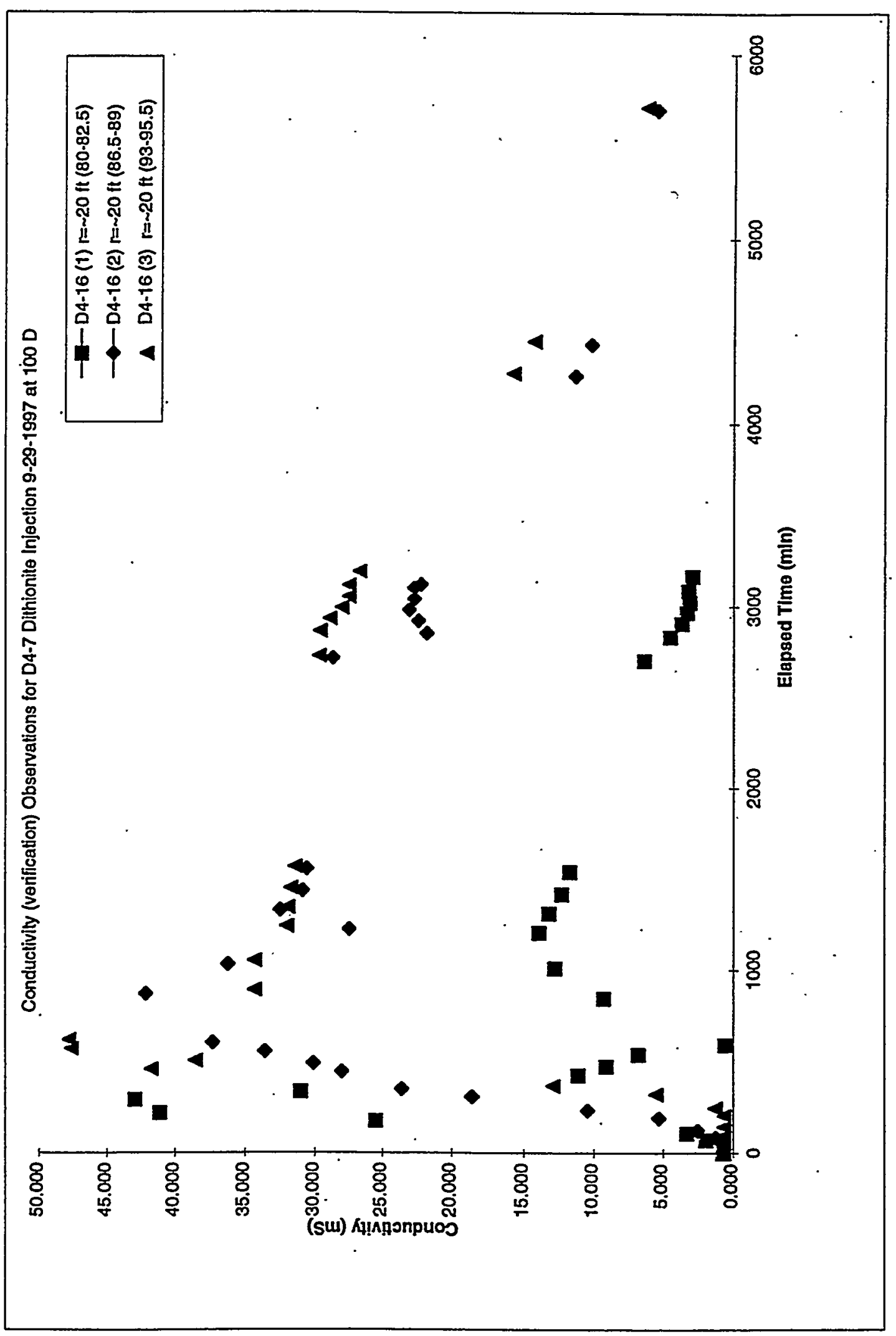

E.5 


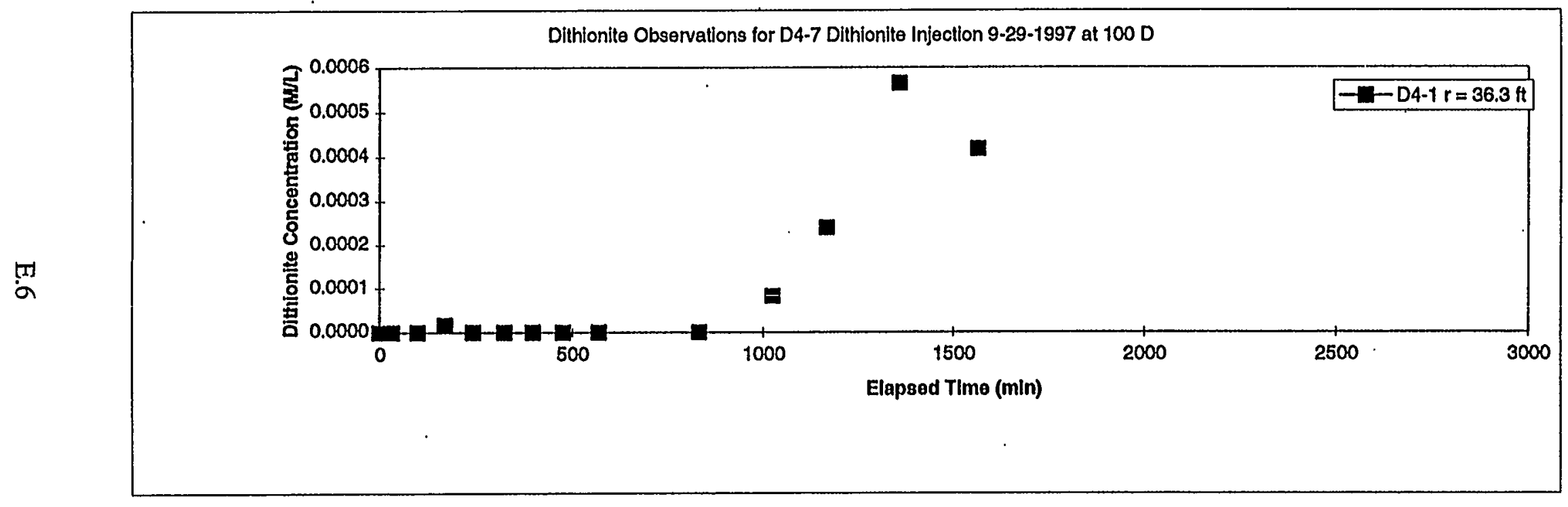




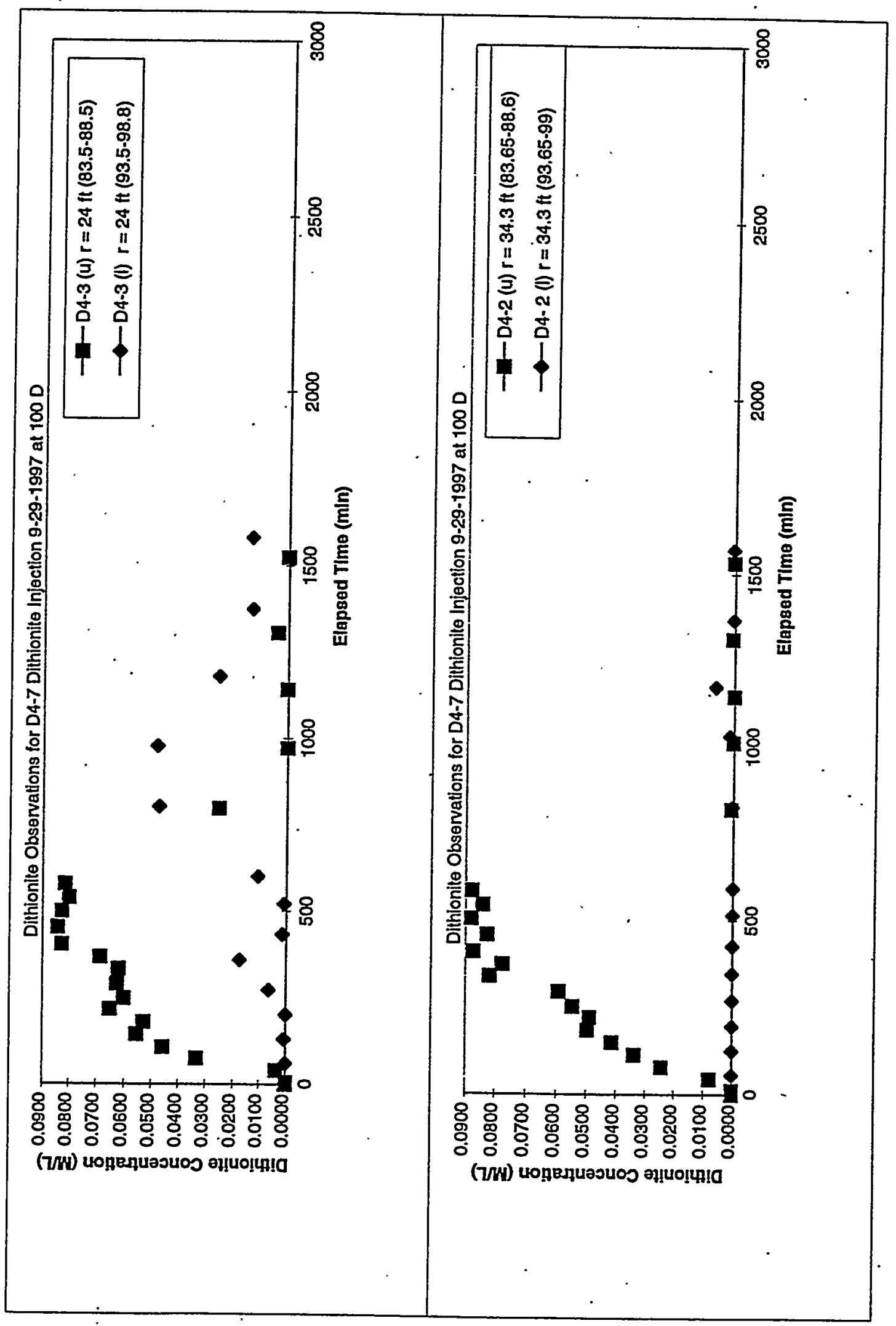




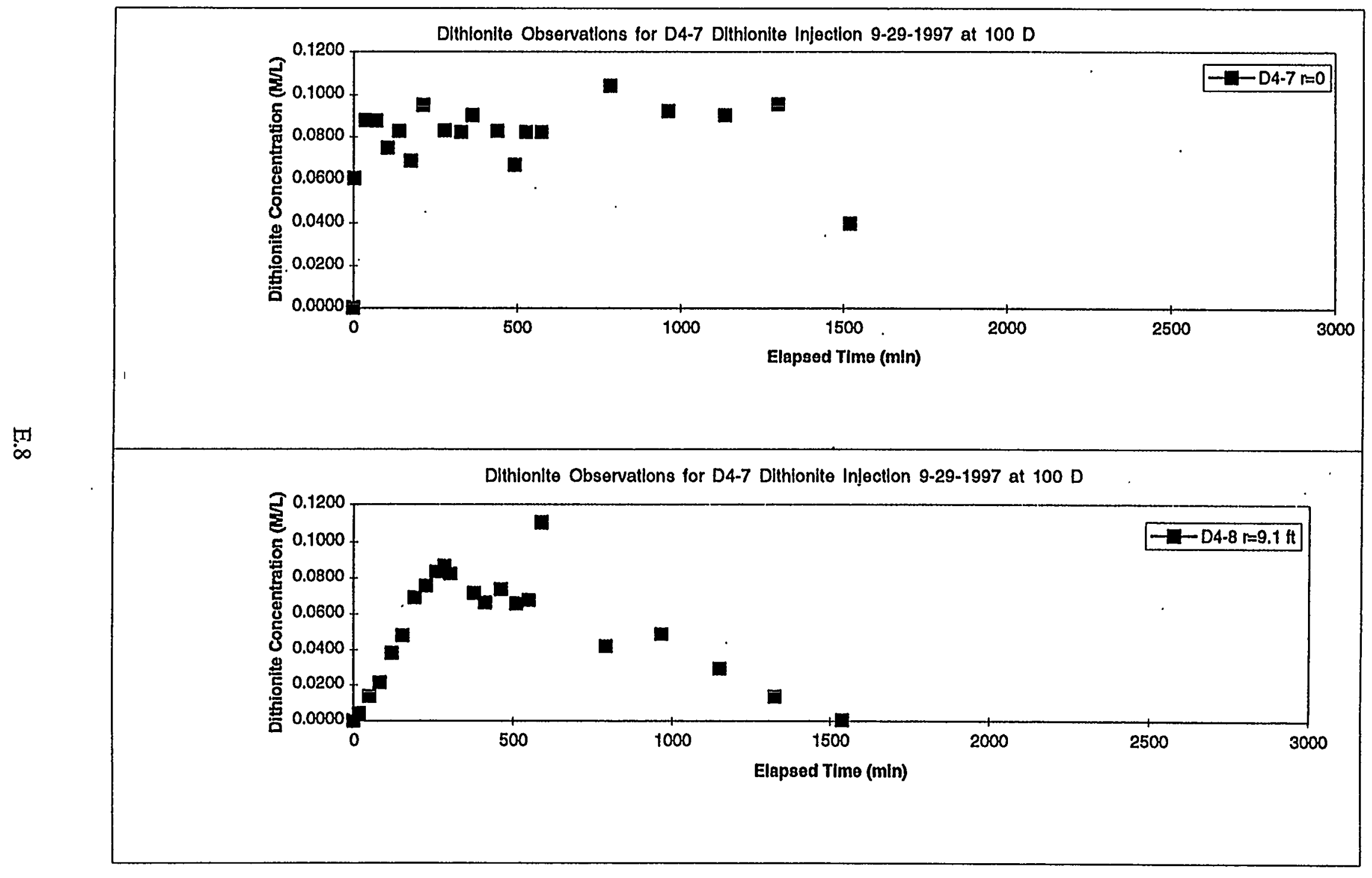




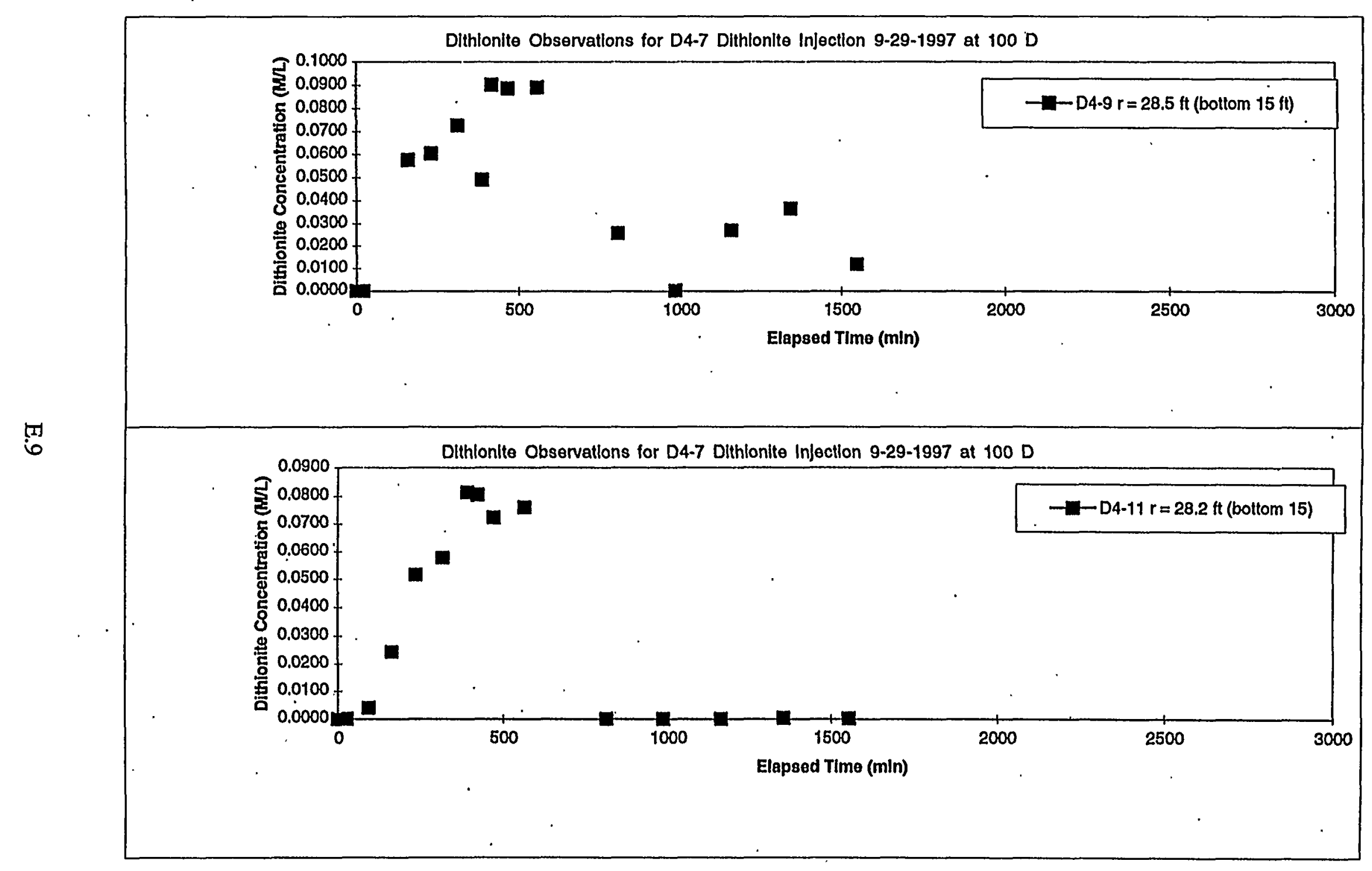




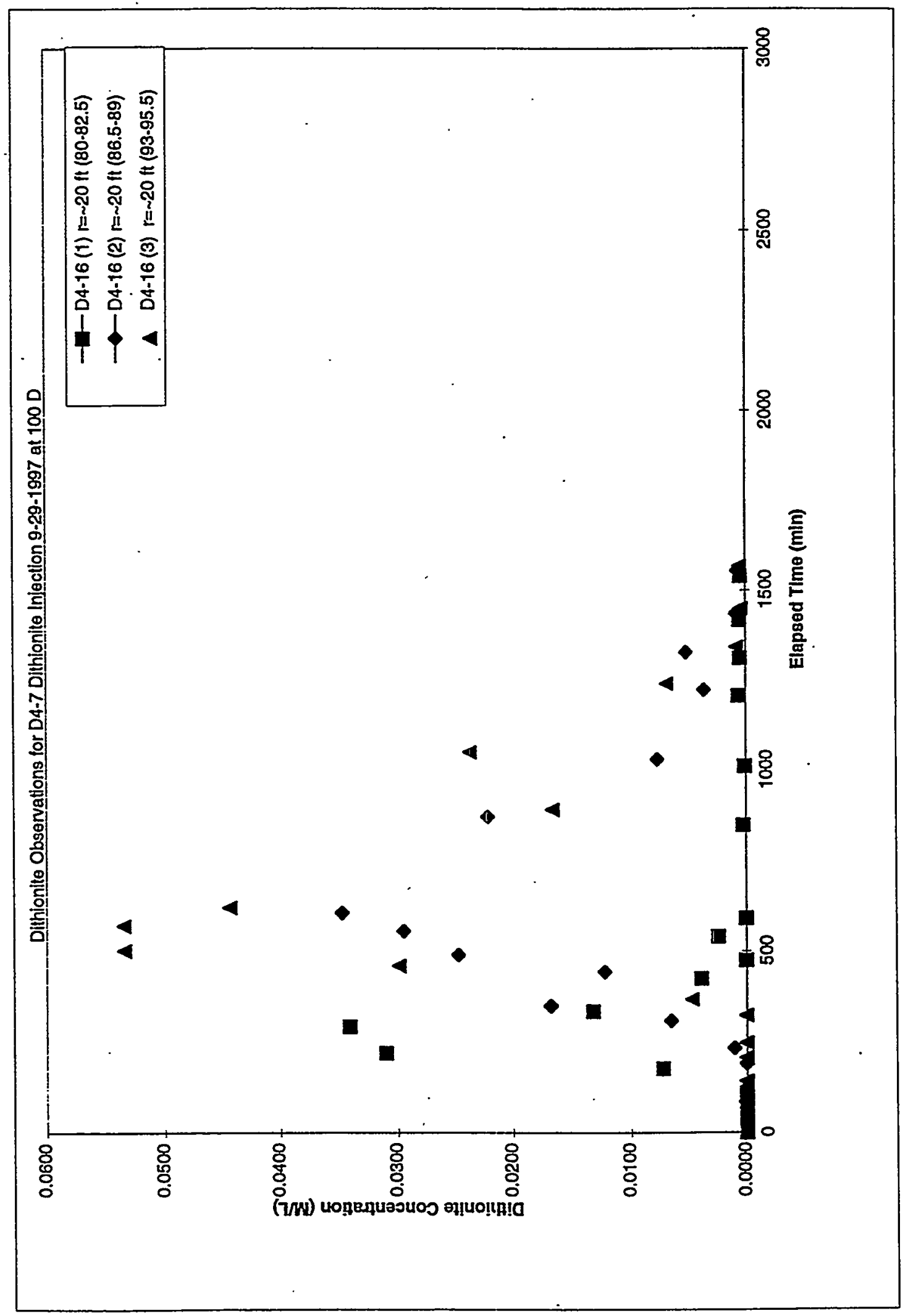

E. 10 


\section{Distribution}

No. of

Copies

\section{Offsite}

2 Office of Scientific and Technical Information

Grover Chamberlain, EM-54

U.S. Department of Energy

Office of Science and Technology

Cloverleaf Building

2400 Century Blvd.

Germantown, MD 20874

Dr. Randal J. Charbeneau

Pickle Research Campus \#119

University of Texas

Austin, TX 78712

Tom Engle, $\mathrm{HAB}$

Department of Civil Engineering

University of Washington

Seattle, WA 98185

Dr. Joseph P. Gould

Georgia Institute of Technology

School of Civil and Environmental

Engineering

790 Atlantic Drive

Atlanta, GA 30332

Barbara Harper

Yakama Indian Nation

P.O. Box 151

Toppenish, WA 98984

Stuart Harris

Confederated Tribes of the Umatilla

Indian Reservation

P.O. Box 638

Pendleton, OR 97801
No. of

Copies
Dr. Alan Moghissi

Institute for Regulatory Science

5457 Twin Knolls Road Ste 312

Columbia, MD 21045

Donna L. Powaukee

Nez Perce Tribe

ERWM Manager

P.O. Box 365

Lapwai, ID 83540-0365

Dr. Vernon C Rogers

Rogers and Associates

P.O. Box 330

Salt Lake City, UT 84110-0330

Philip Washer, DOE-SR

U.S. Department of Energy

Savannah River Operations Office

RFD \#1, Bldg. 703A, Rm E208 North

P.O. Box A

Aiken, SC 29802

James A. Wright, DOE-SR

U.S. Department of Energy

Savannah River Operations Office

RFD \#1, Bldg. 703A, Rm E208 North

P.O. Box A

Aiken, SC 29802

\section{Onsite}

7 DOE Richland Operations Office

D.L. Biancosino

K8-50

J.P. Hanson

K8-50

R.M. Rosselli

K8-50

Distr. 1 
No. of

Copies

K.M. Thompson

$\mathrm{H} 0-12$

A.C. Tortoso

F.R. Serier

J.P. Neath

.5 PHMC Team

G.C. Henckel

H0-09

M.A. Buckmaster

J.G. April

M.J. Graham

V.J. Rohay

3 U.S.EPA

D.A. Faulk

L.E. Gadbois

D.R. Sherwood

3 Washington State Department of Ecology

D.N. Goswami

B5-18

W.W. Soper

B5-18

N.H. Uziemblo

B5-18

Washington Department of Fish

and Wildlife

J.L. McConnaughey

B5-18
No. of

Copies

43 Pacific Northwest National Laboratory

C.C Ainsworth K3-61

S.Q. Bennett K7-90

C.L. Blair K9-14

W.F. Bonner K9-14

K.J. Cantrell K6-81

C.R. Cole K9-36

J.L. Devary K6-96

R.M. Ecker K6-91

J.S. Fruchter (10) K6-96

K.M. Krupka $\quad$ K6-81

W.J. Martin K9-14

J.P. McKinley K3-61

E.M. Pierce K6-96

C.T. Resch K3-61

R.J. Serne K6-81

J.E. Szecsody K3-61

V.R. Vermeul K6-96

R.E. Wildung P7-54

M.D. Williams (10) K9-36

J.M. Zachara K8-96

Information Release (5) K1-06 